UNIVERSIDADE DE SÃO PAULO

FACULDADE DE FILOSOFIA, LETRAS E CIÊNCIAS HUMANAS

DEPARTAMENTO DE HISTÓRIA

PROGRAMA DE PÓS-GRADUAÇÃO EM HISTÓRIA ECONÔMICA

DIEGO DE CAMBRAIA MARTINS

O TRÁFICO DE ESCRAVOS NOS RIOS DA GUINÉ E A DINÂMICA DA ECONOMIA ATLÂNTICA PORTUGUESA

(1756-1807)

São Paulo

2015 
DIEGO DE CAMBRAIA MARTINS

\section{O TRÁFICO DE ESCRAVOS NOS RIOS DA GUINÉ E A DINÂMICA DA ECONOMIA ATLÂNTICA PORTUGUESA (1756-1807)}

Dissertação de mestrado

apresentada ao Programa de PósGraduação em História Econômica da Universidade de São Paulo, sob orientação do Professor Doutor Pedro Puntoni.

São Paulo

2015 
MARTINS, Diego de Cambraia

O Tráfico de Escravos nos Rios da Guiné e a Dinâmica da Economia Atlântica Portuguesa (1756-1807)/Diego de Cambraia Martins - São Paulo, 2015.

151 folhas.

Dissertação de Mestrado em História - Universidade de São Paulo, Programa de Pós-Graduação em História Econômica, 2015.

Orientador: Pedro Luís Puntoni

Título em inglês: The Slavery Trade in Rios da Guiné and the Dynamics os Atlantic Portuguese Economy (1756-1807)

1. Tráfico de Escravos 2.Economia Atlântica 3.Comércio Colonial I.Título 
Para Sika, com amor. 


\section{AGRADECIMENTOS}

Em primeiro lugar agradeço ao CNPq, por ter financiado dois anos de bolsa, o que permitiu que me dedicasse integralmente à minha pesquisa. Agradeço também à Cátedra Jaime Cortesão e ao Instituto Camões, por ter me agraciado com dois meses de bolsa de estágio para pesquisa nos Arquivos e Acervos portugueses: a ida para Lisboa foi fundamental para a escrita dos dois primeiros capítulos dessa dissertação.

Agradeço ao meu orientador Pedro Puntoni por ter me aberto as portas da Universidade de São Paulo, e por todo seu zelo e dedicação durante a realização do meu trabalho. Agradeço duplamente ao Maximiliano Mac Menz: pelo papel de co-orientador e pelo tempo que lhe tomei, como também pela inestimável amizade. À professora doutora Vera Ferlini por todo interesse com minha pesquisa, bem como pelas tantas orientações dadas em sua disciplina e nos congressos da Pós. Gostaria de agradecer também aos professores doutores Ângelo Alves Carrara, da UFJF, Gustavo Acioli Lopes, da UFRPE por toda atenção que sempre tiveram comigo e em acompanhar o desenvolvimento deste trabalho. Ao professor Alexandre Saes, da FEA-USP, pois sua disciplina foi de fundamental importância para amadurecer diversos conceitos que ajudaram nesse trabalho. Por fim, ao professor doutor Rodrigo Ricupero por suas observações e sugestões no exame de qualificação.

Quero agradecer o professor doutor Álvaro Garrido, da Universidade de Coimbra, e a professora doutora Fernanda Olival, os quais eu tive a oportunidade e o prazer de conhecer, além de contar com suas orientações. O bom andamento do estágio de pesquisa em Portugal muito se deu, devido as orientação e a generosidade de ambos os professores. Agradeço também aos colegas Aldair Rodrigues e Angélica Vasconcelos, que muito me auxiliaram antes e durante minha estadia em Lisboa.

Agradeço ao meu grande amigo e irmão Gustavo Dhein, pela amizade construída e que só se fortalece: nossas conversas de toda semana foram fundamentais para que eu pudesse espairecer nos momentos em que a pesquisa parecia não andar. Ao meu amigo André Fillipe, parceiro de História Econômica, das viagens aos Congressos e dos jogos de futebol. Agradeço também ao César Roberto e sua família: começamos a graduação juntos, e seguimos juntos - embora por caminhos diferentes - no mestrado. 
Aos grandes camaradas Felipe Melo, Diógenes Sousa, André Alves, Paulo Tácio, Milton Garcia e Renato Schmidt, amigos de todas as horas.

Agradeço imensamente minha família: minha mãe, Maralice, por me inspirar como educador e historiador. Meus avós Alice e Mosar (in memorian), Maria e Waldemar por fazerem sempre tudo que esteve em seu alcance, para me tornar um homem melhor. Minha irmã Débora e meu cunhado João Rodrigo, por todo apoio e divertimento que me proporcionaram nos momentos complicados no decorrer deste trabalho. Meu pai, Carlos, minha madrasta Giane e meus irmãos Renan e Gustavo, por toda essa boa fase que estamos passando já a alguns anos. A família que me adotou: meus sogros Manoel e Josefa, e minha cunhada Leila por terem me recebido como filho e irmão; e meu cunhado Jefferson, irmão e companheiro de todas as horas.

Por último e mais importante, minha companheira Jéssika: não tenho dúvidas, que não teria chegado até aqui se não fosse por ela. Esteve comigo no momento mais duro do trabalho, suportou as minhas oscilações de humor com muita grandeza e paciência; também teve que lidar com os dois meses de ausência, enquanto estive em Portugal, cuidando de tudo que precisava em nossa futura - agora atual - nova casa. Não conheço mulher como ela. 
A escravatura dos negros havia desde logo triunfado em toda linha.

Edmundo C. Lopes

Um império é sempre improvisado, formado por um equilíbrio ambíguo entre as estratégias centrais, as iniciativas locais e as possibilidades políticas concebidas por poderes antagônicos. Um império constrói-se sobre a conquista, a negociação e o compromisso com diferentes culturas organizacionais e povos.

Francisco Bethencourt 


\title{
RESUMO
}

O trabalho tem por objeto de estudo o tráfico de escravos realizado nos Rios da Guiné, em especial as feitorias de Bissau e Cacheu, que tinham por destino o Estado do GrãoPará e Maranhão. Além do próprio negócio negreiro em África, também avaliaremos os desdobramentos econômicos do tráfico na economia amazônica. O recorte temporal começa no ano de 1756, com o início do funcionamento da Companhia Geral de Comércio do Grão-Pará e Maranhão, empresa de caráter monopolista, que tinha por objetivo o fomento do comércio entre a metrópole e suas diversas possessões ultramarinas no Atlântico. Como marco final optamos pelo ano de 1807, pois com a chegada da Corte em 1808, a colônia mudou seu status passando a ser sede do Reino.

Palavras Chaves: Tráfico de Escravos - Economia Atlântica - Comércio Colonial.

\begin{abstract}
The work is the object of study slave trade conducted in the Rios da Guiné, especially the factories of Bissau and Cacheu, that were destined for the State of the Grão-Pará and Maranhão. In addition to the own slave business in Africa, will also evaluate the economic consequences of trafficking in the Amazon economy. The time frame begins in the year 1756, with the initial operation of the Companhia Geral do Comércio do Grão-Pará e Maranhão, monopolist company, which aimed to promoting trade between the metropolis and its many overseas possessions in the Atlantic. As final milestone we chose the year 1807 , because with the arrival of the Court in 1808 , the colony changed its btatus becoming the seat of the kingdom.
\end{abstract} Keywords: Slave Trade - Atlantic Economy - Trade Colonial. 


\section{ÍNDICE DOS MAPAS}

Mapa I. Arquipélago de Cabo Verde. 20

Mapa II. Os Rios da Guiné. 53

\section{ÍNDICE DAS TABELAS}

Tabela I. Mapa do Comércio da Companhia do Grão-Pará e Maranhão. .28

Tabela II. Gêneros Exportados de Cabo Verde (1756-1778). .40

Tabela III. Exportações de Urzela (1759-1779) - em arrobas.

Tabela IV- Urzela vendida em Portugal e exportada (1758 e 1781) .43

Tabela V. Urzela Caboverdiana Exportada para Lisboa (1790-1806)..... 45

Tabela VI. Exportações de Milho para o Reino (1798-1806). 46

Tabela VII. Panaria enviada aos Rios da Guiné (1758-1782) .48

Tabela VIII. Escravos Embarcados em Cabo Verde e Rios da Guiné (1526-1807...71

Tabela IX. Escravos Desembarcados nos Portos Coloniais da América e nos Portos Metropolitanos (1526-1807).

Tabela X. Escravos Embarcados e Desembarcados divididos por Séculos.

Tabela XI. Escravos Embarcados (1701-1807) .77

Tabela XII. Escravos Desembarcados (1756-1807). 80

Tabela XIII. Escravos Desembarcados divididos pelos portos coloniais portugueses (1701-1807) 81

Tabela XIV. Escravos Introduzidos nos portos da Amazônia (1701-1807) .82

Tabela XV. Porcentagem dos Escravos que era paga com os Têxteis Caboverdianos (1759-177) 84

Tabela XVI. Escravos Introduzidos na Amazônia (1680 - 1755). .93

Tabela XVII. Escravos Introduzidos na Amazônia (1756-1807). 105 
Tabela XVIII. Escravos com origem nos Rios da Guiné, introduzidos na Amazônia (1756-1807)

Tabela XIX. Escravos Introduzidos no Maranhão, oriundos dos Rios da Guiné (17561807)

Tabela XX. Quantidade e Valores Médios dos Gêneros Maranhenses de Exportação (1760-1807)

Tabela XXI. Quantidade e Valores dos Gêneros Paraenses Exportados (1756-1807). 125

Tabela XXII. Escravos Introduzidos no Grão-Pará, oriundos dos Rios da Guiné (17561807)

\section{ÍNDICE DOS GRÁFICOS}

GráficoI- Destinos da Urzela Caboverdiana (1758-1781)........................................ 44

Gráfico II- Participação das Feitorias no Tráfico de Escravos (1526-1807)................ 72

Gráfico III. Participação dos Mercados nas Importações de Escravos (1526-1807).... 74

Gráfico IV. Participação dos Portos Traficantes (1701-1807)......................................78

Gráfico V. Flutuação dos Escravos Embarcados em África (1701-1807).......................78

Gráfico VI. Exportações do Grão-Pará, 1730-1755 (em réis)...................................... 95

Gráfico VII. Dízimos da Terra, 1724-1755 (em réis)..................................................97

Gráfico VIII. Escravos Introduzidos na Amazônia (1756-1807).................................106

Gráfico IX. Comparação entre a origem dos escravos introduzidos na Amazônia no período de monopólio da CGGPM (1756-1778) ) e após a sua extinção (1779-1807) 107 Gráfico X. Comparação entre a origem dos escravos introduzidos na Amazônia após o fim do monopólio da CGGPM, dividido em dois períodos: de 1779 a 1800 e de 1801 a 1807 108

Gráfico XI. Flutuação entre os principais produtos amazônicos exportados e a introdução de escravos (1760-1807) (em toneladas). 111

Gráfico XII. Relação entre a entrada de escravos africanos e os valores das exportações totais da Amazônia (1760-1807) 112

Gráfico XIII. Exportação do Algodão Maranhense (1760-1807) (em arrobas)........... 115 Gráfico XIV. Exportação de Arroz Carolina (1760-1807) (em arrobas) 118

Gráfico XV. Relação entre a produção de arroz e algodão e a entrada de escravos dos Rios da Guiné no Maranhão (1760-1807). .120 
Gráfico XVI. Relação entre as Exportações Totais do Grão-Pará e de Cacau (1756-

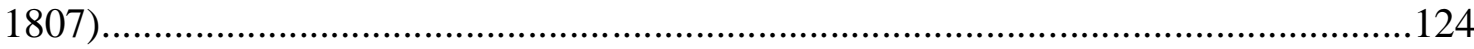

Gráfico XVII. Porcentagem dos Produtos Paraenses Exportados (1756-1807) ..........125

Gráfico XVIII. Relação entre Produção Paraense e Entrada de Escravos (1756-

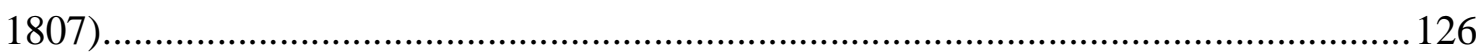




\section{SUMÁRIO}

INTRODUÇÃ O...........................................................................................................01

\section{CAPÍTULO I-O ARQUIPÉLAGO DE CABO VERDE COMO ENTREPOSTO} DO TRÁFICO DE ESCRAVOS NOS RIOS DA GUINÉ...........................................19

1.1- Os portugueses e a colonização de Cabo Verde........................................................19

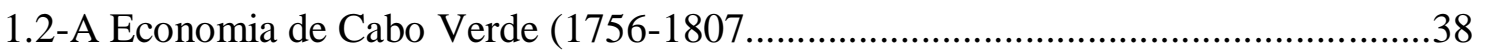

\section{CAPÍTULO II-O TRÁFICO DE ESCRAVOS NOS RIOS DA GUINÉ: AS}

PRAÇAS DE CACHEU E DE SÃO JOSÉ DE BISSAU ......................................52

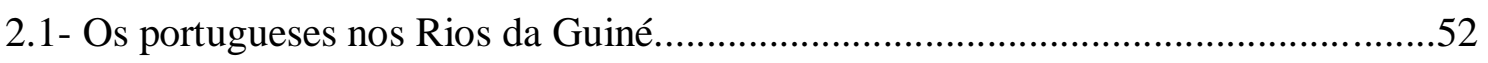

2.2- Tráfico de Escravos nos Rios da Guiné: um estudo quantitativo...............................70

2.3- Os têxteis de Cabo Verde e o Tráfico de Escravos nos Rios da Guiné (1758-

CAPÍTULO III-A ECONOMIA AMAZÔNICA NA LONGA DURAÇÃO (c.1680 -

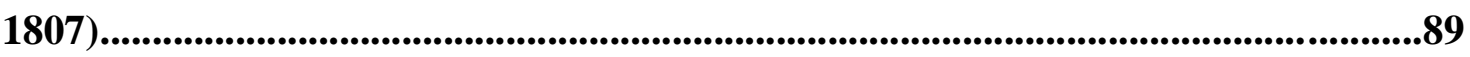

3.1- A Economia no Estado do Grão-Pará e Maranhão (c.1680 - 1755)......................90

3.2- Economia no Estado do Grão-Pará e Maranhão (1756 - 1807)............................100

3.2.1-. As Políticas Pombalinas e o Comércio de Escravos no Estado do Grão-Pará e Maranhão na Segunda Metade do Setecentos. 100

3.2.2- O Tráfico de Escravos nos Rios da Guiné e a Produção Amazônica na Segunda

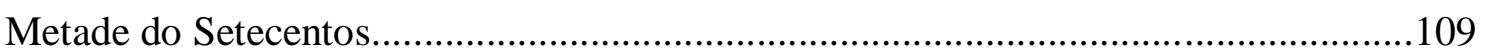

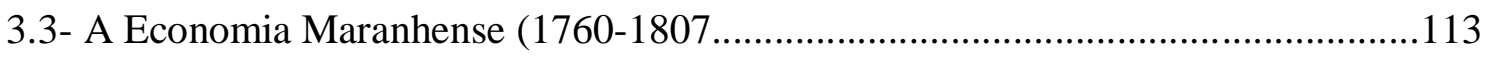

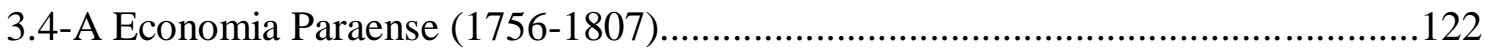

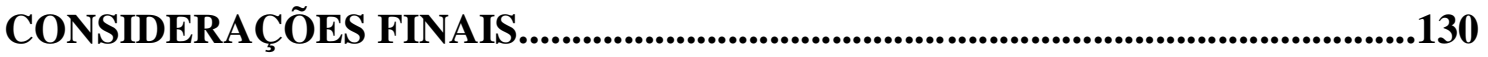

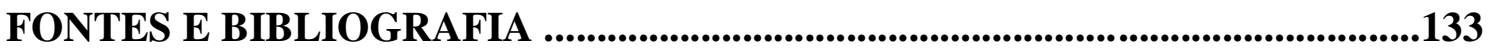

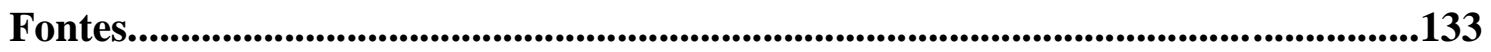

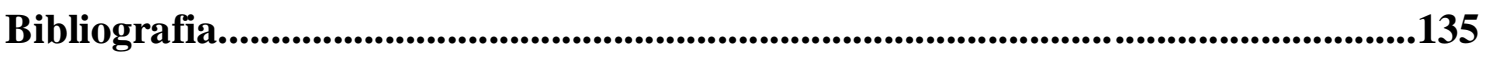




\section{INTRODUÇÃO}

A escravidão esteve instituída na humanidade desde os tempos mais primórdios. A aceitação da desigualdade entre os homens sempre foi muito presente nas mais diversas épocas, nas mais diversas sociedades: da Antiguidade ao mundo Contemporâneo houve escravos e aqueles que o escravizaram. É fato que o conceito de escravidão na Grécia Antiga é completamente diferente da escravidão africana moderna na América; assim como ser escravo em um oikos do mundo homérico é bastante diferente de ser um escravo na produção açucareira no Nordeste do Brasil, no século XVII e XVIII. ${ }^{1}$

Contudo, as camadas dominantes sempre procuraram uma forma de escravizar as camadas despossuídas, seus inimigos, os estrangeiros e assim por diante. Em Portugal, até pelo menos o século $\mathrm{XV}$, os escravos estavam ligados aos trabalhos domésticos e era raro alguém possuir um plantel de mais de cinco escravos. Com a introdução da produção de cana de açúcar na Madeira, Açores e São Tomé, em meados do século $\mathrm{XV}$, a escravidão começou a moldar no que se transformaria na modernidade. São nas ilhas atlânticas então, que vai surgir o conceito de plantation, que posteriormente seria exportado e difundido na América.

Após um desinteresse português pela América de quase três décadas, devido aos esforços estarem voltados ao controle das feitorias comerciais no Oriente, começouse a difundir a produção de cana de açúcar nos novos domínios americanos. Com uma oferta de mão de obra europeia limitada para a produção agrícola em larga escala, alternativas tiveram que ser utilizadas. Destarte, as grandes populações nativas sedentarizadas e estabelecidas no litoral, foram utilizadas como mão de obra compulsória nas plantations. Contudo, a dificuldade em escravizar e os baixos preços pagos pelos nativos, somada a florescente oferta de escravos na costa africana, a preços mais vantajosos para quem negociava escravos, e a experiência bem sucedida nas ilhas atlânticas orientou o comércio de almas da própria África e Europa para a América.

Caio Prado Junior, em seu célebre Formação do Brasil Contemporâneo, argumenta que Portugal, nos primórdios da colonização na América

${ }^{1}$ FINLEY, Moses. A Economia Antiga. Porto: Afrontamento, 1980. passim 
não possuía população para abastecer sua colônia com mão-de-obra. Outro fato é que nenhum colono europeu migraria para os trópicos para o trabalho nas lavouras. A escravidão tornou-se uma necessidade para suprir o grande problema da colonização: a falta de braços para o trabalho nas plantações. Apesar de algumas tentativas de utilizar colonos europeus ou a própria mão de obra nativa, sua substituição pelo africano como alternativa, não demorou muito a acontecer. Para Prado Junior é essa necessidade cada vez maior de mão de obra nas colônias americanas, que fez ressurgir no século XVI, a escravidão - enquanto instituição - na civilização ocidental. ${ }^{2}$

Nesse sentido, para Eric Williams a escravidão foi uma instituição econômica de primeira grandeza. Do ponto de vista histórico, foi um elemento que se enquadrava dentro da nova lógica de exploração e espoliação das camadas de população mais desfavorecidas. Williams ainda afirma que, nos primórdios da colonização na América e Caribe, a Europa estava diante de uma população livre limitada para o cultivo dos gêneros tropicais: a mão de obra africana escravizada surgia, então, como alternativa ao trabalho servil que já existia no Velho Mundo. A escravidão moderna, nesse sentido, mudou as relações sociais no período: o senhor passou a ter o controle absoluto em relação ao escravo, como nunca o tivera nas relações servis. ${ }^{3}$

Jacob Gorender afirma que a escravidão se manifesta como uma instituição fundamental às relações social e de produção. Para o autor o que caracteriza fundamentalmente a escravidão, reside na condição de o africano escravizado ser propriedade de outra pessoa. $\mathrm{O}$ autor sugere ainda que o escravismo, que passou a existir após o século XVI, se dividia em dois tipos diferentes: àquele de caráter patriarcal, que era caracterizado por uma economia de ordem natural; já o escravismo que passou a existir em maior escala na América Colonial, se organizou para a produção de bens que podiam ser comerciados na Europa. ${ }^{4}$

Luiz Felipe de Alencastro sugere, nesse sentido, que a escravidão se transforma em escravismo: um sistema produtivo colonial fundado na escravidão e integrado à economia-mundo. O escravo deixa de executar apenas os trabalhos domésticos, economicamente improdutivos, e passa a produzir bens demandados pelo mercado mundial. O que se assistiu daí foi um comércio transatlântico de escravos africanos que

\footnotetext{
${ }^{2}$ PRADO Jr., Caio. Formação do Brasil Contemporâneo. São Paulo: Brasiliense, 1986. (p. 122).

${ }^{3}$ WILIAMS, Eric. Capitalismo e Escravidão. Rio de Janeiro: Editora Americana, 1975. (p.9 e 10)

${ }^{4}$ GORENDER, Jacob. O Escravismo Colonial. São Paulo: Ática, 1980. (p. 60 e 78)
} 
só cresceu a partir da virada do Quinhentos para o Seiscentos, mantendo uma média de quarenta mil escravos exportados ao ano, durante o século XVIII. A escravidão, então, tornou-se força motriz de uma atividade econômica extremamente vantajosa aos homens de negócio, apesar dos riscos da travessia. ${ }^{5}$ E entender o tráfico de escravos, do ponto de vista de uma atividade economicamente lucrativa é um dos pontos de análise deste trabalho. Assim como, observar seus estímulos na Amazônia Portuguesa.

Falando da organização do comércio negreiro, o debate historiográfico está bastante consolidado. Pode-se assim dizer, que existem duas teses dominantes sobre como esse tráfico atlântico de escravos se articulou: o da triangularidade, com destaque para a historiografia anglo-saxã; e o da bipolaridade - ou bilateralidade - fruto das correntes historiográficas revisionistas, teses essas que possuem bastante força na historiografia brasileira. A seguir serão pontuados alguns aspectos, os principais argumentos e autores de ambas as interpretações.

O autor que consagrou o conceito de comércio triangular foi o já citado, Eric Williams.Em Capitalismo e Escravidão o autor argumenta, grosso modo, que a metrópole era responsável pelo fornecimento das manufaturas e das embarcações para o transporte; do continente africano, deveriam vir os escravos para servir de mão de obra; e por fim, das colônias no Novo Mundo os gêneros tropicais que serviriam de matériaprima colonial. A triangularidade funcionava da seguinte forma: a embarcação imbuída no comércio triangular tinha como início de sua viagem a metrópole, de onde partia com produtos manufaturados; estes eram trocados por escravos em África, que eram remetidos para a América para o trabalho nas lavouras; da relação entra a lavoura e escravos, se remetiam os produtos coloniais com destino à metrópole. ${ }^{6}$

O comércio triangular, nesse sentido, proporcionou grande estímulo para a indústria inglesa. Estímulos esses, que eram decorrentes dos "três lados" do triângulo comercial: os escravos eram adquiridos com os produtos manufaturados, de origem inglesa, com lucro. Trabalhando nas plantações de maneira compulsória, possibilitavam a exportação de gêneros tropicais, que ao mesmo tempo, proporcionava o surgimento de novas indústrias na metrópole. E esses mesmos escravos, agora realocados na América, juntamente com seus senhores acabaram por criar um novo mercado consumidor para a

\footnotetext{
${ }^{5}$ ALENCASTRO, Luiz Felipe de. O Trato dos Viventes: Formação do Brasil no Atlântico Colonial. São Paulo: Cia das Letras, 2000. (p.32)

${ }^{6}$ WILLIAMS. Op. cit. (p.57)
} 
Inglaterra e "os lucros obtidos forneceram um dos principais fluxos dessa acumulação de capital na Inglaterra que financiou a Revolução Industrial."

No que toca a historiografia brasileira, a tese da triangularidade pode ser observada em Portugal e Brasil na Crise do Antigo Sistema Colonial, de Fernando Novais. O autor entende o tráfico de escravos como uma engrenagem da colonização, aos moldes mercantilistas. O comércio negreiro tornou-se setor comercial de grande importância, no âmbito das relações coloniais, ao mesmo tempo em que garantia e promovia a acumulação primitiva na metrópole. Ou seja, “a acumulação gerada no comércio de africanos [...], fluía para a metrópole, realizavam-na os mercadores metropolitanos, engajados no abastecimento dessa mercadoria". ${ }^{8}$ Contudo, no decorrer de sua obra, Novais vai apontar para um ramo do tráfico que surgiu e passou ocorrer diretamente entre a América Portuguesa e os portos traficantes em África e que o autor justifica como "o exclusivo naufragando, o pacto colonial se rompendo, o sistema entrando em crise". 9

Em relação ao surgimento de uma rota realizada diretamente entre a América Portuguesa e África, bem como o surgimento de traficantes estabelecidos nas praças coloniais, já havia sido destacado por Luiz Viana Filho em O Negro na Bahia, obra datada da década de 1940. ${ }^{10}$ Mas é em Fluxo e Refluxo, de Pierre Verger, em que haverá um estudo mais aprofundado das conjunturas do tráfico de escravos que ocorria entre o Golfo do Benin e a Bahia, e que permitiu uma estreita relação entre as duas margens do Atlântico, e fez-se com que costumes e tradições atravessassem o oceano de lado a outro, agregando ao cotidiano baiano traços do modo de vida africano e vice-versa.

Mais do que mostrar o estreitamento dos laços brasileiros e africanos, a obra de Verger é fundamental para entender a dinâmica do tráfico de escravos como um negócio altamente rentável. Para Verger, o tráfico possibilitou a formação de uma elite mercantil luso-baiana, que ascendeu com a compra e venda de escravos, bem como com o fretamento da carga viva. O serviço de frete ligado ao tráfico foi um setor que

\footnotetext{
${ }^{7}$ WILLIAMS. Op.cit. (p.58)

${ }^{8}$ NOVAIS, Fernando. Portugal e o Brasil na Crise do Antigo Sistema Colonial. São Paulo: Hucitec, 1995. (p.105)

${ }^{9}$ Idem. (p.198)

10 VIANA FILHO, Luiz. O Negro na Bahia. Rio de Janeiro: Nova Fronteira, 1988 Apud ACIOLI, Gustavo \& Maximiliano Mac Menz. Tráfico e Historiografia: notas e propostas para o estudo do comércio luso brasileiro de escravos (sec. XVII-XVIII).(p.6) Working paper de apresentação do Colóquio Internacional Economia e Colonização nas dimensões do Império Português, Cátedra Jaime Cortesão, 2008. A versão utilizada foi cedida gentilmente pelo professor Maximiliano Max Menz.
} 
impulsionou financeiramente os donos de embarcações, que prosperam tanto quanto os comerciantes. $\mathrm{O}$ autor sugere que a ascensão dessa elite mercantil colonial, gerou uma rivalidade com os negociantes lisboetas. Estes se viram prejudicados do ponto de vista financeiro, já que só comerciantes lusos-baianos atravessavam o negócio.Apesar de várias tentativas para cercear esses comerciantes estabelecidos na Bahia, eles continuavam a traficar em África por possuírem acesso - ou muitas vezes diretamente ligados - à produção do tabaco. ${ }^{11}$

Para Verger, o papel fundamental que terá o tabaco baiano no comércio de escravos é o ponto-chave de sua investigação. O tabaco seria o principal produto utilizado para adquirir escravos e aqui podem surgir algumas questões importantes: o tabaco não faz parte da lista de produtos coloniais pertencentes ao exclusivo metropolitano? Por que o tabaco baiano e não o tabaco produzido em outras regiões da América?

O tabaco era, de fato, um dos produtos que sofriam o estanco por parte da Coroa Portuguesa.Mas há de se destacar que do seu beneficiamento resultava em três tipos de produto: o fumo de primeira, segunda e terceira categoria. Os fumos de primeira e de segunda categoria eram obrigatoriamente enviados a metrópole, enquanto que o de terceira deveria ser consumido na própria colônia. Como o de terceira categoria se estragava com muita facilidade, era embebido em uma espécie de melaço para aumentar sua durabilidade, o que lhe dava um sabor e um aroma agradável. E aqui está a resposta para a segunda questão: a introdução desse tipo de fumo, na Costa da África, acabou agradando o mercado local e conseqüentemente gerando uma demanda. O fumo baiano tornou-se essencial, pois nenhuma outra metrópole européia conseguiu reproduzi-lo com a mesma qualidade. ${ }^{12}$

Em conformidade com a interpretação da existência de uma bilateralidade entra Brasil e África, procurando refutar as contribuições de Novais e a idéia de triangularidade proposta por Williams, temos a obra Em Costas Negras de Manolo Florentino. Para o autor, sua análise se baseia no argumento de que "não eram suficientes as explicações disponíveis sobre a enorme migração compulsória que

\footnotetext{
${ }^{11}$ VERGER, Pierre. Fluxo e refluxo: do tráfico de escravos entre o Golfo do Benin e a Bahia de Todos os Santos. Salvador: Corrupio, 2002. (p. 150)

${ }^{12}$ Idem. (p.155)
} 
durante mais de três séculos uniu a África e o Brasil." ${ }^{13}$ A partir dessa premissa, Florentino procura demonstrar a atuação do comerciantes estabelecidos na praça do Rio de Janeiro e a importância de seu crédito, em toda a dinâmica mercantil de compra, transporte e venda dos escravos. Tal fato serve de argumento, para corroborar sua tese de uma suposta insuficiência do capital metropolitano, para atender a demanda de mão de obra existente na América.

Tendo em conta o fortalecimento dos comerciantes cariocas, devido ao trato de escravos, Florentino tentou traçar o perfil desses homens negócio. Para isso buscou mostrar como atuavam no tráfico, bem como se enquadravam dentro da estrutura social e política do Rio de Janeiro. Nesse sentido, constatou que o comércio de almas era altamente lucrativo e permitia uma ascensão financeira desses grupos mercantis estabelecidos nas colônias. Pode-se perceber então, que o tráfico seria elemento fundamental para a acumulação de capital por parte dos traficantes estabelecidos no Rio de Janeiro, e que formaram uma "elite mercantil fluminense" que modificou completamente as dinâmicas econômicas, sociais e políticas do que se tornaria o Brasil. Para o autor o tráfico de escravos é "o mais importante setor de acumulação endógeno à colônia" suplantando até mesmo a economia agrícola de exportação baseado no açúcar. ${ }^{14}$ Sendo assim, sua interpretação procura revisar a historiografia tradicional, buscando novas interpretações do sistema escravista que se constituiu na América Portuguesa.

Nesse mesmo caminho, reforçando a tese da bilateralidade, temos $O$ Trato dos Viventes, de Luiz Felipe de Alencastro. Seu argumento principal é que o sucesso dos produtos coloniais na África Central, como a mandioca, o tabaco e a cachaça, fizeram com que as duas margens atlânticas fossem cada vez mais próximas: a dinâmica formada no Atlântico Sul remetia produtos coloniais para a África, e em contrapartida trazia escravos no caminho inverso.Os produtos coloniais, segundo Alencastro, garantiram um fluxo contínuo de mão de obra escrava para a América Portuguesa, o que contribuiu de forma significativa para a expansão da produção açucareira, bem como o sucesso da exploração colonial baseadas nas plantations. ${ }^{15}$

\footnotetext{
${ }^{13}$ FLORENTINO Manolo. Em Costas Negras: uma história do tráfico de escravos entre a África e o Rio de Janeiro (séculos XVIII e XIX). Rio de Janeiro: Arquivo Nacional, 1995. (p.10)

${ }^{14}$ Idem. (p.210)

${ }^{15}$ ALENCASTRO. Op. Cit. passim
} 
Para Alencastro, essa ligação entre Angola e Brasil começaria com a influência de uma elite brasílica, na administração régia de Angola após o sucesso da expedição de reconquista coordenada por Salvador Correia de Sá. Demonstra também como a cachaça, assim como o tabaco, passou a ter importância no mercado africano,custeando boa parte das transações mercantis de compra de escravos, segundo o autor. Tal argumento corroboraria a tese da bilateralidade mercantil entre Brasil e Angola, mostrando a influência e proeminência dos negociantes estabelecidos nas praças coloniais do Brasil em território africano. Nesse sentido, nas suas palavras, "uma complementaridade econômica costura a África ao Brasil". ${ }^{16}$

Por outro lado, existem autores que sugerem que outros modelos de negócio em relação ao tráfico não podem, e nem devem, ser ignorados. Leonor Freire Costa, por exemplo, sugere uma diferenciação fundamental a ser feita: o tráfego e o tráfico. ${ }^{17}$ Nesse sentido, pode-se entender o financiamento e o transporte como duas operações distintas na dinâmica da economia atlântica. Maximiliano Mac Menz, no artigo "As Geometrias do Tráfico: o comércio metropolitano e o tráfico de escravos em Angola", sugere que no caso angolano, por exemplo, somente o tráfego podia ser considerado bipolar, entretanto sem o capital português era impossível adquirir as demais fazendas necessárias para a efetivação dos negócios em África.

Nesta mesma linha Gustavo Acioli Lopes, em sua tese de doutoramento intitulada Negócio da Costa da Mina e Comércio Atlântico, procura estabelecer dois ramos do tráfico de escravos: o primeiro seria aquele que a historiografia convencionou chamar de bipolar, feito diretamente entre os portos americanos e africanos. Acioli aponta que o tráfico bipolar se fortaleceu com a diminuição da força econômica portuguesa, decorrente de problemas enfrentados desde a Restauração. Com isso os mercadores das praças coloniais estabeleceram uma rota de tráfico utilizando produtos coloniais de grande penetração no mercado africano: a cachaça e o tabaco. Outro fator, que neste sentido dialoga com a obra de Alencastro, foi a premiação aos súditos que combateram os holandeses, com a nomeação de cargos administrativos em Angola, principalmente ao de Governador.

\footnotetext{
${ }^{16}$ ALENCASTRO. Op. Cit. (p.30)

17 COSTA, Leonor Freire. O Transporte no Atlântico e a Companhia Geral do Comércio do Brasil. Lisboa: CNCDP, 2002 Apud ACIOLI \& MENZ. Tráfico e Historiografia. Op. Cit. (p.12)
} 
Entretanto, mesmo com o fortalecimento do tráfico bipolar, Acioli destaca que o modelo triangular não pode, e nem deve, ser ignorado.Segundo o autor, isso se deve ao fato de que estes mercadores reinóis obtinham vantagens fiscais sobre os escravos introduzidos na América Portuguesa; além disso, tinham mais facilidades de adquirir as demais fazendas necessárias ao tráfico de escravos como armamentos e têxteis a preços muito mais baixos do que os estabelecidos nas praças coloniais, que tinham de adquirilos nas feitorias européias estabelecidas em África, a preços bem menos competitivos. ${ }^{18}$ Em relação aos produtos coloniais envolvidos no tráfico, bem como a participação dos negociantes estabelecidos nas praças coloniais, Acioli destaca uma supervalorização do tabaco por parte da historiografia - e aí podemos colocar os outros produtos coloniais - mostrando que o tabaco é apenas um dos produtos necessários para o negócio. Ou melhor: um produto que garantia vantagens ao mercador súdito português.

No entanto, no século XVIII, dentre os mercadores brasílicos, o produto importante no trato foi o ouro contrabandeado. Este ouro permitia a compra das diversas mercadorias que compunham o cesto de produtos que interessavam ao mercado africano. Estes eram adquiridos dos comerciantes estrangeiros, estabelecidos nas feitorias africanas. Apesar de todo o esforço "brasílico" em controlar o tráfico de escravos, Acioli mostra que foi evidente a participação metropolitana, cujos negociantes tentavam de todas as formas controlar o trato de escravos e o comércio com a África. Isso pode ser facilmente demonstrado com a criação de diversas Companhias de comércio monopolistas pela Corte Portuguesa ${ }^{19}$.

Outro fato interessante demonstrado por Acioli, é que mesmo na colônia, havia um grande número de mercadores reinóis atraídos pela extração aurífera. Por não terem recursos suficientes para se manterem nos centros mineradores, esses comerciantes se fixavam em outras praças, como o Recife, para se estabelecerem no tráfico de escravos. Assim o autor aponta para duas direções: demonstra a força do capital reinol no tráfico de escravos; e desmistifica a grande importância dada aos produtos coloniais - a jeribita e o tabaco - no comércio com a África, importância esta que permitiria uma

\footnotetext{
${ }^{18}$ ACIOLI, Gustavo. Negócio da Costa Mina e Comércio Atlântico - tabaco, açúcar, ouro e tráfico de escravo: Pernambuco (1654-1760). USP: São Paulo, 2008 - tese de doutoramento. (pp. 31-37)

${ }^{19}$ Idem. (pp.60-67)
} 
predominância dos traficantes "brasílicos" sobre os reinóis, por terem mais acesso a estes produtos. $^{20}$

O surgimento de uma rota bipolar, nesse sentido, se deu em uma conjuntura de crise econômica portuguesa, em que Portugal se estabeleceu como semi-periferia, dentro da economia-mundo. Durante o século XVII, o Império Português perdeu possessões no Índico que eram importantes para que se abastecessem de produtos para o tráfico, como os têxteis. Portugal poderia agir como Castela, abastecendo-se de escravos através de asientos, mas buscou uma alternativa interna: reinóis estabelecidos na colônia se encarregaram de manter o tráfico, utilizando-se de gêneros da terra, junto com outras mercadorias demandadas na África. ${ }^{21}$

No artigo "Resgate e Mercadorias: uma análise comparada do tráfico lusobrasileiro de escravos em Angola e na Costa da Mina (século XVIII)"22, Acioli, em parceria com Maximiliano Mac Menz, já sugeria este tipo de análise. Neste trabalho, os autores reforçam a idéia de diferenciação entre o tráfego e o tráfico, proposta por Leonor Freire Costa. O financiamento e o transporte são duas operações distintas no circuito econômico. Enquanto os navios portugueses atuariam no transporte de mercadorias utilizadas no financiamento do tráfico, as embarcações coloniais se encarregariam do transporte destes escravos. Essa diferenciação fica bastante evidente em Angola, e menos na Costa da Mina, onde se confundiam. ${ }^{23}$

O tráfico português, como já observado é ligado a diversos circuitos da economia-mundo: Ásia, África, América e Europa. O tráfego pode ser considerado bipolar. Entretanto, sem o capital português ou ouro contrabandeado, era impossível adquirir os demais produtos necessários para a efetivação dos negócios. Os autores procuram relativizar a importância dos produtos coloniais no comércio negreiro com Angola, devido ao fato desta separação entre tráfego e tráfico. Revisando os números da cachaça, constataram que esta ocupou um papel pequeno no que diz respeito à participação na compra de escravos. Sugerem que, em Angola, o financiamento se dava

\footnotetext{
${ }^{20}$ Idem. (pp. 83-84)

${ }^{21}$ ACIOLI. Op. Cit. (pp. 87-88)

${ }^{22}$ ACIOLI, Gustavo \& MENZ, Maximiliano M. Resgate e Mercadorias: uma análise comparadado Tráfico Luso-Brasileiro de Escravos em Angola e na Costa da Mina (Século XVIII). In: Afro-Ásia, núm. 37, 2008.

${ }^{23}$ ACIOLI, Gustavo e MENZ, Maximiliano M. Op. Cit. (pp. 11-13)
} 
por meio dos produtos europeus, trazidos pelos portugueses, já que estes possuíam o monopólio comercial da região.

Já na Costa da Mina, onde os lusos eram obrigados a concorrer com as demais nações européias, o tabaco era utilizado como mercadoria diferencial dos comerciantes luso-brasileiros; e o ouro, utilizado para a compra das demais fazendas necessárias para o trato. Mais uma vez, aponta-se para duas mercadorias que eram fundamentais para a efetivação dos negócios em África. ${ }^{24}$ Grosso modo, observamos que os autores sugerem a existência de uma triangularidade do ponto de vista do financiamento do negócio, sem descartar a existência de embarcações que realizava o "tráfico triangular clássico". Acioli e Menz enxergam ainda, para uma atividade bipolar, ligado ao transporte de escravos, onde o capital metropolitano também tinha força. Propõe ainda uma supervalorização dos produtos coloniais no negócio negreiro pela historiografia revisionista.

Os produtos coloniais, como a jeribita, ocupavam um papel secundário, configuram apenas uma vantagem na hora de negociar com produtos que as outras nações européias não possuíam, sobretudo no caso do tabaco. O ouro seria peça fundamental, pois sem ele, não se comprariam outras mercadorias necessárias ao trato. Mesmo com o contrabando, não é possível confirmar uma autonomia colonial, ou "brasílica”. Afinal Acioli e Menz afirmam que boa parte dos negociantes estabelecidos nas praças coloniais, envolvidos no tráfico, eram reinóis; estes, após uma temporada na colônia, voltavam ao Reino onde continuavam a atuar como negociantes, financiando sobretudo o comércio Atlântico.

A questão, no entanto, não se encontra apenas nas mercadorias necessárias para a se realizar o tráfico de escravos. Dizem respeito, sobretudo nas relações sociais por detrás delas e pelas quais o tráfico de escravos se organizou. Sendo assim, a pesquisa parte do pressuposto de que o tráfico de escravos português estava diretamente relacionado aos ajustamentos da economia-mundo européia. As diferentes regiões onde se realizavam o trato negreiro possuíam suas especificidades, estas diretamente relacionadas com o enquadramento das metrópoles - neste caso, Portugal - na

\footnotetext{
${ }^{24}$ ACIOLI, Gustavo e MENZ, Maximiliano M. Resgate, mercadorias e economia-mundo. Op. Cit. (pp. 20-23)
} 
economia mundo e das condições oferecidas pelo próprio mercado africano, que demandava certos produtos específicos para realização do tráfico.

$$
* * *
$$

Para contribuir um pouco mais com esse debate, este trabalho tem por objetivo investigar o tráfico de escravos nos Rios da Guiné, especialmente para os portos amazônicos. O recorte temporal começa no ano de 1756, com o início do funcionamento da Companhia Geral de Comércio do Grão-Pará e Maranhão, empresa de caráter monopolista, que tinha por objetivo o fomento do comércio entre a metrópole e suas diversas possessões ultramarinas no Atlântico. Como marco final, optamos pelo ano de 1807, pois com a chegada da Corte Portuguesa em 1808, a colônia mudou seu status, passando a ser sede do Reino e modificando as dinâmicas comerciais atlânticas.

O intuito é procurar rediscutir o papel do tráfico na economia atlântica portuguesa. Com isso, pretende-se avaliar a importância desse ramal traficante, a partir dos dados coletados no trabalho com as fontes e assim, identificar seu tamanho no conjunto do Atlântico português. Particularmente pretende-se investigar os impactos do tráfico para a economia amazônica colonial - bem como em Portugal - analisando as cargas de retorno, procurando revelar a associação entre fornecimento de escravos e exportação de gêneros tropicais. Para isso foi analisado, fichado e tabulado um expressivo corpus documental; os fundos, séries, coleções e base de dados mobilizados para a escrita deste trabalho, serão discutidos a seguir.

\section{Das fontes e métodos}

Em relação ao estudo referente ao tráfico de escravos, os dados coletados foram extraídos do sítio Trans-Atlantic Slave Trade Database ${ }^{25}$. É banco de dados que reúne informações de cerca de trinta e cinco mil viagens realizadas por embarcações traficantes; estas foram responsáveis por deslocar cerca de doze milhões de indivíduos da África para as Américas e, em menor escala para Europa. O banco de dados teve como primeiro esforço, o trabalho de Hebert Klein e outros historiadores que começaram a coletar dados sobre o comércio negreiro, decodificá-los e datilografá-los. A partir da década de 1970, outros historiadores se juntaram ao projeto e ao fim dos

\footnotetext{
${ }^{25}$ Disponível em: slavevoyages.org
} 
anos de 1980, já haviam sido catalogadas onze mil viagens. Até então, o trabalho vinha se realizando por conta própria dos pesquisadores.

A partir de 1990, os trabalhos de pesquisa realizados por David Eltis, Stephen Behnrendt e David Richard encorparam ainda mais o banco de dados que finalmente receberiam fomento da National Endowment for the Humanities e da Fundação Mellon após trabalho liderado pelo professor do Instituto de Pesquisas Afro-Americano de Harvard, Hanry L. Gates. Os anos 1990 contaram com muitos esforços, vindos dos quatro cantos, inclusive do Brasil - com Manolo Florentino e Roquinaldo Ferreira graças aos aportes financeiros recebidos; e em 1999, 60\% dos dados disponíveis hoje já estavam coletados e catalogados. A construção do website de consulta pública foi possível apenas em 2006, graças a um prêmio concedido pela Universidade de Emory, nos EUA. Contando mais uma vez com subsídios financeiros da National Endowment for the Humanities, mas principalmente do Instituto de Pesquisas Afro-Americano de Harvard foi possível a criação e disponibilização do banco de dados na rede mundial de computadores. Hoje o projeto conta com mais de quarenta pessoas em sua equipe técnica e mais de cinqüenta pesquisadores que colaboram com a coleta de dados. ${ }^{26}$

Essa fonte, porém, apresenta algumas limitações no que se refere aos números e informações disponibilizados. No que diz respeito aos dados sobre Angola, por exemplo, encontram-se algumas discrepâncias com os números oferecidos pelo sítio; aparecem algumas incongruências, quando cruzados com documentos contidos nos arquivos históricos portugueses, bem como com os números publicados na obras que discutem o tráfico angolano. Entretanto, para os dados referentes aos Rios da Guiné, os números parecem fiáveis. Os números publicados por António Carreira e Manuel Nunes Dias, para o período de atuação da Companhia de Comércio do Grão-Pará e Maranhão, quando cruzados com os disponibilizados pelo Database aparentam ser seguros. Em Lisboa, no Arquivo Histórico Ultramarino encontramos um Mapa Geral do Comércio da Companhia, em que os números para o tráfico de escravos são bastante fidedignos com os do Database.

Durante os dois anos de Iniciação Científica e nos três de mestrado, não encontramos nenhuma obra, que discutisse mais amplamente o tráfico de escravos na região dos Rios da Guiné. Normalmente encontramos algumas discussões sobre o

\footnotetext{
${ }^{26}$ Idem.
} 
assunto, em algumas obras mais gerais sobre o comércio de escravos, sobre o arquipélago de Cabo Verde ou sobre a questão da mestiçagem na região. Nos documentos avulsos, sejam eles da Guiné ou do Grão-Pará e Maranhão, também não foi encontrado nada muito substancial em relação aos números de escravos. Encontramos dez mapas de importação para os anos de 1775 a 1777, 1779, 1782, 1785, 1791, 1793 a 1796 e 1801. Não é necessário dizer, que com uma documentação fragmentada, não seria possível construir uma série segura para análise; entretanto, serviu para atestar que os números do Database são válidos para o tráfico nos Rios da Guiné.

Em um segundo momento, realizamos o trabalho de pesquisa nos Documentos Avulsos do Arquivo Histórico Ultramarino. Compreende toda a documentação manuscrita, que pertencem ao fundo do Conselho Ultramarino. Este fundo reúne grande volume de documentação produzida pelas instituições da administração central portuguesa e que tratavam de muitos assuntos referentes à gestão das possessões ultramarinas portuguesas: as mais importantes seriam o próprio Conselho Ultramarino, e também a Secretaria de Estado da Marinha e Ultramar. A investigação se deu de duas maneiras distintas: in loco, no Arquivo Histórico Ultramarino; e via digital, pelo Projeto Resgate Barão de Rio Branco.

Durante o estágio de pesquisa nos Arquivos e Acervos de Portugal, em relação aos papéis avulsos da administração portuguesa na Guiné e em Cabo Verde, tivemos acesso a um total de 47 caixas: 35 delas do arquipélago caboverdiano e as outras 12 das feitorias portuguesas na região dos Rios da Guiné, sobretudo Cacheu e Bissau. Foram analisados pouco mais de 3.000 documentos, que tratavam basicamente das correspondências entre governadores e a Corte, memórias, mapas das tropas, mapas das exportações, avisos, pareceres, resoluções e alvarás do Conselho Ultramarino, cópias de Ordens Régias, dentre outras que permitiram entender o funcionamento da administração portuguesa neste complexo formado por Cabo Verde e Guiné.

Além disso, através desse corpo documental, foi possível começar a compreender o enquadramento dessa região, no âmbito do Império Português, para o período compreendido entre 1750 até aproximadamente 1808. Período esse, quando passou a ser a principal fornecedora de escravos para a Amazônia. A metodologia de trabalho, envolvida na pesquisa com essas fontes, se deu principalmente através da leitura e fichamento da documentação fundamental ao trabalho, bem como a 
digitalização das mais importantes e pontuais à pesquisa através de fotografias. Para àquelas que haviam dados quantitativos, foram todos tabulados em planilhas, para a construção de séries, como por exemplo a série do preços dos escravos comercializados pela Companhia de Comércio.

Já as fontes que se encontravam digitalizadas pelo Projeto Resgate Barão de Rio Branco, diziam respeito aos mesmos Documentos Avulsos: mas estavam relacionados ao Grão-Pará e o Maranhão. Do mesmo modo, que pudemos enquadrar os Rios da Guiné e Cabo Verde no âmbito do Império, os papéis avulsos das capitanias amazônicas permitiram integrar a colonização amazônica - desde o fim do século XVII, até o início do XIX - no plano administrativo da Coroa Portuguesa. Esses documentos, contudo, não são importantes, apenas do ponto de vista qualitativo. Encontramos documentação quantitativa, que depois de tabuladas e seriadas em planilhas, resultaram na construção de várias bases de dados referentes a economia amazônica, entre os anos de 1730 e 1807. O cruzamento desses dados foi peça-chave para avaliar a relevância de cada capitania para economia atlântica portuguesa, bem como perceber os principais produtos exportados da pela região. Mas mais relevante para o trabalho, foi quando transpomos esses dados com os coletados referentes ao tráfico de escravos, em que pudemos avaliar os impactos causados na economia amazônica, pela introdução regular da mão de obra africana.

Outra rica fonte foi de enorme importância para nosso trabalho. O notável trabalho de António Carreira, nos dois volumes de A Companhia Geral do Grão-Pará e Maranhão, em que publicou a documentação mais relevantes e todo o movimento comercial da empresa pombalina no período em que atuou em Cabo Verde, Rios da Guiné e na Amazônia Portuguesa. Destarte, apesar de não conter uma análise mais aprofundada dos números publicados, é preciso destacar a capacidade de Carreira em mobilizar esforços para tabular a enorme quantidade de dados em uma só obra. Não seria possível para nós, nos dois meses em que estivemos em Portugal, darmos conta de tamanha documentação contida nos 217 Livros do Fundo da Companhia de Comércio do Grão-Pará e Maranhão, existentes no Arquivo Nacional da Torre do Tombo. ${ }^{27}$

\footnotetext{
${ }^{27}$ CARREIRA, Antônio. A Companhia Geral do Grão-Pará e Maranhão. Lisboa: Nacional, 1988.
} 
Com esses dados disponibilizados por Carreira, foi possível constatar se os dados referentes às exportações amazônicas, seriados a partir da documentação avulsa eram fiáveis para os anos de funcionamento da Companhia. Mostrando-se confiáveis, trouxeram segurança para a nossa análise dos dados após o fim do monopólio em 1778. Também foi importante, para corroborar os dados relativos ao tráfico de escravos do Database, como já mencionado. Sem contar a sua validade para constituir a economia exportadora de Cabo Verde, tanto para a Costa da Guiné, quanto para Lisboa. Pudemos também testar a validade do argumento sugerido pela pouca historiografia e por parte da documentação da importância dos têxteis caboverdianos para o tráfico de escravos nos Rios da Guiné, tendo em conta que Carreira apresentou dados para o comércio de tecidos na Costa, e conseguimos encontrar no Arquivo Histórico Ultramarino os custos dos escravos em África, em um Mapa Geral do Comércio da Companhia do Grão-Pará e Maranhão.

Contudo, para ter uma avaliação na longa duração da economia exportadora caboverdiana, para a montagem das séries se fizeram necessárias outras fontes. A pesquisa documental, no Arquivo Histórico do Tribunal de Contas, foi fundamental para complementar as planilhas de exportação do arquipélago. Em especial dois livros do Fundo do Erário Régio, Das Remessas de Cabo Verde, que depois de tabulados, nos ajudaram a aprofundar as informações da produção e do comércio caboverdiano. Essas informações complementaram as disponibilizadas por Carreira até o ano de 1799. Para depois disso, até 1807, utilizamos os dados das Balanças de Comércio de Portugal com seus domínios em África: assim pudemos complementar a série do principal produto de exportação das ilhas, observar as permanências e mudanças na produção insular, os incrementos produtivos, entre outras coisas.

Por fim, o trabalho pode ser complementado a partir da transcrição de boa parte da correspondência trocada entre os administradores da empresa pombalina, seus funcionários em Cabo Verde e Guiné, bem como com os capitães das embarcações imbuídas no tráfico de escravos na região. A investigação focou-se, sobretudo, no já referido Fundo da Companhia Geral do Comércio do Grão-Pará e Maranhão, disponível no Arquivo Nacional da Torre do Tombo. Tal documentação foi de grande importância, pois através dessa troca de informações entre o corpo administrativo da Companhia com seus subordinados no Ultramar, foi possível compreender as nuances de como se 
configurou e como se dava o funcionamento do negócio negreiro na região, ponto fundamental de nossa pesquisa. ${ }^{28}$

Outros fundos importantes também foram consultados. Dentre eles, o Fundo Conde de Linhares em que encontramos uma descrição bastante interessante sobre os estabelecimentos portugueses em Cacheu e Bissau, feita pelo tenente Bernardino António Álvares de Andrade, em 25 de maio de 1777, que serviu por uma década na região. ${ }^{29}$ Também tivemos acesso a três publicações antigas, as quais só encontramos no acervo da Torre do Tombo e permitiram acrescentar novos fatos em nosso trabalho: a primeira tratava da construção da fortaleza em Bissau, bem como da ação da Companhia do Grão-Pará e Maranhão; a segunda discorria sobre as negociações do Império Português com os poderes locais em Bissau; por fim, uma terceira que falava sobre os capitães-mores das praças portuguesas na Guiné. ${ }^{30}$

A partir da mobilização de todo esse corpo documental, sua tabulação nos casos quantitativos e posterior análise de tudo que foi levantado em Arquivo e Acervos - sejam eles físicos ou digitais - nos possibilitou a redação desse trabalho. Trabalho esse, dividido nesta introdução, três capítulos e mais as considerações finais. Em seguida, fazemos breve resumo do que fora tratado em cada capítulo.

\section{Dos Capítulos}

No primeiro capítulo, denominado $O$ Arquipélago de Cabo Verde como Entreposto do Tráfico de Escravos nos Rios da Guiné, buscamos mobilizar as fontes referentes ao arquipélago de Cabo Verde, buscando situá-lo na esfera da economia atlântica portuguesa. Também procuramos estabelecer algumas de suas relações administrativas, econômicas e sociais com as feitorias portuguesas nos Rios da Guiné. Dividimos o capítulo em duas partes: na primeira parte intentamos discutir como se deu a ocupação das ilhas, os fatores naturais que influenciaram sua colonização, a

\footnotetext{
${ }^{28}$ Fundo: CGGPM; Seção: Junta de Lisboa; Série: Copiadores; Unidade de Instalação: Cartas para Cacheu e Bissau; Referência: PT/TT/CGGPM/A/23/98; Cota: CGGPM, cartas para o Cacheu e Bissau, ${ }^{\circ}$ 98. Microfilme 7263.

${ }^{29}$ Fundo: Conde De Linhares, Maço 45 - Documento 6.

${ }^{30}$ SARAIVA, José Mendes da Cunha. A Fortaleza de Bissau e a Companhia do Grão-Pará e Maranhão. Publicações do Arquivo Histórico do Ministério das Finanças: Lisboa, 1947. ANTT: Série Vermelha 5047; ANDRADE, Bernardino António Álvares. Planta da Praça de Bissau e suas Adjacentes. Academia Portuguesa de História: Lisboa, 1952; DUARTE, Fausto. Os capitães-mores das praças da Guiné.
} 
organização administrativa, sua defesa, os impactos da criação da Companhia, como se consolidou como entreposto comercial lusitano no Atlântico, entre outras coisas. Na segunda parte, baseados nas informações qualitativas da primeira seção, procuramos apresentar, analisar e discutir os dados quantitativos levantados durante a pesquisa. Buscamos entender, nesse sentido, como se organizou a produção caboverdiana voltada para a exportação, pretendendo corroborar como se conectou com os mercados africanos de Bissau e Cacheu.

Levando em conta a colonização de Cabo Verde, como entreposto que garantia o mercado de escravos nos Rios da Guiné, por uma série de motivos, passamos ao segundo capítulo. Intitulado O Tráfico de Escravos nos Rios da Guiné: as Praças de Cacheu e de São José de Bissau, foi dividido em três partes: na primeira, fazemos um movimento parecido com o primeiro tópico do capítulo sobre Cabo Verde. Buscamos caracterizar as praças de Cacheu e de Bissau, explanando sobre sua organização administrativa, política e social. A partir dessas informações, na segunda parte, pudemos avaliar como esses arranjos influenciaram o tráfico de escravos na região, do ponto de vista quantitativo. Por fim, na terceira parte, com os dados referentes ao comércio negreiro e das exportações de têxteis caboverdianos para a Costa da Guiné, pudemos testar a tese sobre indispensabilidade desses panos para a compra de africanos em ambas as feitorias.

Finalmente, no terceiro capítulo, denominado A Economia Amazônica na Longa Duração (c.1680 - 1807), buscamos avaliar os impactos do tráfico de escravos, com origem nos Rios da Guiné, na Amazônia - particularmente nas capitanias do GrãoPará e Maranhão. Destarte, introduzimos o capítulo discutindo como foram os esforços de ocupação e defesa do território, bem como sua posterior colonização. Posto isso, partimos para a análise de sua economia, no âmbito da longa duração. Optamos por esse enfoque, pois somente assim poderíamos compreender os efeitos do comércio de escravos na região, pois notamos a existência de uma ruptura crucial, do ponto de vista econômico: a criação da Companhia de Comércio e o estabelecimento da rota de tráfico que ligava a Amazônia e os Rios da Guiné.

Nesse sentido, dividimos nossa análise no antes e depois da criação da empresa pombalina, para entender como ocorreu esse ponto de viragem na economia amazônica como um todo. Depois disso, partimos para uma análise delineada da produção e 
comércio das capitanias do Norte da América Portuguesa: buscamos particularizar as economias do Maranhão e do Grão-Pará separadamente, avaliando como havia se organizado a produção com a criação da Companhia, os principais gêneros produzidos, as oscilações de ambas economias, bem como os impactos sociais causados pela entrada regular de escravos africanos.

Sendo assim, pretendemos articular uma discussão, que abarcasse o funcionamento desse novo circuito comercial que envolvia metrópole, Cabo Verde, Rios da Guiné e Amazônia, no escopo da dinâmica econômica portuguesa no Atlântico. Acreditamos ter sido possível a empreitada, pois conseguimos mobilizar uma quantidade considerável de documentação, bem como a construção de séries quantitativas bastante confiáveis. Pensamos serem satisfatórias, do ponto de vista historiográfico, nossas análises e discussões acerca não só do tráfico negreiro nos Rios da Guiné, como também da importância de Cabo Verde para a existência desse comércio de escravos, e mais: como essa nova rota no Atlântico Equatorial trouxe profundas transformações na economia e sociedade amazônica.Dessa forma, pudemos compreender as especificidades de cada região estudada e como essas características específicas configuraram o modelo de negócio que era realizado. Esperamos que nosso trabalho, possa trazer novas questões e contribuições em relação ao já consolidado debate acerca do tráfico de escravos e da escravidão. 


\title{
CAPÍTULO I - O ARQUIPÉLAGO DE CABO VERDE COMO ENTREPOSTO DO TRÁFICO DE ESCRAVOS NOS RIOS DA GUINÉ
}

\author{
Havia, portanto, de um lado a exploração \\ agropecuária (dentro das proporções do meio e da \\ época) e o artesanato de panos de algodão \\ (registrado logo nos anos de 1517) e, de outro \\ lado, a atividade mercantil: permuta de \\ mercadorias trazidas da Europa (do Mediterrâneo \\ e norte da África) e do Oriente, por gêneros \\ africanos, por metais preciosos (ouro) e por \\ escravos. $^{31}$
}

Neste primeiro capítulo, será discutido como a colonização do arquipélago caboverdiano por Portugal permitiu que se estabelecesse na Costa da Guiné ao menos duas feitorias de tráfico de escravos: Bissau e Cacheu. Também como sua posição estratégica o transformou em um entreposto para o comércio negreiro, bem como evoluiu sua economia agrícola, têxtil e de coleta da urzela (uma espécie de líquen tintureiro). O capítulo está dividido em duas partes: a primeira delas, contextualiza a chegada e ocupação dos portugueses nas ilhas, destacando elementos da administração local e de como se organizou o tráfico nos Rios da Guiné a partir de Cabo Verde; uma segunda parte, analisa os dados disponíveis sobre a economia caboverdiana, sobretudo entre 1756 e 1807, em que as séries estão mais completas.

\subsection{Os portugueses e a colonização de Cabo Verde}

O Arquipélago de Cabo Verde está situado no Oceano Atlântico, acerca de 500 quilômetros da costa ocidental africana, na altura do que hoje se conhece por Senegal e defronte ao promontório africano que emprestou seu nome ao conjunto de ilhas.É um arquipélago constituído por dez ilhas: Santo Antão, São Vicente, Santa Luzia, São Nicolau, Sal, Boa Vista, Maio, Santiago, Fogo e Brava, além de alguns ilhéus e ilhotas que historicamente fazem parte do território caboverdiano; sendo a maior, a ilha de Santiago e a de menor dimensão a ilha da Brava.O arquipélago também se divide em

${ }^{31}$ CARREIRA, António. Cabo Verde: Formação e Extinção de uma Sociedade Escravocrata (14601878). Lisboa: Mem Martins, 1983. (p.39) 
duas regiões:Sotavento, que compreende as ilhas de Maio, Santiago, Fogo e Brava; e as ilhas de Barlavento, que são a de Santo Antão, São Vicente, Santa Luzia, São Nicolau, Sal e Boa Vista. ${ }^{32} \mathrm{O}$ mapa abaixo ilustra essa descrição: ${ }^{33}$

Mapa I. Arquipélago de Cabo Verde

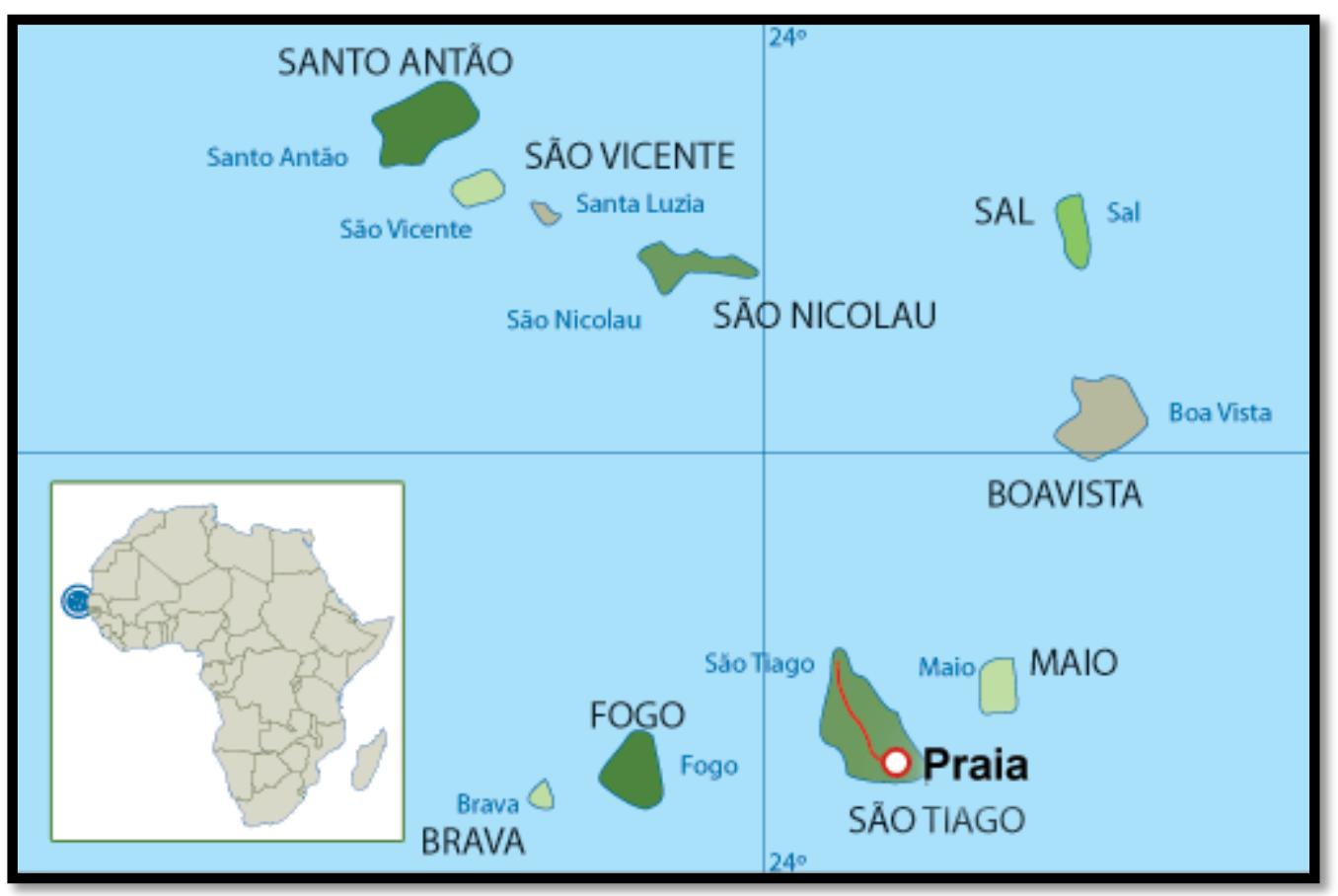

A ocupação portuguesa nas ilhas atlânticas, que margeiam a costa africana, teve início em Cabo Verde. O modelo de colonização utilizado no arquipélago foi baseado em capitanias hereditárias. A ocupação das ilhas deu-se através da importação de escravos, oriundos dos rios da Guiné, que começaram a cultivar e criar gado para subsistência. Em seguida, foi introduzida a cana de açúcar, cultivada aos moldes das ilhas da Madeira e Açores, ao mesmo tempo em que começava a se tornar um entreposto português para o comércio de escravos africanos.Já no início do povoamento do arquipélago - em meados de 1460 - D. Afonso V emitiu uma carta de privilégios aos moradores de Cabo Verde. Estes podiam livremente adentrar os rios da Guiné em busca de escravos e outros produtos. Pagando os tributos devidos a Coroa, poderiam vender os

\footnotetext{
${ }^{32} \mathrm{http} / / / w w w . g o v e r n o . c v /$. Acesso em 14/07/2014.

${ }^{33} \mathrm{http}$ ///www.searchweb101.com/cape-verde-world-map/. Acesso em 12/07/2014.
} 
escravos e outros gêneros a quem quer que fosse, além de contar com remessas oriundas das outras ilhas atlânticas livres de qualquer tributação. ${ }^{34}$

$\mathrm{Na}$ viragem do século, o percebeu-se uma espécie de diversificação da economia caboverdiana. O foco ainda era a produção agropastoril, com espaço significativo para o comércio com a costa africana, em que circulavam produtos europeus - principalmente oriundos do mediterrâneo - e também do Oriente, e que eram trocados por produtos vindos do interior da África, sobretudo metais preciosos e escravos. Mas o interessante em se observar, é que a partir de 1517, começaram a se desenvolver pequenas manufaturas artesanais de panos. Ressalta-se que o algodão e principalmente os têxteis sempre foram produtos fundamentais no tráfico de escravos. É justo pensar que o desenvolvimento da cotonicultura e de manufaturas têxteis no arquipélago desde o início de sua ocupação e colonização - conjuntamente com a estratégica posição geográfica, relativamente próxima a costa - foi fator preponderante para que o arquipélago viesse a se tornar importante entreposto comercial para o trato de almas na costa da Guiné. ${ }^{35}$

Durante os séculos XVI e XVII a Coroa tentou, de todas as formas, controlar o negócio através de contratos e arrendamentos que vedavam aos moradores do arquipélago se imbuírem no tráfico, a não ser que fossem resgatar escravos para o próprio uso e povoação das ilhas. Tal fato, juntamente com a dificuldade de fiscalização pelos agentes da Coroa, fez com que se aumentasse abruptamente o contrabando nos rios da Guiné. Capitaneado pelos moradores das ilhas de Santiago e do Fogo, tendo auxílio de comerciantes estrangeiros para ter acesso às mercadorias defesas que eram utilizadas no comércio negreiro, começaram a adentrar os rios da Guiné para o trato negreiro e de outras mercadorias africanas. Esses contrabandistas, muitas vezes, assimilavam costumes africanos e ficavam conhecidos na região como lançados ou tangomaos. Pela facilidade de acesso aos territórios hostis do sertão africano, eram sempre procurados por ingleses, franceses e holandeses para realização do tráfico. ${ }^{36}$

\footnotetext{
${ }^{34}$ CARREIRA, António. Cabo Verde: Formação e Extinção de uma Sociedade Escravocrata (14601878). ICVL: Praia, 1983. (p.27-8). SANTOS, Maria Emília Madeira (org.). História Geral de Cabo Verde. IICT: Lisboa, 1991. Vol. 1. (p. 26 e 68).

${ }^{35}$ CARREIRA.Op. Cit. (p. 30); SANTOS. Op. Cit. (p.240).

${ }^{36}$ CARREIRA. Op.cit. (p.53). Mercadorias defesas eram aqueles produtos fundamentais ao negócio de escravos na costa africana, vindos geralmente da Europa, Açores, Madeira e Canárias, as quais eram vedadas aos moradores do arquipélago de Cabo Verde possuir ou negociar. O intuito da Coroa
} 
A ação dos contrabandistas, além de lesar os contratadores, prejudicava em paralelo a arrecadação régia. É então,em 1664,que a Coroa passou pela primeira vez o controle do tráfico de escravos para companhias de comércio. Do referido ano até o ano de 1675, o trato negreiro ficou sob o monopólio da Companhia da Costa da Guiné (também conhecida como Companhia do Porto de Palmida); de (1776 a 1782?), a Companhia de Cacheu, Rios e Comércio da Guiné; de 1690 até 1703, a Companhia de Cacheu e Cabo Verde que possuía o monopólio do comércio de escravos para América Espanhola. $^{37}$

Durante a segunda metade do século XVII, depois de carta régia emitida em 1651, Cabo Verde se tornaria um entreposto fiscal da Coroa. Os navios só poderiam comerciar na Costa da Guiné com autorização emitida no Reino e deveriam pagar os donativos no arquipélago. Contudo neste período o tráfico de escravos na região não era de exclusivo para os portugueses. A Coroa abriu comércio aos navios espanhóis que ali viessem desde que o negócio fosse feito em ouro, prata e têxteis, medida semelhante da que fora tomada em Angola, mas aqui no caso a atitude da metrópole estava muito mais ligada a fragilidade da posição lusa na região. De certo, isso acabou caucionando a ação de ingleses, franceses e, sobretudo os holandeses: estes procuravam a região na intenção de trocar gêneros e mantimentos pelo ouro trazido pelos espanhóis. ${ }^{38}$

Apesar das constantes tentativas de ocupar a costa da Guiné, o domínio português continuou a ser frágil. Isso suscitou no estado de abandono das praças comerciais na Costa e do povoamento do arquipélago. Com a criação da Companhia de Cacheu e rios de Guiné em 1675, a situação piorou ainda mais para os colonos do arquipélago: isso porque se encontravam "impedidos" de fazer seus negócios, tais quais vender os gêneros produzidos nas ilhas e adquirir escravos para o seu plantel.Com a economia num quase colapso e cerceados comercialmente pela Companhia, houve no final do século XVII uma forte onda de imigração de colonos - que estavam estabelecidos nos principais núcleos urbanos caboverdianos - para a Guiné, na tentativa de escapar do controle monopolista e manter seus negócios. Isso tendeu a piorar ainda

Portuguesa, nesse sentido, fora de coibir o contrabando nos rios da Guiné, que ocorria por intermédio dos insulares caboverdianos. SANTOS. Op. Cit. (p.240). (p.241-3 e 253). Entrarei em maiores detalhes sobre os tangomaos e lançados, bem como sua atuação no tráfico de escravos nos Rios da Guiné, no Capítulo II deste trabalho.

${ }^{37}$ CARREIRA. Op. Cit. 1986. (p.67)

${ }^{38}$ Idem. (p.79). 
mais o estado da colonização em Cabo Verde, já que só aqueles colonos com menos recursos e menos possibilidades de expandir a produção ali ficaram. ${ }^{39}$

É fato que a Companhia não trouxe desenvolvimento econômico ao complexo e muito menos estabeleceu o domínio luso na região. Com o fim da concessão, o tráfico em particular, passou a ser realizado através de permissões cedidas a vassalos. Logo se mostrou ineficiente, pois isso acabava por favorecer o contrabando e o negócio com estrangeiros. Novamente, em 1690, uma nova Companhia foi proposta: a de Cacheu e Cabo Verde. Essa, por sinal, foi a primeira tentativa de unir as duas margens do Atlântico Equatorial: a Costa da Guiné e a Amazônia.

Contudo, como não contava com o exclusivo comercial - apenas para o tráfico - esta última empresa fomentista não teve grande impacto na economia da região, inexistindo uma política efetiva e coerente para consolidar a colonização portuguesa. Os corpos diretivos iam fazendo experiências na administração do complexo, na maioria das vezes muito pouco eficazes. Queriam controlar portos estratégicos para o tráfico na Guiné, bem como o comércio de outros gêneros, e afastar a concorrência estrangeira (ingleses, franceses e holandeses), mas pouco investiam na estruturação e defesa das praças de Bissau e Cacheu, como também em Cabo Verde, que poderia se tornar importante entreposto para o tráfico de escravos. ${ }^{40}$

Essa falta de investimento, na colonização e defesa do arquipélago, é algo que vai também perdurar durante o século XVIII. Somem-se ao fato as intempéries climáticas que assolavam as ilhas, e tem-se um cenário caótico em alguns períodos específicos. Em meados dos anos de 1750, Cabo Verde passava por grandes dificuldades por causa da fome e da peste. Em memória de 15 de maio de 1753, o desembargador Custódio Correia de Mattos, falava desses problemas climáticos que assolam as ilhas de tempo em tempo. Dizia também que as secas eram tão drásticas que muitas das ilhas ficavam completamente desertas e que pelo menos um sexto da população das ilhas sucumbiu a essas intempéries. Mattos, porém, fez uma pequena

\footnotetext{
${ }^{39}$ CARREIRA. Op. Cit. 1986. (p. 181); SANTOS. Op. Cit. (p.255-8).

${ }^{40}$ CARREIRA. Op. Cit. 1986. (p.211)
} 
ressalva, dizendo que apesar de tudo eram incríveis as possibilidades do quanto se podia produzir quando as condições se encontravam ideais para a agricultura e pecuária. ${ }^{41}$

O estado de abandono das fortificações, soma do às crises climáticas resultava em outro problema, recorrente durante a segunda metade do século XVIII, que era a ação dos contrabandistas estrangeiros,sobretudo os ingleses. Segundo Mattos, de início iam às ilhas onde os mantimentos eram abundantes e os compravam a preços baixos; em seguida seguiam para as ilhas assoladas pela seca e pela fome, e os vendiam a preços absurdos. Depois passavam a negociar urzela com os moradores em Cabo Verde, na tentativa de contornar o estanco real da produção. O contrato da urzela, apesar de ser uma maneira da Coroa controlar de perto a produção e evitar prejuízos, acabava muitas vezes piorando ainda mais a situação: na maioria dos casos, as embarcações acabavam não trazendo outros gêneros básicos necessários a subsistência dos moradores das ilhas. $^{42}$

Contudo, o grande problema a ser resolvido era outro: o negócio que envolvia o contrabando de têxteis e de escravos. Pedro José Cardoso de Almeida - capitão e sargento-mor da Ilha do Fogo - em requerimento ao rei, reclamava dos soldos que eram pagos em milho, panos de algodão e outros gêneros semelhantes; contudo, estes soldos em forma de gêneros só podiam ser realizados em escravos, cera e marfim vindos da Guiné.Em carta de 24 de janeiro de 1756, Luis Antônio Cunha - então Governador de Cabo Verde - reclamava do contrabando de panos feitos pelos moradores das ilhas. Os moradores mais pobres o faziam, porém não causavam muitos prejuízos, porque vendiam dois ou três panos; enquanto isso, os moradores mais abastados vendiam cerca de 200 panos. Dava conta ainda, de que da ilha de Santiago saiam cerca de oito moradores todos os anos, levando cerca de quatro mil peças à ilha de Barramento

\footnotetext{
${ }^{41}$ Arquivo Histórico Ultramarino. Avulsos de Cabo Verde, Caixa 23, documento 05; Ofício do ouvidor Francisco Xavier de Araújo, de 28 de fevereiro de 1750. Caixa 24, documento 50; Memória do desembargador Custódio Correia de Mattos, de 15 de maio de 1753.

${ }^{42}$ Urzela (RoccellaTinctoria) é uma espécie de líquen tintorial, que produz um corante azul-violáceo, utilizado nas manufaturas têxteis para o tingimento de tecidos de algodão. Seu crescimento se dá em regiões com muitas rochas costeiras, bastante comum nos arquipélagos atlânticos. Cf: SOARES, Fernandes. Dicionário Moderno Ilustrado. Cograe: São Paulo, 1959. Vol. 3. Arquivo Histórico Ultramarino. Avulsos de Cabo Verde, Caixa 24, documento 50; Memória do desembargador Custódio Correia de Mattos, de 15 de maio de 1753. Caixa 25, documento 45; Ofício do ouvidor geral Francisco Roiz Guerra, de 26 de junho de 1755.
} 
negociar com estrangeiros, sobretudo ingleses, buscando os víveres necessários e moedas. $^{43}$

Durante o século XVII e XVIII, se viu em Cabo Verde uma escassez de moedas. As poucas moedas que circulavam, não demoravam em fluir para a Costa da Guiné. Nesse sentido, os panos da terra acabaram se tornando elemento fundamental nos negócios das ilhas. Enquanto entre os moradores, os negócios se davam através de trocas de produtos, entre esses e os comerciantes vindos de fora, o pagamento se dava através de panos de algodão produzidos no arquipélago. A procura por esses panos pelos comerciantes era muito grande e trazia problemas para a administração das ilhas e até mesmo para as feitorias estabelecidas na Guiné, já que muitos desses tecidos eram contrabandeados com o intuito de comprar escravos nos rios da Guiné e em outras partes da costa do Senegâmbia.

A ação contrabandista bastante ostensiva nas possessões portuguesas no Golfo da Guiné, denota um poder imperial incipiente no arquipélago. Tendo em vista que as ilhas eram desabitadas até a chegada dos portugueses, não havia como estabelecer alianças com régulos locais com o intuito de garantir o controle das ilhas e de seus portos. Além das condições climáticas, que dizimava a população e prejudicava a ocupação e melhor utilização do território, uma falta de organização do sistema tributário diminuía a arrecadação já incipiente; e nesse sentido, as fortalezas se encontravam em ruínas, o armamento em péssimo estado de funcionamento e as tropas formadas por poucos soldados que vestiam trapos, andavam descalços e mal sabiam manusear a artilharia e armas de fogo. ${ }^{44}$

Organizar um sistema eficiente de arrecadação sempre foi um problema para os governadores de Cabo Verde. Em meados do século XVIII ainda não havia um regimento que ordenasse o recolhimento das dízimas da alfândega, da terra, bem como os direitos oriundos dos rios da Guiné. Em ofício de 30 de agosto de 1751, foi aberta uma sindicância contra o governador João Zuzarte de Santa Maria, para investigar como andava funcionamento da arrecadação. Para o desembargador Custódio Correa de

\footnotetext{
${ }^{43}$ Arquivo Histórico Ultramarino. Avulsos de Cabo Verde, Caixa 23, documento 34. Requerimento do capitão-mor da Ilha do Fogo Pedro José Cardoso de Almeida, de 15 de outubro de 1750.

${ }^{44}$ Arquivo Histórico Ultramarino. Avulsos de Cabo Verde, Caixa 26, documento 06. Carta do governador Luis Antônio Cunha, de 24 de janeiro de 1756.
} 
Matos - que conduzia a sindicância - era nítida a má administração no que tange o sistema de tributação e que era necessário que se

melhorem [os interesses] os da Fazenda Real e que se emendem os abusos e furtos intoleráveis até aqui praticados nas ilhas de Cabo Verde, sem contraditor todos eles param ou nos que imediatamente se fazem a mesma Real Fazenda, não se arrecadando nem administrando como convém. ${ }^{45}$

Pode-se dizer que a grande tentativa portuguesa para estabelecer-se na região, foi no período pombalino. Durante a primeira metade do século XVIII, o que se viu na Guiné e ilhas não foi muito diferente do que fora nos séculos anteriores. A criação da Companhia do Grão-Pará e Maranhão, em 1755, foi a experiência mais duradoura dentre as empresas monopolistas lusitanas. Pombal retomou a experiência da Companhia de Cacheu e Cabo Verde, e novamente tentou unir as margens equatoriais do Atlântico. Dessa vez, conseguiu ser um pouco mais efetivo, pelo menos no que diz respeito às relações comerciais entre o complexo Cabo Verde e rios da Guiné e a Amazônia.

Apesar de criada em 1755 é somente em 20 de janeiro de 1758 que iria aparecer a primeira correspondência sobre a Companhia do Grão-Pará e Maranhão; nela o governador de Cabo Verde no período - Manoel Antônio de Sousa - dava conta da chegada de uma galera do "contrato do Maranhão". Sousa ainda comentava que junto a essa embarcação veio carta especificando as ditas obrigações do exclusivo, mandandoo, juntamente com o seu corpo administrativo, dar todo o subsídio necessário aos administradores da Companhia que ficariam assentados na ilha de Santiago - a principal ilha do arquipélago, onde ficava sediado o corpo diretivo do complexo. Fazia-se necessário proibir todo o comércio com navios nacionais ou estrangeiros que não fossem da empresa. O governador ressaltava ainda que a empresa iria ser de fundamental importância para o incremento da economia do arquipélago, mas que era necessário mandar com urgência pessoal capacitado para gerir o trabalho. ${ }^{46}$

\footnotetext{
${ }^{45}$ Arquivo Histórico Ultramarino. Avulsos de Cabo Verde, Caixa 23, documento 63. Ofício do desembargador Custódio Correa de Matos, de 30 de agosto de 1751.

${ }^{46}$ Arquivo Histórico Ultramarino. Avulsos de Cabo Verde, Caixa 26, documento 56. Carta de Manoel Antônio de Sousa, de 20 de janeiro de 1758. Caixa 26, documento 77, Carta do mesmo autor, de 26 de junho de 1759 .
} 
Em carta ao rei de 1761, o ouvidor geral de Cabo Verde, Carlos José de Sotto Mayor dizia que o comércio nas ilhas estava florescente para os interesses da Companhia do Grão-Pará e Maranhão. Contudo, fez algumas ponderações: o comércio de exclusivos da empresa trazia problemas aos moradores, já que por conta do monopólio havia diminuído os preços de alguns produtos que vendiam a Companhia, e que em boa parte das negociações a tinham seus produtos trocados por outros gêneros. Alertava que nesse sentido, com as trocas prejudicando os habitantes, muito provavelmente declinaria as fábricas de tecidos, a cotonicultura e a colheita da urzela que eram as forças motrizes da produção e da economia do arquipélago. ${ }^{47}$

O exclusivo do tráfico de escravos, também punha em risco as lavouras de algodão e as manufaturas de têxteis. Apesar de haver muitos habitantes que poderiam ser utilizados na lavoura, esses se recusavam ao trabalho braçal. Nisso, apenas àqueles proprietários com mais posses - que eram uma parcela pouco significativa da população caboverdiana - poderiam comprar escravos. Contudo, com o número pequeno destes, o resultado poderia ser um possível colapso da produção algodoeira e têxtil do arquipélago. Sugeria também que a Companhia pagasse os filhos da folha com alguns escravos e que estes fossem vendidos aos habitantes a dinheiro ou a gêneros da terra. Ou até mesmo vender fiado a alguns pequenos lavradores, que ficariam obrigados a utilizar os escravos na cotonicultura e manter assim os níveis produtivos. ${ }^{48}$

Apesar dos problemas apontados pelo ouvidor, durante a década de 1760, aparentemente havia instalado um estado de paz e prosperidade nas ilhas com a atuação da empresa monopolista. Os esforços estavam voltados para o conserto e melhoria da artilharia, na limpeza urbana e no reparo das fortalezas. Apesar disso, os próprios números do comércio praticado pela Companhia mostram um comércio oscilante, que vai se perpetuar por toda a segunda metade do Setecentos. Tal oscilação mercado pode ser corroborado, pelos números observados na tabela abaixo ${ }^{49}$ :

\footnotetext{
${ }^{47}$ Arquivo Histórico Ultramarino. Avulsos de Cabo Verde, Caixa 27, documento18. Carta do ouvidor geral Carlos José de Sotto Mayor, de 15 de maio de 1761.

${ }^{48}$ Idem.

${ }^{49}$ Arquivo Histórico Ultramarino. Avulsos de Cabo Verde, Caixa 28, documento 37. Memória de autor anônimo, de 17 de junho de 1764.
} 
Tabela I - Mapa do Comércio da Companhia do Grão-Pará e Maranhão (em réis)

\begin{tabular}{|c|c|c|c|c|}
\hline ANOS & FAZENDAS & DINHEIRO & LETRAS & TOTAL \\
\hline 1757 & $9: 618 \$ 108$ & 0 & 0 & $9: 618 \$ 108$ \\
\hline 1758 & $3: 325 \$ 180$ & 0 & 0 & $3: 325 \$ 180$ \\
\hline 1759 & $32: 097 \$ 225$ & 0 & $400 \$ 000$ & $32: 497 \$ 225$ \\
\hline 1760 & $11: 981 \$ 629$ & 0 & 0 & $11: 981 \$ 629$ \\
\hline 1761 & $36: 949 \$ 246$ & 0 & 0 & $36: 949 \$ 246$ \\
\hline 1762 & $7: 389 \$ 482$ & $1: 200 \$ 000$ & $1: 195 \$ 000$ & $9: 784 \$ 482$ \\
\hline 1763 & $3: 971 \$ 041$ & 0 & $1: 252 \$ 200$ & $5: 223 \$ 241$ \\
\hline 1764 & $16: 831 \$ 180$ & 5:000\$000 & 0 & $21: 831 \$ 180$ \\
\hline 1765 & $22: 362 \$ 279$ & $8: 000 \$ 000$ & $610 \$ 000$ & $30: 972 \$ 279$ \\
\hline 1766 & $12: 525 \$ 286$ & 0 & $2: 551 \$ 728$ & $15: 077 \$ 014$ \\
\hline 1767 & $17: 787 \$ 744$ & 0 & $1: 750 \$ 533$ & $19: 538 \$ 277$ \\
\hline 1768 & $36: 003 \$ 796$ & 0 & $4: 830 \$ 765$ & $40: 834 \$ 561$ \\
\hline 1769 & $17: 784 \$ 611$ & $2: 400 \$ 000$ & $4: 703 \$ 819$ & $24: 888 \$ 430$ \\
\hline 1770 & $27: 909 \$ 054$ & 0 & $3: 026 \$ 045$ & $30: 935 \$ 099$ \\
\hline 1771 & $13: 199 \$ 654$ & $2: 400 \$ 000$ & $3: 344 \$ 540$ & $18: 944 \$ 194$ \\
\hline 1772 & $7: 535 \$ 889$ & 0 & $5: 701 \$ 890$ & $13: 237 \$ 779$ \\
\hline 1773 & $7: 400 \$ 625$ & 0 & $8: 696 \$ 287$ & 16:096\$912 \\
\hline 1774 & $25: 328 \$ 900$ & 0 & $8: 986 \$ 202$ & $34: 315 \$ 102$ \\
\hline 1775 & $7: 437 \$ 942$ & 0 & $7: 553 \$ 912$ & $14: 991 \$ 854$ \\
\hline 1776 & $878 \$ 569$ & 0 & $4: 595 \$ 067$ & $5: 473 \$ 636$ \\
\hline 1777 & $5: 7514 \$ 773$ & $1: 200 \$ 000$ & $1: 438 \$ 450$ & $8: 390 \$ 223$ \\
\hline TT & 324:069\$213 & $20: 200 \$ 000$ & $60: 636 \$ 438$ & $404: 905 \$ 651$ \\
\hline
\end{tabular}

Fonte: Arquivo Histórico Ultramarino. Avulsos de Cabo Verde, Caixa 37, documento 48-B. Mapa Geral do Comércio da Companhia de Comércio do Grão-Pará e Maranhão, de 19 de dezembro de 1778

A oscilação é clara e evidente nos números. Só a título de exemplo, entre os anos de 1758 e 1760, se assistiu um crescimento de dez vezes entre 1758 e 1759, e uma queda para menos da metade dos negócios entre 1759 e 1760. E isso é algo corriqueiro no decorrer do período de funcionamento da Companhia. Isso se dá - muito 
provavelmente - devido às intempéries climáticas já referidas. Os períodos de seca vão influenciar diretamente na produtividade, pois nos casos mais extremos não se produzia nem o necessário para a subsistência. A empresa monopolista pode não ter conseguido o objetivo de ampliar a produção do arquipélago, mas teve sua importância para as ilhas.

Durante o período do monopólio exercido pela Companhia do Grão-Pará e Maranhão, os administradores da empresa participavam ativamente da vida política do arquipélago, bem como das decisões a serem tomadas na governação não só das ilhas, como nos rios da Guiné. Para que os projetos fossem levados adiante, normalmente, deveriam estar de comum acordo o ouvidor-geral, o governador e os administradores nas decisões tomadas. Sentindo a fragilidade dos poderes imperiais estabelecidos no complexo, os administradores da empresa pombalina começaram a atuar como provedores, fiscalizando as alfândegas e feitorias. Percebe-se, nesse sentido, uma fusão entre os poderes público e privado, já que os administradores estavam a serviço de uma sociedade de comerciantes estabelecidos sobretudo no Reino, mas atuavam - ao mesmo tempo - em funções que deveriam ser exercidas por funcionários régios ${ }^{50}$, algo comum no Antigo Regime.

Apesar desse aparente período de prosperidade econômica, a Companhia era sempre foco de reclamação dos habitantes do arquipélago. Em 26 de junho de 1771, o governador Joaquim Salema de Saldanha Lobo, dava conta da falta de algodão para a produção de têxteis. Grande parte dos moradores não possuía condições para comprar escravos para as suas lavouras. Além disso, vedada a possibilidade de fazer qualquer tipo comércio, esses insulares não tinham acesso ao mercado sem ser por intermédio da empresa fomentista: a Companhia vendia seus produtos pelo dobro do que valiam, e comprava a produção dos moradores a preços muito baixos, normalmente pagando com gêneros. ${ }^{51}$

Em novembro de 1772, por exemplo, houve um período de seca e fome na ilha de Santo Antão, uma das mais importantes do arquipélago. Os habitantes, num momento de fome extrema chegaram a comer uma manada de jumentos, inclusive

\footnotetext{
${ }^{50}$ Arquivo Histórico Ultramarino. Avulsos de Cabo Verde, Caixa 27, documento 20. Carta do ouvidor geral Carlos José de Sotto Mayor, de 14 de abril de 1761. Caixa 30, documento 53. Carta da secretaria de Estado e Ultramar, de 21 de agosto de 1765.

${ }^{51}$ Arquivo Histórico Ultramarino. Avulsos de Cabo Verde, Caixa 32, documento 14. Carta do governador Saldanha Lobo, de 26 de junho de 1771.
} 
chegando a torrar os ossos para comê-los. Morreram mais de mil e quinhentas pessoas, reflexo da fome e da epidemia que houve logo em seguida. Faltavam mantimentos, segundo o governador Saldanha Lobo, que acusava a Companhia de não se preocupar em enviar mantimentos, e quando fazia cobrava preços abusivos. Além disso, na política de distribuição de terras, estas eram arrendadas e quando se terminava o ciclo do plantio, os arrendatários tinham suas terras tiradas pelos administradores da empresa, que a destinava a outra pessoa de acordo com seus interesses particulares. ${ }^{52}$

A Companhia nunca deixou de ser alvo de muita reclamação por parte dos moradores e governadores de Cabo Verde. Em carta de maio de 1773, o Governador Saldanha Lobo dizia que a empresa monopolista detinha a cobrança dos dízimos das ilhas, e que isso causava uma série de problemas no que diz respeito ao pagamento dos filhos da folha. Reclamava também dos sucessivos aumentos dos preços, praticados pela Companhia, que costumava cobrar dois preços diferentes: um quando negociava em troca de panos, e outro quando negociava por dinheiro.

Além disso, os administradores não cumpriam com a obrigação de reparar os danos das fortalezas, e também com a construção de uma fortificação na ilha de São Nicolau. Isso acarretava em sucessivas investidas de estrangeiros, que contrabandeavam todo tipo de produtos, além de roubarem escravos e até mesmo homens livres. O que se pode observar então é que mesmo com todas as proibições e com o comércio sob a administração da empresa pombalina, os estrangeiros continuavam a ir aos portos caboverdianos. Alguns - principalmente ingleses - iam com intuito de contrabandear pano e outros gêneros, enquanto outros - os holandeses, sobretudo - iam com intuito de comprar víveres básicos para viajar para as Índias Orientais. ${ }^{53}$

Na segunda metade da década de 1770, são inúmeras as correspondências trocadas pelas autoridades imperiais com o Reino, em que se alertava sobre o estado de ruína em que se acham as ilhas. A culpa sempre fora dirigida a administração da Companhia, sempre com o argumento de que a empresa pagava preços baixíssimos pelos gêneros produzidos no arquipélago, ao mesmo tempo em que cobravam preços

\footnotetext{
${ }^{52}$ Arquivo Histórico Ultramarino. Avulsos de Cabo Verde, Caixa 33, documento 02. Carta do governador Saldanha Lobo, de 20 de março de 1773.

${ }^{53}$ Arquivo Histórico Ultramarino. Avulsos de Cabo Verde, Caixa 33, documento 1, 12, 15 e 17A. Várias cartas do governador Saldanha Lobo, de 22 de maio de 1773. Caixa 34, documento 04. Carta do mesmo governador, de 22 de fevereiro de 1775.
} 
acima do comumente praticado, no que diz respeito aos escravos e produtos vindos da Europa. Em uma memória de 1776, produzida pelo mesmo Saldanha Lobo, argumentava-se que o comércio estava encerrado devido ao monopólio ainda exercido da Companhia; a única atividade econômica que sobrevivia, eram as manufaturas de panos de algodão, pois estes eram fundamentais para a compra de escravos nos rios da Guiné. Contudo, faltavam escravos e a cotonicultura se via em franca decadência, o que poderia causar sérias consequiências no tráfico realizado nos rios da Guiné, bem como para a presença portuguesa na região. ${ }^{54}$

Em julho de 1777, o então governador, Antônio do Valle de Souza Menezes escrevia ao ministro de Estado, dizendo que a última seca deixara as ilhas em estado lastimável, e que novamente morrera uma grande quantidade de pessoas. Faltavam escravos e por isso pouco se conseguia produzir nas lavouras que estariam em completo abandono. E novamente o discurso oficial se repetia: a cotonicultura e a fabricação de têxteis seriam a única forma de subsistência dos moradores do arquipélago. E mais uma vez a Companhia apareceria como vilã, se aproveitando dessa situação de escassez de mão de obra e víveres para praticar preços abusivos. Diz Souza Menezes:

A administração e a mesma Companhia, ainda que bem cientes dessa necessidade, não ocorrem a ela; porque é nestes miseráveis termos, querem extrair destes habitantes o nada do que se nutrem, e pretendem vender-lhes escravos por $80 \$ 000$, em panos que transportam a Guiné, onde apuram o dobro de $160 \$ 000 .^{55}$

E continua:

E quando algum morador, por sua necessidade, lhe vende um escravo, só lhe dão 50\$000 e um tanto e em fazenda, e desta de diferença murmura o povo. ${ }^{56}$

\footnotetext{
${ }^{54}$ Arquivo Histórico Ultramarino. Avulsos de Cabo Verde, Caixa 35, documento 01. Carta do governador Saldanha Lobo, de 12 de fevereiro de 1776. Caixa 35, documento 05. Memória do mesmo governador, de 20 de março de 1776.

${ }^{55}$ Arquivo Histórico Ultramarino. Avulsos de Cabo Verde, Caixa 36, documento 13. Ofício do governador Souza Meneses, de 30 de julho de 1777.

${ }^{56}$ Idem.
} 
E por fim, solicita a

Vossa Majestade, por sua Real Clemência, permitir que os particulares possam trazer a essas ilhas escravos para o comércio de panos de algodão, ou que a Companhia os mande vir pelo preço que sempre tiveram de $60 \$ 000$, e que os moradores possam os mandar vir da Guiné, por seus panos e víveres, sem embaraço daquela administração. ${ }^{57}$

Outro problema enfrentado pelos Governadores do arquipélago era a própria dispersão das ilhas e a falta de uma comunicação eficaz entre elas. Isso resultava na insubordinação de muitos capitães-mores, das outras ilhas marginais a de Santiago. Estesatuavam de acordo com seus interesses, nomeando funcionários e delegando patentes que os favorecesse política e economicamente. Ressalte-se aqui, que a Ilha de Santiago era a principal ilha do arquipélago e a cidade de Ribeira Grande seria a capital do complexo Cabo Verde e dos rios da Guiné; era onde ficavam estabelecidos os poderes administrativos centrais e também os administradores da Companhia. Além disso, o principal porto seria o da Vila da Praia, povoação próxima a Ribeira Grande, de onde a grande maioria das embarcações atracava antes de seguir viagem para a Costa da Guiné ou para a América. ${ }^{58}$

Alguns desses capitães-mores, das ilhas com menor relevância e mais afastadas da de Santiago, ultrapassavam os limites de poder que lhe cabiam, e transformavam algumas ilhas em seus 'feudos' particulares. Um exemplo disso é um processo de meados de 1777,em que é acusado o senhorio da Ilha de Santo Antão - José da Costa Ribeiro - por apresar pretos livres para serem seus escravos. Falecido Ribeiro, a administração da ilha passou as mãos da Companhia, que também acabara acusada de escravizar esses mesmos homens e mulheres livres. Contudo, a administração se defendeu, dizendo que tratava esses pretos como servos da Coroa e os empregavam no fabrico das vinhas, do algodão e do anil e mais produções que eram de interesse da Real

\footnotetext{
57 Arquivo Histórico Ultramarino. Avulsos de Cabo Verde, Caixa 36, documento 13. Ofício do governador Souza Meneses, de 30 de julho de 1777.

${ }^{58}$ Arquivo Histórico Ultramarino. Avulsos de Cabo Verde, Caixa 31, documento 30. Ofício do governador de Saldanha Lobo, de 25 de fevereiro de 1770.
} 
Fazenda. Contudo, lavrou-se decreto de 01 de janeiro de 1780, concedendo liberdade a esses escravos. $^{59}$

Eis que com o fim do reinado de D. José I, em 24 de fevereiro de 1777, Pombal perdeu sua força política na Corte. As medidas político-econômicas postas em práticas pelo então Ministro de Estado, foram pouco a pouco sendo diluídas. Em 1778, extinguiu-se o monopólio comercial da Companhia do Grão-Pará e Maranhão. O que parecia um alento aos moradores, na verdade se mostrou um enorme problema: com o fim do exclusivo, a empresa começou a liquidar as dívidas contraídas pelos moradores, pela compra de mantimentos e outros gêneros. Na grande maioria dos casos os moradores passavam por vexações e violências. Os preços dos panos que já eram absurdamente baixos, decresceram ainda mais. Muito moradores urbanos abandonavam suas casas e iam se esconder no interior das ilhas, em uma tentativa de fugir às opressões e humilhações impostas pelos administradores. ${ }^{60}$

Além disso, o sargento-mor da Ilha do Fogo, Marcelino José Souza, comentava que, com o fim do exclusivo comercial da Companhia, ficou desbaratado o já frágil sistema tributário. Desse modo, não havia rendimentos dos dízimos e nem dos direitos sendo cobrados na Real Fazenda. Não só os tributos, mas os pagamentos de soldos, filhos da folha e côngruas também estavam sem um responsável e não poderiam ser realizados pela falta de arrecadação.O monopólio da empresa era ruim aos moradores, mas garantia que os direitos pagos nas alfândegas da Guiné se destinassem aos pagamentos dos soldos e côngruas. Com o fim do monopólio, os navios vindos dos rios da Guiné, deixavam de passar pelo arquipélago para pagar os devidos direitos. ${ }^{61}$

A ação imediata por parte da Corte foi uma ordem de D. Maria I, endossada por Martinho de Melo e Castro, ao Conselho Ultramarino para que se reorganizasse o sistema de arrecadação nas ilhas de Cabo Verde e suas anexas. Nela,

\footnotetext{
${ }^{59}$ Arquivo Histórico Ultramarino. Avulsos de Cabo Verde, Caixa 36, documento 08. Carta do governador Souza Meneses, de 16 de julho de 1777.

${ }^{60}$ Arquivo Histórico Ultramarino. Avulsos de Cabo Verde, Caixa 37, documento 09. Ofício do governador Souza Meneses, de 24 de abril de 1778.

${ }^{61}$ Arquivo Histórico Ultramarino. Avulsos de Cabo Verde, Caixa 37, documento 28. Carta do sargentomor da Ilha do Fogo, Marcelino José Souza, de 31 de julho de 1778. Caixa 38, documento 27 e 29. Ofícios do governador Sousa Meneses, de 29 de junho de 1779.
} 
[...] ordena a mesma Senhora que o Conselho Ultramarino passe as ordens necessárias para que não só o contrato da erva urzela se ponha a lanços, a fim de se arrematar na forma precedentemente praticada, mas também para porem em arrecadação os direitos da alfândega, dízimos, da chancelaria, do sal e dos foros pertencentes a Real Fazenda em todas as ditas ilhas e praças de Bissau e Cacheu, com os seus territórios; criando-se para esse efeito os oficiais que forem precisos; e dando-se todas as mais providências que parecerem justas e necessárias, assim para se fazer a cobrança de tudo, como para se pagarem as folhas eclesiástica, militar e civil das referidas ilhas e costa de África, que agora foram administradas pela mencionada Companhia. $^{62}$

Não é necessário dizer que mesmo assim, não foi possível a retomada dos antigos sistemas de arrecadação. E a saída encontrada pela Coroa foi, de fato, intrigante: em 18 de janeiro de 1780,Vossa Majestade foi "servida aprovar, e proteger uma associação de comerciantes a quem concede o privilégio exclusivo das ilhas de Cabo Verde e da costa da África, desde o Cabo Branco até o Cabo das Palmas, assim e da mesma forma, com que o teve a Companhia do Grão-Pará e Maranhão". ${ }^{63}$ A esta sociedade de comércio também seria encarregada e responsável pela manutenção das praças comerciais, pelo pagamento dos filhos da folha e a cobrança de todos os dízimos reais: ${ }^{64}$

E porque fica a cargo da Fazenda Real a conservação de todas as praças que o estiveram da Companhia do Pará, as suas despesas, os pagamentos dos soldados, os ordenados de todos os militares, ministros, oficiais de justiça, fazenda e a folha eclesiástica, que tudo excede em grande parte aos rendimentos dos direitos reais das ditas ilhas. Esta sociedade querendo indenizar Sua Majestade deste prejuízo, de forma que não venha a ser gravoso ao Erário Régio, lhe oferecem em retribuição destes privilégios, e com destino para as despesas das mesmas ilhas, e costa da África vinte e seis contos de réis cada ano, entregues no Real Erário aos quartéis vencidos e

\footnotetext{
${ }^{62}$ Arquivo do Tribunal de Contas, Livro 4207 da Contadoria Geral da África Ocidental, do Maranhão e das Comarcas do Território da Relação da Bahia. Fls 13.

${ }^{63}$ Idem. Fls. 16 a 20.

${ }^{64}$ Arquivo Histórico Ultramarino. Avulsos de Cabo Verde, Caixa 43, documentos 13, 15, 20. Cartas do governador Faria e Maia, de 15 de abril de 1786.
} 
contados um ano depois de principiada essa negociação, de forma que o primeiro pagamento se fará findo o mês de setembro de 1781, e os mais sucessivamente. ${ }^{65}$

Interessante é notar que não foi possível encontrar nenhuma menção desta sociedade comercial na bibliografia. Com efeito, a criação de uma nova sociedade, que detinha o monopólio comercial, vai de encontro com certa historiografia que aponta para o reinado de D. Maria I como uma ruptura com a política pombalina. Contudo a limitação das fontes e da bibliografia não permite uma discussão mais aprofundada dessa Sociedade de Exclusivo neste trabalho. A documentação encontrada e analisada não permite compreender como se deu o funcionamento de tal empresa, como essa se sobrepôs aos moradores do complexo, bem como seus resultados econômicos. Contudo, é interessante observar essa continuidade da política proposta por Pombal no reinado de D. Maria I, logicamente que em um contexto periférico e como de fato, nunca se conseguiu desenvolver uma colonização eficiente em Cabo Verde.

Por exemplo, em carta de 06 de julho de 1786, o naturalista enviado do Reino ao arquipélago chamado João da Silva Feijó, apontava que a produção caboverdiana era precária, pois os lavradores não possuíam grandes habilidades para uma produção de larga escala, como na América. Mesmo a produção de milho, que Feijó e o então governador António Machado de Faria e Maia consideravam a cultura mais útil, era mal aproveitada. O algodão não produzia o necessário para confeccionar os panos que serviam ao tráfico. Além disso, existiam muito poucos escravos que realmente ficavam em Cabo Verde, pois como o negócio no arquipélago se dava, quase que exclusivamente, pelos gêneros da terra, acabava por não animar aos traficantes os venderem nas ilhas. ${ }^{66}$

Seja durante o funcionamento da Companhia do Grão-Pará e Maranhão, seja com a Sociedade de Exclusivo, seja após o seu fim em 1788. Cabo Verde, o vértice do complexo com os rios de Guiné, ia subsistindo de maneira improvisada,com parcos investimentos por parte da metrópole, com fortalezas destruídas e tropas insuficientes. Mesmo com a notável variedade da produção agropastoril, Cabo Verde só possuía dois produtos que interessavam a metrópole: a urzela, que não precisava de grandes recursos

\footnotetext{
${ }^{65}$ Arquivo do Tribunal de Contas, Livro 4207, fls. 16 a 20

${ }^{66}$ Arquivo Histórico Ultramarino. Avulsos de Cabo Verde, Caixa 43, documento 35. Carta do governador Faria e Maia de 06 de junho de 1786.
} 
para a sua colheita; e os panos de algodão fundamentais ao negócio de escravos na Costa, produzidos por uma protoindústria domiciliar, que funcionava com alguns míseros escravos tocando os teares.

É somente no fim do século, com a nomeação de Marcelino António Bastos como Governador do arquipélago, que a situação das ilhas parece melhorar. Em carta de 15 de maio de 1797, Bastos comenta sobre as medidas que tomou para o desenvolvimento da agricultura e da criação de gado no arquipélago. Obtém êxito com o desenvolvimento da cotonicultura na ilha da Boa Vista, e também em relação ao café, cultivado na ilha de São Nicolau. Também estava sendo produzido açúcar de ótima qualidade, mas que pretendia não desenvolver essa produção, com o intuito de não atrapalhar as culturas essenciais à Cabo Verde, principalmente em relação a criação de gado, que vinha a ser bem próspera. E por fim, o milho que é produzido abundantemente nas ilhas de Barlavento, e que sempre fora visto como produto fundamental da produção caboverdiana por boa parte dos governadores. ${ }^{67}$

Bastos se esforça também para ampliar a busca pelas tinturas naturais - anil e sangue de drago especificamente - que apesar de não possuírem uma produção muito grande para competir no mercado europeu, era fundamental na produção de panos "que fazem a principal base do comércio com a costa da Guiné." ${ }^{68}$ Buscava também a colonização das ilhas, até então desertas, como a ilha de São Vicente, para ampliar as áreas para a cotonicultura, ressaltando que

o algodão de que mostra abundantíssimo, lisonjeia [...] os novos colonos, que estando habituados a sua cultura, de que faziam o principal tráfico na ilha do Fogo, se esperançam encontrar nessa [São Vicente] melhor terreno, e as vantagens que com este ramo tem a capital no comércio da costa da Guiné. ${ }^{69}$

Os panos caboverdianos aparecem ao longo da documentação, como fundamentais ao negócio de escravos na Costa da Guiné. Nas instruções aos capitães de

\footnotetext{
${ }^{67}$ Arquivo Histórico Ultramarino. Avulsos de Cabo Verde, Caixa 50, documento 21. Carta do governador Marcelino António Bastos, de 15 de maio de 1797.

${ }^{68}$ Arquivo Histórico Ultramarino. Avulsos de Cabo Verde, Caixa 50, documento 31. Ofício do mesmo governador, de 30 de maio de 1797.

${ }^{69}$ Arquivo Histórico Ultramarino. Avulsos de Cabo Verde, Caixa 50, documento 36.Ofício do mesmo governador, de 28 de julho de 1797.
} 
navios da Companhia do Grão-Pará e Maranhão que iam traficar na Guiné, por exemplo, em todas elas - sem exceção - fazem menção da utilização desses tecidos para o tráfico. ${ }^{70}$ Contudo, é apenas com Marcelino António Bastos,que se vê maior zelo com a produção de algodão, e consequentemente com a manufatura dos têxteis. Em ofício de 16 de fevereiro de 1798, Bastos conta que estava realizando as melhorias no cultivo do algodão e de outras culturas, seguindo ordens de algumas instruções vindas do Reino. A primeira delas foi a inserção de bois e do arado para a terra. Aliado as ótimas propriedades do solo, produzia-se algodão abundantemente, mesmo nas regiões onde o cultivo era ainda bastante rudimentar. A ilha da Boa Vista se destacava como a principal produtora de algodão do arquipélago, e em carta de 17 de fevereiro de 1798, Bastos comunicava o envio para a mesma, de uma máquina descaroçadeira, que havia sido enviada para Santiago pelo Real Erário. Isso também vem demonstrar, o despertar do interesse da metrópole em desenvolver a manufatura no arquipélago. ${ }^{71}$

Também houve muitos estímulos para a descoberta de novos gêneros que poderiam ser mais bem explorados para o comércio, como salitre, pescados e drogas em geral; existia também o envio regular ao Reino de espécies novas de vegetais e animais.Além disso, o sucesso da colonização de São Vicente, fez com que expandisse a experiência de ocupar outras ilhas desertas do arquipélago, como por exemplo, a ilha de Santa Luzia. Contudo, é importante pensar que Cabo Verde nunca deixou de ser marginal no contexto das ilhas atlânticas. Jamais alcançou uma proeminência econômica, ou mesmo foi ponta de lança para novas produções, como aconteceu com o açúcar na Madeira e nos Açores. Ao fim e ao cabo, o arquipélago sempre servira de entreposto comercial para o tráfico de escravos nos rios de Guiné, e a manufatura de têxteis, mesmo não tendo produção em escala industrial, era o suficiente para garantir os mercados de Bissau e Cacheu.

Assim sendo, no item a seguir procuraremos apontar, através dos dados quantitativos, a estrutura da economia caboverdiana, tentando demonstrar os principais

\footnotetext{
${ }^{70}$ Arquivo Nacional Torre do Tombo. Fundo: CGGPM; Seção: Junta de Lisboa; Série: Copiadores; Unidade de Instalação: Cartas para Cacheu e Bissau; Referência: PT/TT/CGGPM/A/23/98; Cota: CGGPM, cartas para o Cacheu e Bissau, nº 98. Microfilme 7263.

${ }^{71}$ Arquivo Histórico Ultramarino. Avulsos de Cabo Verde, Caixa 51, documento13. Ofício do governador Marcelino António Bastos, de 16 de fevereiro de 1798. Caixa 51, documento 17. Carta do mesmo governador de 17 de fevereiro de 1798.
} 
produtos explorados, como eram produzidos e sua relevância para a manutenção da oferta de escravos nas feitorias dos Rios da Guiné.

\subsection{A Economia de Cabo Verde (1756-1807)}

Como se viu, apesar da criação da Companhia do Grão-Pará e Maranhão ter causado algum impacto na economia caboverdiana, está nunca deixou de ser titubeante. Além de Portugal nunca ter demonstrado muito entusiasmo, e até mesmo zelo, em estimular a prosperidade do arquipélago, também temos os fatores climáticos que impediam o crescimento econômico: as secas periódicas prejudicavam qualquer surto produtivo.

De 1755 a 1807, houve, pelo menos, cinco períodos de seca e crise de alimentos registrados pela documentação em Cabo Verde: entre 1754 e 1755, com falta de chuvas em todas as ilhas nos dois anos; nos anos de 1764 e 1765, em que foi declarada fome generalizada nas ilhas de Santiago, Boa Vista e São Nicolau, em que os habitantes chegaram ao ponto de comer as peles de animais já secas; entre 1773 e 1775, considerada como das piores crises vistas no arquipélago, que atingiu todas as ilhas, e com uma mortalidade na casa das vinte e duas mil pessoas; nos anos de 1790 e 1791, outra grande seca nas ilhas de Barlavento e na ilha Brava matou cerca de oitocentas pessoas; por fim, entre 1804 e 1807 uma crise de menor escala que atingiu apenas em Santo Antão, em que os habitantes se alimentavam quase que exclusivamente de troncos de bananeiras. ${ }^{72}$

Contudo, apesar das condições climáticas desfavoráveis e uma economia vacilante, é interessante observar que no período em que valia o monopólio da Companhia - para o qual temos o registro mais completo da economia de exportação caboverdiana - houve remessas variadas de gêneros produzidos e coletados nas ilhas, apesar de não serem periódicas. E o mais interessante a observar é que dali partia remessas para Lisboa e para os Rios da Guiné. A metrópole recebia uma variedade razoável de mercadorias oriundas do arquipélago, com destaque para a Urzela - o principal produto das exportações - e também para as remessas regulares de milho a

\footnotetext{
${ }^{72}$ CARREIRA. Op. Cit. 1986. (p.208-9).
} 
partir de 1798. Já as feitorias de Bissau e Cacheu recebiam de Cabo Verde, os já referidos têxteis que eram extremamente necessários para efetuar o tráfico na Costa.

A série quantitativa obtida não está completa. Os dados para os anos compreendidos entre 1779 e 1789 não foram encontrados, seja na pouca bibliografia sobre o arquipélago, seja nos arquivos portugueses. O período abarcado pelo exclusivo da Companhia e entre 1796 e 1807, são os que possuem as séries mais completas: os números do período de atuação da empresa monopolista estão todos publicados; e entre 1796 e 1807 existem os números disponibilizados nas Balanças de Comércio. Para os anos entre 1790 e 1796 existem dados para vários gêneros, principalmente a urzela, que se encontravam nos quatro volumes dos Borradores do Diário de Cabo Verde, depositado no Arquivo do Tribunal de Contas, em Lisboa ${ }^{73}$.

O fato, de certa forma, prejudica uma avaliação mais precisa do funcionamento da produção e do comércio caboverdiano na longa duração. No entanto, os dados podem contribuir para entender um pouco a dinâmica econômica das ilhas, e ter uma idéia geral do que era produzido e/ou coletado, e principalmente avaliar a importância da Urzela nas remessas para Lisboa na segunda metade do século XVIII e do milho na virada para o XIX. Outro ponto que pode ser mais bem analisado é a relevância dos tecidos manufaturados nas ilhas para o tráfico de escravos em Bissau e Cacheu, tidos por fundamentais na realização do negócio nas feitorias da Costa.

Destarte, trataremos dos produtos menos relevantes no âmbito das exportações realizadas pela Companhia de Comércio. Saíam de Santiago produtos como o âmbar, cera de abelhas, courama, lã de carneiro, sangue de drago e o anil vegetal. Estes dois últimos produtos, procurados pela indústria têxtil para serem usados como corantes para tingimento, demonstram certa inclinação do arquipélago para a esse tipo de produção, tendo em vista que a urzela sempre fora o principal produto das exportações de Cabo Verde. O anil vegetal, também conhecido com Índigo é fruto da fermentação das folhas de algumas espécies do gênero Indigofera. Já o sangue de drago, produto extraído do dragoeiro, era uma planta endêmica das ilhas atlânticas e sua seiva era transformada em

\footnotetext{
${ }^{73}$ Arquivo do Tribunal de Contas, Livros 4201 a 4204 da Contadoria Geral da África Ocidental, do Maranhão e das Comarcas do Território da Relação da Bahia.
} 
um corante vermelho para tingimento. ${ }^{74}$ Posto isso, a tabela abaixo, ilustra a exportação desses produtos menos expressivos da economia de Cabo Verde:

Tabela II. Gêneros Exportados de Cabo Verde (1756-1778)

\begin{tabular}{|l|r|r|}
\hline Designação & Quantidade & Valor em Lisboa \\
\hline Âmbar & $2,97 @$ & $335 \$ 577$ \\
\hline Anil Vegetal & $46,91 @$ & $1: 035 \$ 345$ \\
\hline Cera de Abelha & $221,78 @$ & $2: 279 \$ 640$ \\
\hline Courama & 7.153 unid. & $1: 303 \$ 190$ \\
\hline Lã de Carneiro & $28,34 @$ & $422 \$ 290$ \\
\hline Sangue de Drago & $5,19 @$ & $\mathbf{5 : 4 4 8} \$ 807$ \\
\hline
\end{tabular}

Fonte: CARREIRA. Op. Cit. 1986. (p.248)

Percebe-se que o volume financeiro movimentado por esses produtos, nos vinte e dois anos de monopólio da Companhia foi bem pequeno: menos de 248\$000, por ano. Levando em conta que a cera de abelha enviada por Cabo Verde - o que representava 41,8\% das exportações do arquipélago - tinha por procedência Bissau e Cacheu, sendo adquirida por comerciantes caboverdianos estabelecidos nos Rios da Guiné e repassados a Companhia, temos que esses gêneros eram menos significativos ainda. Contudo, o mais interessante é que os produtos como o âmbar, o anil vegetal e o sangue de drago eram coletados e processados por escravos da própria empresa monopolista, o que eliminava os intermediários e vedava a extração e manufatura do produto final aos habitantes.

Tal fato corrobora o argumento da insatisfação da atuação da Companhia, já que a empresa limitava cada vez mais a liberdade dos moradores em negociar seus produtos, se recusando a pagar em espécie, tentando manter uma espécie de mercado de trocas entre os gêneros caboverdianos abaixo do preço comumente praticado, pelos

\footnotetext{
${ }^{74}$ SOARES, Fernandes. Dicionário Moderno Ilustrado. Cograe: São Paulo, 1959. Vol. 1 e 3.
} 
manufaturados europeus vindos de Lisboa, superfaturados. Além disso, causava ainda mais descontentamento quando impedia a coleta dos poucos produtos - mesmo os pouco relevantes no âmbito das exportações - já que a própria Companhia cuidava diretamente da produção desses gêneros.

Outro produto que sua coleta e produção eram controladas pela empresa pombalina era urzela. A existência do líquen era sabida desde o início da colonização portuguesa no arquipélago, e embora o alto valor comercial na Europa, teve sua exploração bastante inconstante até meados do século XVIII. Desde o início, sua extração sempre esteve amarrada através de contratos; contudo, entre 1527 e a década de 1730, não há nenhuma menção a sua produção. Começou a chamar a atenção, quando em 07 de novembro de 1730, o capitão-mor de Cacheu Manuel Lopes Lobo em carta, informava a existência da urzela e que os moradores a coletava e vendia aos navios ingleses que aportavam nas ilhas Brava, de São Vicente e São Nicolau. ${ }^{75}$

A ação dos ingleses no arquipélago e as informações sobre os bons preços que o produto tinha na Europa, fez com que a Coroa passasse a pensar em uma melhor forma de controlar a exploração, bem como garantir a boa arrecadação. Sendo assim, retomou-se a política de contrato de arrendamentos: em 1731 havia sido arrematada a apanha da urzela, no valor de $260 \$ 000$ réis pelo período de seis meses; em 1733, no valor de $865 \$ 000$ réis pelo período de três anos; e em 1740 no valor de $4.000 \$ 000$ réis por um período de seis anos. ${ }^{76}$ Já um termo de arrematação de 05 de junho de 1750 , demonstrava que o contrato foi arrematado por um negociante português chamado José Gomes da Silva, por 23 mil cruzados ao ano, por um triênio, o que daria um montante de $9.200 \$ 000$ réis no total. Um aumento de 90,6\% referente aos anos de 1731 a 1734, e de $56,5 \%$ para os seis anos compreendidos entre 1740 e 1745 .

Só esse aumento significativo nas arrematações dos contratos, já demonstraria a importância que a urzela adquiriu como produto de exportação de Cabo Verde. E com a criação da Companhia de Comércio, a produção continuou relevante: é sem dúvidas o principal produto caboverdiano das exportações da empresa monopolista. Na tabela abaixo, vai demonstrada as remessas da erva urzela de Cabo Verde para Lisboa, entre os anos de 1759 e 1779 :

\footnotetext{
${ }^{75}$ SANTOS. Op. Cit. (p. 189)

${ }^{76}$ Idem. (p.190-1)
} 
Tabela III. Exportações de Urzela (1759-1779) - em arrobas

\begin{tabular}{|c|c|c|}
\hline Anos & Quantidade & Valor em Lisboa \\
\hline 1759 & $1.415,91$ & $1: 559 \$ 648$ \\
\hline 1760 & $3.759,50$ & $3: 704 \$ 187$ \\
\hline 1761 & $19.571,66$ & $27: 138 \$ 709$ \\
\hline 1762 & $8.155,97$ & $23: 439 \$ 105$ \\
\hline 1763 & $3.096,13$ & $5: 873 \$ 097$ \\
\hline 1764 & $13.384,78$ & $23: 774 \$ 423$ \\
\hline 1765 & $4.715,66$ & $8: 812 \$ 234$ \\
\hline 1766 & $5.226,59$ & $11: 110 \$ 665$ \\
\hline 1767 & $1.390,88$ & $3: 894 \$ 657$ \\
\hline 1768 & $9.687,56$ & $19: 399 \$ 778$ \\
\hline 1769 & $6.782,97$ & $14: 965 \$ 680$ \\
\hline 1770 & $7.736,97$ & $16: 021 \$ 854$ \\
\hline 1771 & $8.202,06$ & $15: 668 \$ 217$ \\
\hline 1772 & $3.429,09$ & $7: 014 \$ 127$ \\
\hline 1773 & $4.124,09$ & $9: 678 \$ 140$ \\
\hline 1774 & 789,59 & $1: 899 \$ 529$ \\
\hline 1775 & $2.458,38$ & $7: 137 \$ 323$ \\
\hline 1776 & $1.899,25$ & $4: 156 \$ 919$ \\
\hline 1777 & $6.487,34$ & $14: 787 \$ 949$ \\
\hline 1778 & $7.200,72$ & $18: 163 \$ 360$ \\
\hline 1779 & $7.474,53$ & $18: 821 \$ 676$ \\
\hline Total & $126.989,63$ & $257: 021 \$ 277$ \\
\hline
\end{tabular}

Fonte: CARREIRA. Op. Cit. (p.248).

Aqui fica mais evidente ainda, que os produtos demonstrados na Tabela I são realmente parte irrisória das exportações caboverdianas: o valor gerado por esses produtos não chegam a 2,5\%, do valor gerado apenas pelo líquen. A Companhia do Grão-Pará e Maranhão exportou, entre 1759 e 1779, 126.989,63 arrobas de urzela, 
gerando um total de 257:021\$277 réis na praça de Lisboa. Assim sendo, temos que na metrópole, o valor médio era de $2 \$ 024$ réis cada arroba de urzela. Um cálculo para avaliar a lucratividade é possível, já que se possui um resumo geral da erva urzela que foi vendida em Portugal e também exportada entre os anos de 1758 e $1781 .^{77}$ A tabela abaixo mostra esse resumo:

Tabela IV. Urzela vendida em Portugal e exportada (1758 e 1781)

\begin{tabular}{|c|c|c|}
\hline Destino & Arrobas & Valor de Venda \\
\hline \multicolumn{3}{|c|}{ Portugal } \\
\hline Industriais Portugueses & $16.916,78$ & $99: 317 \$ 408$ \\
\hline Real Fábrica de Sedas & 761,69 & $3: 377 \$ 160$ \\
\hline Subtotal & $17.678,47$ & $102: 694 \$ 568$ \\
\hline \multicolumn{3}{|c|}{ Outras metrópoles } \\
\hline Amsterdã & $52.880,19$ & $156: 114 \$ 396$ \\
\hline Gênova & 392,75 & $1: 178 \$ 250$ \\
\hline Londres & $64.584,84$ & $191: 425 \$ 448$ \\
\hline Marselha & $8.295,63$ & $25: 576 \$ 726$ \\
\hline Subtotal & $126.153,41$ & $374: 294 \$ 820$ \\
\hline Total & $143.831,88$ & $476: 989 \$ 388$ \\
\hline
\end{tabular}

Quando se compara a Tabela III e a IV, observa-se que a de número IV abrange três anos que não estão descritos na de número III: os anos de 1758, 1780 e 1781, em que se remeteu a quantidade de 16.842,25 arrobas.Mesmo com essa quantidade a mais no total, ainda é possível calcular a lucratividade, levando em consideração que a Tabela IV demonstra que o valor médio de venda no período foi de $3 \$ 316$ réis a arroba, temos que as 126.989,63 arrobas exportadas entre 1759 e 1779, apontados na Tabela III, resultaria em um valor total de venda de $421.097 \$ 613$ réis: uma notável taxa de lucro de cerca de $61 \%$.

\footnotetext{
${ }^{77}$ Fonte: CARREIRA. Op. Cit. 1986. (p.248).
} 
Outro ponto muito importante que a Tabela IV aponta, é que a maior parte da urzela oriunda do arquipélago de Cabo Verde, entre os anos de 1758 e 1781, foi destinada a outras metrópoles européias,em particular a Holanda e a Inglaterra: $88 \%$ tinha como destino Londres, Amsterdã, Marselha ou Gênova, e apenas 12\% para o Reino. Isso mais uma vez reforça a importância da Revolução Industrial, tendo em vista que $45 \%$ do líquen exportado eram destinados a Inglaterra. O gráfico abaixo ajuda a ilustrar o fato:

Gráfico I. Destinos da Urzela Caboverdiana (1758-1781)

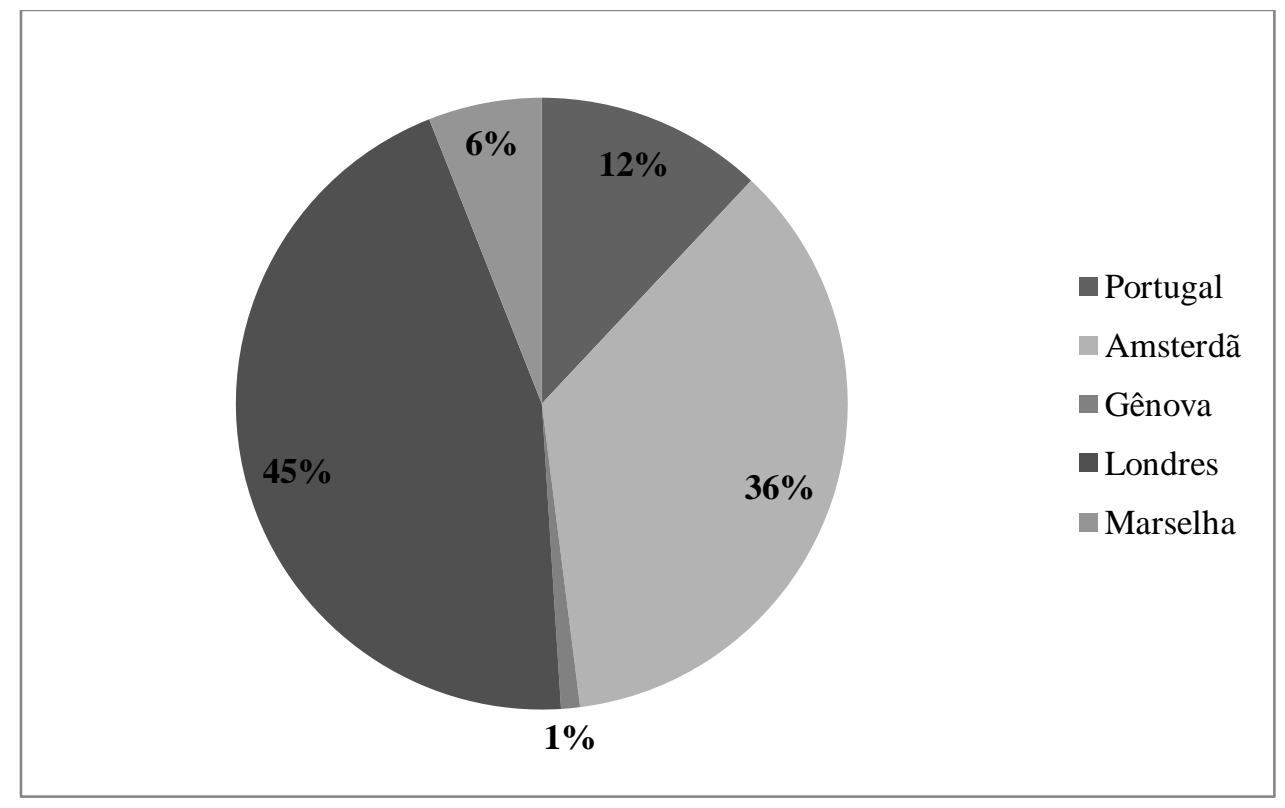

Posto isso, pode-se avaliar também os dados para o período compreendido entre 1790 e 1806. Assim, existe a possibilidade, de avaliar o impacto do fim do monopólio da Companhia de Comércio na produção e comércio da urzela caboverdiana. Utilizando-se dos Borradores do Diário de Cabo Verde e das Balanças de Comércio do Reino de Portugal, fizemos ${ }^{78}$ a seguinte tabela:

\footnotetext{
${ }^{78}$ Arquivo do Tribunal de Contas, Livros 4201 a 4204 da Contadoria Geral da África Ocidental, do Maranhão e das Comarcas do Território da Relação da Bahia.
} 
Tabela V. Urzela Caboverdiana Exportada para Lisboa (1790-1806)

\begin{tabular}{|c|c|c|}
\hline Anos & Quantidade em @ & Valor em Lisboa \\
\hline 1790 & $1.619,05$ & $4: 449 \$ 154$ \\
\hline 1791 & $3.716,06$ & $10: 211 \$ 722$ \\
\hline 1792 & $4.620,28$ & $12: 696 \$ 538$ \\
\hline 1793 & $5.230,00$ & $14: 372 \$ 048$ \\
\hline 1794 & $4.390,77$ & $12: 065 \$ 848$ \\
\hline 1795 & $5.471,58$ & $15: 035 \$ 893$ \\
\hline 1796 & $2.169,58$ & $5: 961 \$ 998$ \\
\hline 1797 & $1.791,56$ & $4: 923 \$ 200$ \\
\hline 1798 & $5.976,29$ & $16: 422 \$ 844$ \\
\hline 1799 & $4.454,00$ & $7: 126 \$ 400$ \\
\hline 1800 & $9.144,00$ & $14: 582 \$ 400$ \\
\hline 1801 & $6.505,00$ & $8: 131 \$ 250$ \\
\hline 1802 & $4.579,00$ & $4: 579 \$ 000$ \\
\hline 1803 & $4.600,00$ & $4: 600 \$ 000$ \\
\hline 1804 & $3.873,00$ & $3: 873 \$ 000$ \\
\hline 1805 & $6.354,50$ & $6: 354 \$ 500$ \\
\hline 1806 & $7.212,00$ & $6: 490 \$ 800$ \\
\hline Total & $81.706,67$ & $151: 876 \$ 595$ \\
\hline
\end{tabular}

Fonte: Arquivo do Tribunal de Contas, Livros 4201 a 4204 da Contadoria Geral da África Ocidental, do Maranhão e das Comarcas do Território da Relação da Bahia.

Percebe-se que no período analisado, já sem o monopólio exercido pela Companhia de Comércio, foram exportadas um total de 81.706,67 arrobas de urzela, resultando no valor de $151.876 \$ 595$ réis. Contudo, no período se assistiu um aumento de $26,3 \%$ no valor médio: enquanto no período da empresa monopolista era de $2 \$ 024$ réis, após o fim do exclusivo comercial subiu para $2 \$ 748$. No que diz respeito aos volumes exportados nos dois períodos, não há uma diferença muito significativa, tendo em vista que a media anual de arrobas, entre 1759 e 1779, foi de 6.349,48 e entre 1790 e 1806 foi de 4.806,27 arrobas: uma queda de 24,3\% na quantidade anual exportada; no 
fim das contas, o aumento do valor médio acabou por amenizar essa queda das remessas.

Já em fins do século XVIII e no início do século XIX, o mercado caboverdiano não oferecia mercadorias muito diversificadas para metrópole, e as exportações eram compostas basicamente de milho e urzela. Algumas outras drogas, como tamarindo, além de alguma carga pequena de tabaco e algodão aparecem, mas que, no entanto, eram irrisórias. Percebe-se pelas Balanças de Comércio que àqueles produtos menos significantes, exportados pela Companhia, simplesmente desaparecem das cargas caboverdianas que chegam à Lisboa. No entanto, as carregações de produtos locais para Lisboa são regulares e, pode-se dizer que importantes, sobretudo, no que diz respeito às remessas de milho. A historiografia já aponta que o abastecimento de cereais sempre foi um dos grandes problemas no Reino e uma remessa anual razoável de milho não era nada desprezível. A tabela abaixo demonstra as remessas de milho entre 1798 e 1806:

Tabela VI. Exportações de Milho para o Reino (1798-1806)

\begin{tabular}{|c|c|c|}
\hline Anos & Quantidade - alqueires & Valor em Lisboa \\
\hline 1798 & 4.762 & $1: 905 \$ 024$ \\
\hline 1799 & 4.227 & $1: 710 \$ 800$ \\
\hline 1800 & 11.040 & $7: 728 \$ 000$ \\
\hline 1801 & 5.684 & $3: 865 \$ 120$ \\
\hline 1802 & 33.069 & 0 \\
\hline 1803 & 0 & $5: 088 \$ 240$ \\
\hline 1804 & 21.201 & 0 \\
\hline 1805 & 0 & $360 \$ 000$ \\
\hline 1806 & 1.200 & $\mathbf{3 0 : 0 2 8} \$ \mathbf{6 8 9}$ \\
\hline Total & $\mathbf{8 1 . 1 8 3}$ & 0529 \\
\hline
\end{tabular}

Fonte: Arquivo Nacional da Torre do Tombo. Série - Balança Geral do Comércio de Portugal (17961830)

A Tabela VInos mostra uma remessa de milho que oscilou muito no período entre 1798 e 1806. Enquanto em 1803 e 1805 não houve nenhuma remessa, em 1802 
foram carregados para Lisboa 33.069 alqueires: mais de $40 \%$ de todo o milho que foi exportado de Cabo Verde. O valor médio de cada alqueire foi de quase $\$ 370$ réis: nesse sentido, foi destinada a Lisboa 81.183 alqueires de milho, resultando em uma importância de 30:028\$689 réis. Pode até não parecer muita coisa em uma primeira vista; contudo, comparando o mesmo período, as remessas de milho são cerca de $40 \%$ do valor das de urzela. Convertendo para quilos, temos que nos dez anos analisados na tabela acima, aferi-se uma quantidade de aproximadamente 63.500 quilos ou 4.325,4 arrobas. É fato que essa quantidade não resolveria os problemas de abastecimento do Reino, mas não se pode negar que não deixa de ser uma quantidade relevante para as proporções e necessidades do período.

Por fim, apresentaremos os dados referentes aos têxteis produzidos no período da Companhia. Apesar de ter de retroceder novamente, os panos caboverdianos foram deixados por último, por serem os produtos mais relevantes para este trabalho: a historiografia e a documentação sugerem que os tecidos são fundamentais para o tráfico de escravos nos Rios da Guiné. Repetidas vezes é visto na documentação, que sem eles não se fazia tráfico. Nesse sentido, procuraremos mostrar as exportações para Bissau e Cacheu, em volume e valor, para estabelecer uma posterior relação com o tráfico nas mesmas feitorias no capítulo seguinte, que trata exclusivamente sobre o comércio de almas nos Rios da Guiné. A opção pelo período da Companhia de Comércio se dá pela limitação das fontes, já que não há dados da exportação desse gênero para a Costa da África para antes ou depois desse recorte.

A empresa mantinha administradores em Cabo Verde e também em Cacheu. O intuito era de fornecer, aos capitães dos navios, as fazendas manufaturadas nas ilhas para o tráfico nos Rios da Guiné. As instruções dos deputados da Companhia em Lisboa, para os capitães dos navios negreiros, deixavam clara a importância dos têxteis para o fomento do negócio de almas: orientavam como servir-se deles tanto no arquipélago, quanto na feitoria de Cacheu. No entanto a importância dos têxteis para o tráfico não se deu apenas no período da Companhia: o Governador de Cabo Verde após 1797, Marcelino António Bastos, elaborou um plano econômico para os têxteis por sugestão do então ministro D. Rodrigo de Sousa Coutinho. Nele, afirma que "na Costa de África, nas Praças de Cacheu e Bissau, estes mesmos panos formam a base do comércio da escravatura que se transporta para o Maranhão e Pará, e mais estimados 
que a moeda corrente, [...] [e] ali recebem um valor dobrado." ${ }^{79}$ Sendo assim, a Tabela VII demonstra a quantidade e o valor dessa panaria enviada para os Rios da Guiné pela Companhia de Comércio, entre os anos de 1758 e 1782:

Tabela VII. Panaria enviada aos Rios da Guiné (1758-1782)

\begin{tabular}{|c|c|c|}
\hline Anos & Quantidade - em peças & Valor nos Rios da Guiné \\
\hline 1758 & 2.280 & $5: 743 \$ 614$ \\
\hline 1759 & 1.551 & $3: 377 \$ 110$ \\
\hline 1760 & 5.579 & $11: 356 \$ 160$ \\
\hline 1761 & 4.067 & $8: 612 \$ 745$ \\
\hline 1762 & 4.399 & $9: 797 \$ 340$ \\
\hline 1763 & 3.116 & $7: 205 \$ 302$ \\
\hline 1764 & 3.799 & $8: 847 \$ 289$ \\
\hline 1765 & 4.354 & $9: 830 \$ 367$ \\
\hline 1766 & 9.887 & $20: 818 \$ 416$ \\
\hline 1767 & 4.912 & $14: 565 \$ 438$ \\
\hline 1768 & 7.760 & $23: 512 \$ 561$ \\
\hline 1769 & 11.338 & $28: 946 \$ 735$ \\
\hline 1770 & 9.878 & $30: 259 \$ 064$ \\
\hline 1771 & 3.862 & $14: 199 \$ 252$ \\
\hline 1772 & 10.487 & $34: 679 \$ 883$ \\
\hline 1773 & 7.948 & $18: 591 \$ 606$ \\
\hline 1774 & 4.281 & $11: 105 \$ 987$ \\
\hline 1775 & 12.759 & $43: 352 \$ 722$ \\
\hline 1776 & 10.155 & $31: 739 \$ 564$ \\
\hline 1777 & 3.723 & $13: 927 \$ 876$ \\
\hline 1778 & 3.219 & $13: 376 \$ 568$ \\
\hline 1779 & 0 & 0 \\
\hline 1780 & 1.376 & $4: 559 \$ 616$ \\
\hline 1781 & 203 & $734 \$ 593$ \\
\hline 1782 & 438 & $2: 097 \$ 142$ \\
\hline TOTAL & 131.371 & $371: 236 \$ 950$ \\
\hline
\end{tabular}

Fonte: CARREIRA. Op. Cit. 1988. (p.251-252)

${ }^{79}$ Plano Econômico do Comércio de panos com a Guiné, ofício no 15 , de 31 de agosto de 1798 Apud CARREIRA, Antônio. Panaria Cabo-Verdiana-Guineense: aspectos históricos e sócio-econômicos. Lisboa: Junta de Investigação do Ultramar, 1968. (p. 28) 
A tabela acima demonstra que a Companhia introduziu nas duas feitorias dos Rios da Guiné um total de 131.371 peças de tecidos, que tinham como compor as mercadorias necessárias para a realização do tráfico de escravos. Toda essa panaria gerou um valor em África, com todos os custos incluídos, de $371.236 \$ 950$ contos de réis. O que daria um valor médio de cerca de $2 \$ 825$ réis, cada pano que era vendido em Bissau ou em Cacheu. Não há informações nos dados analisados que compõem a Tabela VII, que possa auxiliar na especificação do tipo de tecido que foi remetido. Contudo é sabido que os panos destinados para ambas as feitorias, se dividiam em duas categorias: os panos simples e os panos d'obra.

Os panos simples ou singelos, conhecidos tanto no arquipélago, quanto nos Rios da Guiné como barafulas ou panos da terra, eram aqueles cujas bandas eram da cor natural do tecido, ou tingidas grosseiramente de qualquer cor que fosse possível. Existiam alguns tipos, que possuíam algum trabalho de tecelagem bastante grosseira, e que formavam algumas figuras muito simples e que não exigia muita técnica para a produção. Dentre os muitos tipos de panos simples, o que possuía maior demanda na Costa da Guiné era o de tipo ordinário, conhecido também como pano de lei. Eram peças de manufatura grosseira, tingidos de azul, e tinha um preço que variava entre $1 \$ 500$ e $2 \$ 000$ réis. $^{80}$

Os panos d'obra eram peças formadas por bandas que eram manufaturadas apenas em teares, usando apenas linha de algodão branca ou preta, ou também linha de algodão e de seda das mais variadas cores que formavam uma diversidade de figuras geométricas e objetos em relevo. Existiam quatro tipos: bicho simples, bicho cortado, boca branca e oxós, sendo os dois primeiros os que tinham melhor penetração no mercado africano. O bicho simples designava todo o tecido liso nas cores vermelha, amarela e verde, custando entre $2 \$ 000$ e $3 \$ 000$ réis a peça; já o bicho cortado, eram mais bem elaborados, com tecelagem que procurava imitar padrões da pele de alguns animais, e chegavam a custar entre $4 \$ 000$ e $20 \$ 000$ réis cada um. ${ }^{81}$

A Tabela VII também demonstra uma média de 5.250 peças enviadas pela Companhia todos os anos para as feitorias portuguesas na Guiné. E ao que parece, a

\footnotetext{
${ }^{80}$ CARREIRA. Op. Cit. 1968. (p.84 e 88)

${ }^{81}$ Idem (p.95-6).
} 
extinção do monopólio em 1778, não desbaratou a produção têxtil no arquipélago de Cabo Verde. Entretanto, houve notável queda - ao menos no que diz respeito ao final do século XVIII: Bastos no ano de 1798, em seu plano econômico já referido, apontava para uma capacidade produtiva de 2.000 peças anuais, que podiam ser exportadas para a Guiné, a preços que variavam entra $2 \$ 000$ e $4 \$ 000$ réis. $^{82}$

A produção algodoeira já existia em algumas regiões da Alta Guiné antes do contato com os europeus, e tal cultura foi transferida para as ilhas de Santiago, do Fogo e Maio com início da colonização por Portugal e a chegada de escravos vindos da Costa. Mas não só. A tecelagem, mesmo que de maneira rudimentar, também já existia nos Rios da Guiné antes da chegada dos portugueses: alguns povos islamizados já possuíam técnicas para tecer fios e produzir panos; tal atividade também acabou sendo levada ao arquipélago pelos negros escravizados. Nesse sentido, a manufatura de tecidos nas ilhas proporcionou aos moradores locais uma nova atividade econômica, ao mesmo tempo em que modificou a maneira como se fazia tráfico de escravos em Bissau e Cacheu, além de servir de pagamento aos funcionários régios, soldados, entre outros. E nesse sentido, "o algodão e o pano foram incontroversamente umas das mais importantes mercadorias usadas no tráfico",83

O que se discutiu até aqui e é fundamental destacar, é que o arquipélago de Cabo Verde não era apenas uma feitoria lusitana no Atlântico. Mesmo que de forma pouco preocupada e desordenada, é fato que houve uma tentativa de colonização do arquipélago, assim como ocorreu nas demais ilhas Atlânticas. Colonização essa que colapsou em diversos momentos, principalmente devido às intempéries climáticas, que geravam surtos de doenças, fome e altas taxas de mortalidade.E mesmo nesses períodos, tendo em vista a documentação, Portugal sempre manteve um Governador e o mínimo de funcionários e tropas para garantir a presença do Império Português no arquipélago. As secas que resultavam em fomes generalizadas também apontam para $o$ desenvolvimento de uma agricultura local, que era devastada pela falta de chuvas; que se revela também, sobretudo, nas exportações de milho para o Reino no final do século XVIII e nos primeiros anos do XIX. Entretanto, muito mais do que uma colônia

\footnotetext{
${ }^{82} \operatorname{Idem}$ (p.127).

${ }^{83}$ CARREIRA. Op. Cit. 1968. (p.39); SANTOS. Op.cit. (p.203)
} 
portuguesa, devido a sua posição geográfica Cabo Verde acabou se transformando em uma interseção de rotas comerciais: entre Lisboa e as feitorias de Cacheu e Bissau, e entre estas últimas e os portos da América Portuguesa, para onde eram destinados os escravos oriundos dos Rios da Guiné.

Os dados, demonstrados neste capítulo, mostrou que em Cabo Verde houve um comércio relativamente regular com a metrópole a partir de meados da década de 1750. Com a ocupação do arquipélago, Portugal garantia um ponto estratégico para o comércio de escravos, além de assegurara entrada de alguns gêneros que eram demandados na Europa, principalmente à urzela utilizada na coloração de tecidos, em um período onde ainda não existiam corantes sintéticos, no contexto de expansão da indústria têxtil na Europa. Além disso, ainda assegurava o controle de duas praças mercantes para a aquisição de cativos. Isso se deu, em certo sentindo, tendo em vista o desenvolvimento de uma manufatura têxtil nas ilhas, a qual remetia regularmente para a Costa seus tecidos; estes tidos pela documentação e pela historiografia, como fundamentais ao negócio escravista. Tal relação será analisada e discutida de maneira mais aprofundada no capítulo seguinte. 


\title{
CAPITULO II - O TRÁFICO DE ESCRAVOS NOS RIOS DA GUINÉ: AS PRAÇAS DE CACHEU E DE SÃO JOSÉ DE BISSAU
}

\author{
Mas o tráfico de escravos era mais do que \\ um meio para atingir um fim, era também \\ um fim em si mesmo. ${ }^{84}$
}

Neste capítulo, trataremos como se deu a presença portuguesa na região dos Rios da Guiné e como se desenvolveu o tráfico de escravos, buscando analisar seus números em dois períodos históricos distintos: antes e depois da fundação da Companhia de Comércio do Grão-Pará e Maranhão; empresa essa responsável por introduzir escravos africanos, oriundos dessa região, nas capitanias amazônicas da América Portuguesa. Desse modo, para um melhor entendimento do leitor, o capítulo ficou divido em dois tópicos: o primeiro deles, em que será discutido como os portugueses se estabeleceram nas praças de Cacheu e São José de Bissau, bem como funcionavam a administração das feitorias, sua relação com os poderes locais e como era feito o comércio de escravos; no segundo tópico, serão apresentados e discutidos os dados quantitativos referentes ao tráfico de escravos.

\subsection{Os portugueses nos Rios da Guiné}

O contato inicial dos portugueses na região dos Rios da Guiné ocorreu em meados do século XV, com a chegada destes no antigo Reino do Senegal. Chegaram a região no contexto da expansão marítima para o Atlântico, promovida nos tempos do Infante D. Henrique. Destarte estavam interessados nas mercadorias trazidas pelas caravanas transaarianas, estabelecendo-se assim um comércio que integrava as rotas comerciais vindas do interior do continente ao litoral atlântico, em que o foco em um primeiro momento foi o ouro sudanês. Foi nas proximidades das margens dos rios que compõem a bacia hidrográfica da atual Guiné Bissau, que os portugueses irradiaram sua

\footnotetext{
${ }^{84}$ WILLIAMS, Eric. Capitalismo e Escravidão. Rio de Janeiro: Americana, 1975. (p.37)
} 
presença no território denominado por rios da Guiné, visando o comércio de escravos, cera e marfim. ${ }^{85}$

Entende-se por rios da Guiné a região incrustada na Senegâmbia, que se estende da foz do rio Casamansa, na fronteira do atual Senegal com Guiné Bissau, passando pelo rio Cacheu, até a foz dos rios Geba e Corubal - no centro geográfico do território da atual Guiné Bissau - estes que deságuam no Atlântico de fronte ao arquipélago de Bijagós. O primeiro assentamento na região foi próximo a foz do rio Cacheu, que deu nome a feitoria portuguesa ali estabelecida, no final do século XVI; dali difundiu-se no quartel final do século XVII para o Norte estabelecendo-se em Ziguinchor, para o Sul em Bissau, e Farim e Geba sertão adentro: o primeiro margeando o rio Cacheu; o segundo mais ao Sul, flanqueando o rio homônimo. ${ }^{86} \mathrm{O}$ mapa abaixo ilustra a descrição: ${ }^{87}$

\section{Mapa II. Os Rios da Guiné}

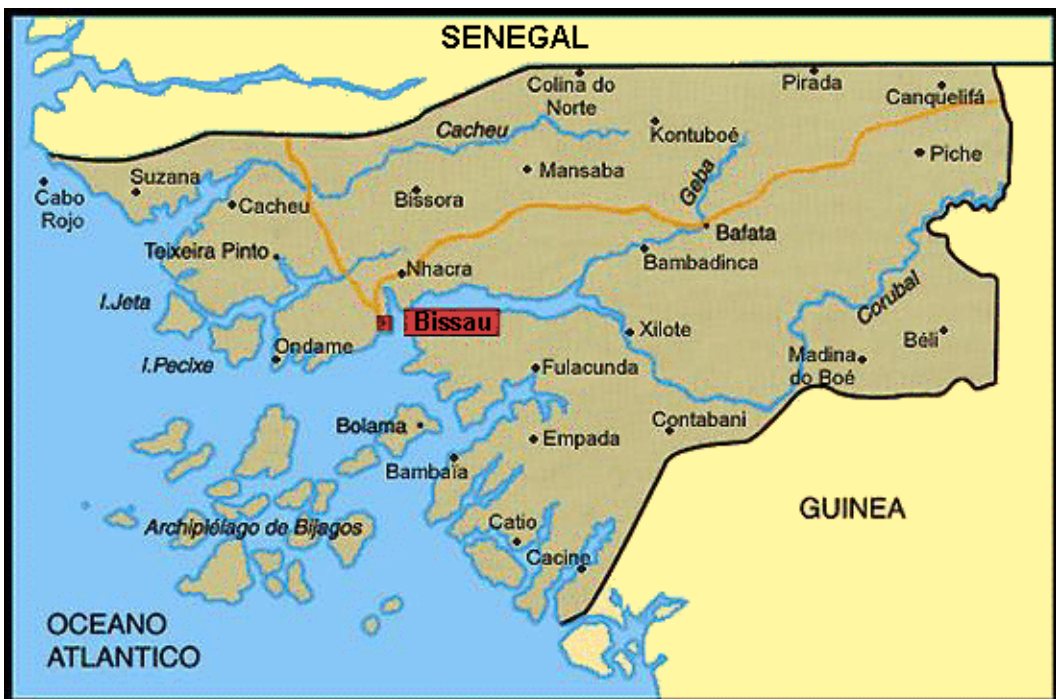

Assim como na empreitada portuguesa às Índias, as feitorias e fortes formarão o núcleo do sistema de ocupação lusitana nos rios da Guiné. Francisco Bethencourt sugeriu que esse modelo havia sido inspirado no sistema utilizado no mediterrâneo pelos mercadores genoveses e venezianos. Contudo, as especificidades locais da costa

\footnotetext{
${ }^{85}$ PERSON, Yves. Os povos da Costa. In: NIANE, Djibril T. (org). História Geral da África - Vol. IV. Brasília: UNESCO, 2010. (p. 339)

${ }^{86}$ LOBBAN JR, Richard A. \& MENDY, Peter Karibe. Historical Dictionary of the Republic of Guinea Bissau. The Rowman\& Littlefield Publishing: Plymouth, 2013. passim

${ }^{87} \mathrm{http}: / /$ www.xpedia1.com/pt/Guinea-Bissau.html. Acesso em 20/08/2014.
} 
africana fizeram com que os portugueses tivessem que adequar esse sistema - assim como ocorreu nas Índias - para assim manter o controle de suas feitorias e conseqüentemente do comércio. Essas adequações vinham, sobretudo, das interações com os poderes locais já estabelecidos. ${ }^{88}$

Durante a primeira metade do século XVIII as feitorias dos rios da Guiné não eram uma prioridade para a Coroa Portuguesa. As duas principais, Bissau e Cacheu, se encontravam em precário estado de conservação: havia apenas um forte, junto à foz do rio Cacheu. Entretanto, a correspondência dos capitães-mores sempre apontava para a necessidade de reformas nas fortificações e o armamento insuficiente para suprir a defesa da presença portuguesa do território guineense. Foi apenas a partir de 1750, que a administração régia começou a perceber a fragilidade do controle lusitano na região e a demonstrar interesse em proteger suas feitorias e entrepostos escravistas. Em 14 de julho de 1751, foi baixado o Decreto Real registrado sob o número 167, ordenando aos governadores da praça de Cacheu e dos portos da Guiné que não admitissem estrangeiros nas feiras e nos portos fazendo comércio; e que se punissem, inclusive os súditos e os africanos, que fossem pegos no trato com os estrangeiros. ${ }^{89}$

Nesse sentido, a coroa portuguesa buscava reproduzir nos rios da Guiné o modelo de regime de exclusivos que já vigia na América Portuguesa, bem como em África, mais especificamente em Angola desde meados do século XVII, quando fora retomada dos holandeses em 1648, pela frota liderada por Salvador Correia de Sá. ${ }^{90} \mathrm{O}$ Decreto Real, referido anteriormente, indicando para uma necessidade de fiscalização mais rigorosa nas feiras do interior e nos portos, a fim de coibir o contrabando - tanto pelos estrangeiros, quanto pelos próprios súditos - nada mais foi que a tentativa prática de garantir o exclusivo comercial, em que os agentes do Império Português da "Praça de Cacheu, e nas mais terras, e portos da Guiné, não admitam, nem consintam daqui por

\footnotetext{
${ }^{88}$ BETHENCOURT. Op. Cit. (p.233).

${ }^{89}$ Arquivo Histórico Ultramarino. Avulsos da Guiné, Caixa 08, documento 06. Decreto Real 167, de 14 de julho de 1751.

${ }^{90}$ LOPES, Gustavo Acioli \& MENZ, Maximiliano M. Resgate e Mercadorias: uma análise comparadado Tráfico Luso-Brasileiro de Escravos em Angola e na Costa da Mina (Século XVIII). In: Afro-Ásia, núm. 37, 2008, (p. 49)
} 
diante estrangeiros alguns nas ditas terras e portos: e que se averigue quais são os que dissimulam, e ainda ajudam a negociar, para serem punidos com exemplar castigo. ${ }^{91}$

A fragilidade do controle na região ficou ainda mais evidente, quando em março de 1751, João Távora - capitão-mor da praça de Cacheu -, registrava a necessidade da construção de uma fortificação na Ilha de Bissau. Geograficamente, Cacheu e Bissau não são muito próximas entre si e a construção de uma fortaleza iria vir de encontro à ação de franceses, que ali se estabeleceram e formaram uma Casa de Comércio. A carta de Távora demonstra também, a impossibilidade de gestão de duas feitorias distantes entre si, por um só responsável, no caso ele próprio. Em resposta, em uma consulta ao Conselho Ultramarino,deu-se parecer favorável para que se tomassem as providências pedidas por Távora.

Mas é somente por volta de 1752, com a chegada do coronel Francisco Roque Sotto Mayor, para substituir Távora - que falecera no ano anterior - que a situação vai começar de fato, a sofrer uma viragem. Sua perspectiva é de que uma ocupação militar e comercial por parte dos franceses era eminente. Ressalta-se ainda o fato de que em 1725 os súditos do Rei Cristianíssimo intentaram construir uma fortaleza em Bissau, que só não foi adiante porque o barco que transportava o material e soldados para guarnecê-la foi a pique logo após lançar-se ao mar. ${ }^{92}$ Nesse sentindo, em carta de 27 de dezembro de 1751, Sotto Mayor, passando ao Reino informações recebidas através dos religiosos estabelecidos em Bissau, deixa claro as intenções francesas:

Que da ilha de Bissau tinham os franceses levado 16 peças de artilharia, e que estando para levar as mais que ainda se acham nas ruínas da antiga fortaleza, se opôs um dos religiosos com o cabo da dita Ilha, os quais com a sua gente armada lhe impediram o seu intento. ${ }^{93}$

E diz mais:

\footnotetext{
${ }^{91}$ Arquivo Histórico Ultramarino. Avulsos da Guiné, Caixa 08, documento 06. Carta do capitão-mor de Cacheu, Sotto Mayor de 15 de dezembro de 1751.

${ }^{92}$ DUARTE, Fausto. Os capitães-mores das praças da Guiné. In: Boletim cultural da Guiné Portuguesa. Vol. VI, no21 (1951), p. 176-220. (p.189)

${ }^{93}$ Arquivo Histórico Ultramarino. Avulsos da Guiné, Caixa 08, documento 26. Ofício do capitão-mor de Cacheu, Sotto Mayor, de 26 de abril de 1752.
} 
E ultimamente afirmam [os religiosos] estar ali a chegar uma ou mais fragatas da Companhia das Índias da dita nação [França], cujo destino se ignora, e somente sabem que no mês de janeiro próximo se há ali achar a dita fragata de guerra e que de algum modo se entende é erigir a fortaleza, porque a um desses padres, disse o comandante francês o ano passado achando-se lá em Bissau, que por causa das guerras não tinha já posto em execução a referida obra. ${ }^{94}$

Sendo assim, Sotto Mayor dedicou esforços para retomar o controle da região. A construção de fortaleza na Ilha de Bissau, solicitada por Távora, foi principiada; assim como as reformas necessárias à fortificação de Cacheu e a igreja da feitoria. Destarte, Sotto Mayor foi o capitão-mor a tocar o projeto de estruturação das feitorias dos rios da Guiné, bem como a tentar estabelecer de fato o controle do comércio português de escravos e outros produtos africanos. Além de tocar a construção e a reforma das feitorias guineenses, ainda elaborou um relatório apontando a quantidade necessária de soldados e de armamento para a defesa efetiva das praças de Cacheu e Bissau. $^{95}$

Além disso, procurou de toda forma estruturar a arrecadação. Os desvios e a falta de pagamentos traziam prejuízos para as feitorias e concomitantemente à Coroa. Na região não havia eficiência alguma por parte da alfândega, o que facilitava o contrabando por parte de africanos e dos próprios súditos, e facilitava a atuação - então proibida pelo Decreto Real de 1751 - dos estrangeiros no comércio. Apontava para uma necessidade de fiscalização mais rigorosa nas feiras do interior e nos portos, a fim de coibir tais ações.

Enquanto Sotto Mayor procurava dar melhor estrutura às duas principais praças portuguesas de comércio da Costa da Guiné, nos outros portos menores como Ianin, Geba e Ziguinchor, a presença portuguesa ainda era mínima. Em requerimento de abril de 1753, Domingos Travessos Genovês, assistente na praça de Ianin, nas redondezas do rio Santo António, solicitava uma companhia de soldados, peças de artilharia, munição e gêneros. Relatou a falta de proteção desse pequeno porto fornecedor de uma boa

\footnotetext{
${ }^{94}$ Arquivo Histórico Ultramarino. Avulsos da Guiné, Caixa 08, documento 26. Ofício do capitão-mor de Cacheu, Sotto Mayor, de 26 de abril de 1752.

${ }^{95}$ Arquivo Histórico Ultramarino. Avulsos da Guiné, Caixa 08, documento 27-A. Ofício do mesmo capitão-mor, de 26 de julho de 1752.
} 
quantidade de escravos acabava prejudicando o comércio: relatou que pouco tempo antes "produzira sem violência trezentos escravos, e outro tanto valor em cera e marfim, gêneros de que abunda em quantidade". ${ }^{96}$.

Nesse sentido, pode-se observar que o domínio português na região era vacilante. A necessidade de controlar as praças da Guiné, a fim de prosperar o controle e os negócios, ao que parece, fez com o capitão-mor Sotto Mayor agisse até com muita hostilidade na região. A ponto do régulo local - chamado Anhanhete Có - enviar carta a D. José I reclamando das atitudes do capitão-mor, que inclusive matara um fidalgo seu; reforçou ainda que estrangeiros não faziam negócios e nem assentavam casas de comércio na região, e que apenas os portugueses tinham permissão para tal ${ }^{97}$.

Tal tensão, entre poderes imperiais e poderes locais, fez com que em novembro de 1753, Nicolau Pina fosse nomeado capitão-mor da praça de Bissau. Os rios da Guiné agora possuíam dois capitães-mores: Sotto Mayor em Cacheu e Pina em Bissau. Contudo, a administração de Bissau ainda estava submetida a de Cacheu. O que se percebe também em tal ação por parte da Coroa, que mais que o reconhecimento aos serviços prestados por Pina, se vê mais uma tentativa de controlaras feitorias e os portos da Guiné. ${ }^{98}$ Além disso, a nomeação de Pina indicou que a presença lusa na região dependia de negociação com os poderes locais. A insatisfação do régulo de Bissau com as atitudes de Sotto Mayor demonstra que, apesar dos portugueses ocuparem os territórios da Costa da Guiné frente às demais coroas da Europa: só era possível manter o comércio, e dar continuidade ao processo de construção da fortaleza, com a colaboração dos poderes locais. Em carta enviada por D. José I a Anhanhete Có, ressaltava que recebeu

[...] na vossa carta uma evidente prova do vosso zelo e fidelidade, e vos agradeço os oferecimentos que me fazeis, e para vos dar provas da atenção que tenho convosco, ordenei ao capitão-mor de Cacheu Francisco Roque Sotto Mayor que não fosse a Bissau, e mando em seu lugar para continuar a reedificação da Fortaleza que houve antigamente sujeita ao meu domínio, o capitão-mor Nicolau Pina, que

\footnotetext{
${ }^{96}$ Arquivo Histórico Ultramarino. Avulsos da Guiné, Caixa 08, documento 48. Ofício de Domingos Traveço Genovês, assistente na praça de Ianin, de 06 de abril de 1753.

${ }^{97}$ Arquivo Histórico Ultramarino. Avulsos da Guiné, Caixa 08, documento 49. Carta do rei de Bissau, Anhanhete Có, de 13 de abril de 1753.

${ }^{98}$ Arquivo Histórico Ultramarino. Avulsos da Guiné, Caixa 08, documento 56. Parecer do Conselho Ultramarino, de 10 de novembro de 1753.
} 
espero vos pressa e toda a atenção e estimação e que em tudo o que se valer de vos lhe deis a ajuda e favor de necessitar o que obrares conducente ao estabelecimento dos meus vassalos na ilha de Bissau, não só para a sua conservação, mas também que sejam preferidos aos das mais nações para o comércio. ${ }^{99}$

Vemos aqui uma diretriz diplomática clara, em que se visava garantir laços de cooperação política e econômica entre os régulos locais, laços estes estabelecidos pelo Império Português nos rios da Guiné, visando garantir uma oferta contínua de escravos, além de assegurar a presença lusa na região. Segundo Bernardino António Álvares Andrade, no que tange a construção da fortaleza, pode-se ainda afirmar que

às instruções superiores que prescreviam uma ação diplomática junto ao régulo da ilha, no sentido de se obter a garantia da tranquilidade do gentio, necessária ao bom andamento dos trabalhos de construção da fortaleza. Além da conveniência decorrente das próprias circunstâncias, esta prevista diligência seguia na esteira das normas por que então habitualmente se guiavam as relações entre os portugueses e os indígenas locais. Já em 1723 tinha sido aproveitada [...] a colaboração do régulo de então na oposição às pretensões dos franceses; e de 1752, bem como de tempos próximos, há notícias ao grande interesse com que a administração central se empenhava em manter uma política de bom entendimento com o régulo da ilha de Bissau. $^{100}$

Outro fato importante que a carta ao rei de Bissau demonstrava - corroborado por decreto real de novembro de 1753 - é que os rios da Guiné agora possuíam dois capitães-mores: Sotto Mayor em Cacheu, e Nicolau Pina em Bissau. Contudo, Bissau ainda estaria subordinada a feitoria de Cacheu. O podemos observar mais a fundo, é que tal nomeação acabava servindo ao reforço da política de exclusivos, já que agora

\footnotetext{
${ }^{99}$ Arquivo Histórico Ultramarino. Avulsos da Guiné, Caixa 08, documento 63. Carta de autor anônimo, de 28 de novembro de 1753.

${ }^{100}$ ANDRADE, Bernardino António Álvares. Planta da Praça de Bissau e suas Adjacentes. Academia Portuguesa de História: Lisboa, 1952. (p.89)
} 
poderia gerir mais de perto ambas as feitorias e melhor controlar os portos da Guiné, de onde as mercadorias das feiras nos sertões para ali fluíam. ${ }^{101}$

Contudo, mesmo mantendo uma política de negociações com os poderes locais e com a construção de uma fortaleza em Bissau, a comunidade portuguesa ali estabelecida enfrentava constantes assaltos e ataques por parte das populações Papel $^{102}$. Outro fato é que apesar de ter estabelecido uma fortaleza em Cacheu desde o final do século XVI, os portugueses não foram capazes de manter os ingleses afastados da Costa. E já no final do século XVII, os franceses já haviam controlado quase a totalidade do comércio na Senegâmbia, com exceção de Bissau e Cacheu. Sendo assim, temos que da quase exclusividade portuguesa no comércio e no tráfico de escravos nos rios da Guiné até meados do XVI, o domínio luso ficou reduzido a duas feitorias e alguns pequenos portos que as orbitavam. ${ }^{103}$ Esse domínio lusitano nas feitorias de Bissau e Cacheu se deu, muito provavelmente pela presença dos lançados ou tangomaos que

[...] ocupavam as terras continentais e misturavam-se, biológica e culturalmente, às populações locais, gerando os Filhos da Terra. Mestiços, filhos de portugueses ou caboverdianos (descendentes de portugueses), esses homens viviam entre mundos, integrando territórios em redes políticas e econômicas pelos interiores do noroeste africano. Herdeiros da língua (transformada pelo uso), religião (autoassumida, embora não necessariamente praticada) católica e da cultura material portuguesa (sobretudo na arquitetura que, embora não necessariamente portuguesa, confrontava com aquela presente na costa antes dos contatos) esses indivíduos se autodenominavam portugueses. ${ }^{104}$

\footnotetext{
${ }^{101}$ Arquivo Histórico Ultramarino. Avulsos da Guiné, Caixa 08, documento 56. Decreto Real 250, de 10 de novembro de 1753.

${ }^{102}$ O povo Papel é um dos 20 grupos étnicos que compõe a população de Guiné-Bissau, compondo cerca de $10 \%$ da população atual do país. Cf: DJALÓ, Tcherno. O Mestiço e o Poder: Identidades, Dominações e Resistências na Guiné. Veja: Lisboa, 2012. (p.58).

${ }^{103}$ Arquivo Histórico Ultramarino. Avulsos da Guiné, Caixa 09, documento 11. Carta do capitão-mor de Cacheu, Sotto Mayor, de 29 de abril de 1755.

${ }^{104}$ MOTA, Thiago Henrique. A Outra Cor de Mafamede: aspectos do islamismo da Guiné em três narrativas Luso-Africanas (1594-1625). Rio de Janeiro: Universidade Federal Fluminense, 2014. (p.12930)
} 
Nesse sentido, a presença desses tangomaos, que se autodenominavam portugueses e se imbuíam no tráfico de escravos e no comércio em geral nos rios e sertões guineenses adentro, foram um fator preponderante para que Portugal conseguisse assegurar o tráfico de escravos em ambas as feitorias. Embora muitas vezes perseguidos por serem acusados de contrabandear escravos aos franceses e ingleses, essa comunidade de mestiços, com suas redes estabelecidas nas feiras do interior, conseguia manter um fluxo de escravos para as feitorias na Costa, garantindo a continuidade do trato na região. ${ }^{105}$ Outro fato é que, a colonização de Cabo Verde possibilitou aos traficantes portugueses, acesso facilitado à panaria produzida no arquipélago, sem a qual não se fazia nenhum tipo de negócio nas feiras das pequenas praças comerciais dos Rios da Guiné, como Geba e Zeguinchor.

Portugal tinha experimentado o controle de cerca de $60 \%$ do tráfico de escravos na região do Senegâmbia até meados do XVI, com as outras potências França e Inglaterra em especial - dividindo-se com o resto. Se somarmos uma centena de anos, entre o início de 1651 e o final de 1750, Portugal não movimentou o número de escravos que havia transportado apenas no primeiro quartel do Seiscentos. É apenas na segunda metade do século XVIII que Portugal irá alcançar e ultrapassar os mesmos níveis do tráfico que realizara na virada do século XVI para o XVII, mas nunca mais sendo principal protagonista. ${ }^{106}$

Isso se deu por uma série de motivos. Dentre eles, o mais importante foi a União das Coroas em 1580, um fator problemático para o domínio ultramarino português. Com os holandeses em guerra contra a dominação castelhana nos Países Baixos, os territórios coloniais conquistados por Portugal, foram constantemente agredidos por parte dos batavos, como por exemplo, nas possessões nas Índias no início do Seiscentos e no Nordeste do Brasil, em Angola e na Costa da Mina no desenrolar do mesmo século.Os estabelecimentos coloniais portugueses, sendo Portugal o elo mais fraco da Coroa Ibérica, sofriam muito mais com a agressão vinda da Holanda. ${ }^{107}$

Mesmo com a Restauração em 1640, a situação econômica e política de Portugal tenderam a aprofundar mais na crise, pois se viu em uma dupla frente de batalha: contra os espanhóis em terra firme - e que até então era seu principal aliado

\footnotetext{
${ }^{105}$ CARREIRA. Op. Cit. passim

${ }^{106}$ Trans-AtlanticSlaveTrade Database, disponível em www.slavevoyages.org.

${ }^{107}$ BOXER, Charles. Império Marítimo Português. São Paulo: Companhia das Letras, 2002. (p.65-6).
} 
contra a Holanda - e contra esta no ultramar, já que os holandeses haviam se estabelecidos em várias feitorias asiáticas, na Costa da Mina e em Angola, então os principais entrepostos de tráfico de escravos dos portugueses em África, e também no Nordeste do Brasil. Com Angola retomada em 1648 e Pernambuco em 1654, o foco português em África voltou-se para a Costa da Mina, que contava com a concorrência holandesa e inglesa no resgate de escravos desde pelo menos o final do século XVII. A concorrência aumentou a importância da região, que nas primeiras décadas do Setecentos tornar-se-ia o principal entreposto do tráfico em África. ${ }^{108}$

Pode-se assegurar nesse sentido, que as prioridades portuguesas em retomar Luanda e se estabelecer na Costa da Mina, fez com que a Senegâmbia fosse relegada ao segundo plano pela Coroa Portuguesa. Desse modo, os dados coletados mostram que só foi por volta de 1754-5 que o tráfico de escravos português começou a expandir novamente nos portos dos rios da Guiné. Em ofício enviado em 29 de abril de 1755, Sotto Mayor apontava que em "Bissau tem dado, desde o ano próximo passado até a presente data, mais quantidade de escravos que nos anos antecedentes, porque daquele porto tem saído o navio de Custódio Ferreira Góis, o da urzela e de outros portugueses com bastante [sic] escravos."

Esse aumento intensificou-se ainda mais com a criação da Companhia Geral do Comércio do Grão-Pará e Maranhão. Entre a primeira e a segunda metade do século XVIII, o volume do negócio na costa da Guiné aumentou em quase nove vezes. Pode-se dizer que para o fomento do negócio em África, a empresa monopolista alcançou o sucesso esperado por Sebastião José de Carvalho e Melo. Mas se serviu bem aos negócios da Coroa e de seus acionistas, o mesmo não se pode dizer das comunidades mercantis portuguesas - formadas também pelos tangomaos - estabelecidas nas feitorias de Bissau e Cacheu.

Os moradores e negociantes estabelecidos nos rios da Guiné fizeram diversas representações contra a Companhia do Grão-Pará e Maranhão. Nessas representações diziam que além de atrapalhar os negócios particulares, também prejudicou a comunicação entre as feitorias na Costa - e também com Cabo Verde, cujos feitores estavam subordinados ao seu Governador. Os administradores da Companhia

\footnotetext{
${ }^{108}$ ACIOLI \& MENZ. Op. Cit. (p.55-6)

${ }^{109}$ Arquivo Histórico Ultramarino. Avulsos da Guiné, Caixa 09, documento 11. Ofício do capitão-mor de Cacheu, Sotto Mayor, de 29 de abril de 1755.
} 
dificultavam a navegação das embarcações menores, responsáveis pelo transporte das cartas e correspondências. Já os comerciantes estabelecidos na praça de Bissau, reclamavam de estarem totalmente impedidos pela empresa fomentista, de irem aos portos da Costa da Guiné fazerem seus negócios. Some-se ao fato, a insatisfação desses mesmos negociantes com os administradores, por pagarem pelos escravos preços muito abaixo, do que supostamente pagariam aos gentios. ${ }^{110}$

Ao que tudo indica, esse grupo de comerciantes estabelecidos nos rios da Guiné, se encontravam ali negociando com portugueses e estrangeiros, pelo menos desde o primeiro quartel do século XVII. Grande parte desses negociantes eram mulatos, frutos da miscigenação entre os primeiros portugueses que chegaram à região, com mulheres africanas e possuíam grande influência na região. Na prática existiam dois tipos de mestiços instalados na costa: aqueles que tinham capital suficiente para se embrenhar no comércio e negociar diretamente com os navios europeus, ou aqueles que se tornavam oficiais ou funcionários das companhias (ou dos próprios comerciantes) que era a grande maioria. E naturalmente os primeiros gozavam de grande influência: os ingleses procuravam muitos desses negociantes em Cacheu no final do século XVII.

Além de atuarem no comércio, os mulatos - na primeira metade do século XVIII - acabaram penetrando também na estrutura política de muitas sociedades africanas, principalmente no interior. Um exemplo disso pode ser observado em um sujeito chamado Tomba Mendez, que era filho do Rei de Barra com uma mulher AfroPortuguesa, um príncipe traficante que atuava como na área de Geba e de Gâmbia, o que demonstra a forte ligação entre os mulatos e o comércio. A presença desses mestiços que falavam o português e comerciavam escravos e outras mercadorias durante o século XVIII, é bastante notada na tradição oral atual de vários povos da região, sobretudo os Bagas e os Susus. ${ }^{111}$

A Companhia do Grão-Pará e Maranhão não vai desbaratar essa rede de mercadores mulatos, estabelecidos na Guiné. A administração da empresa pombalina se sobrepunha aos comerciantes em Cacheu, onde mantinha uma casa de comércio, em que o administrador da Companhia era o responsável direto pelo negócio de escravos. $\mathrm{O}$

\footnotetext{
${ }^{110}$ Arquivo Histórico Ultramarino. Avulsos da Guiné, Caixa 11, documento 07 e 47. Representações dos comerciantes estabelecidos em Bissau, de 05 de março de 1776 e de 29 de julho de 1777.

${ }^{111}$ RODNEY, Walter. A History of the Guinea Coast (1545-1800). Oxford University Press: London, 1970. (p.213).
} 
administrador possuía um estoque dos panos caboverdianos e ele próprio estava imbuído em negociar os escravos vindos das feiras no sertão e destiná-los as embarcações da Companhia que chegavam ao porto. Já em Bissau, o negócio ficava por conta e risco do capitão ou mestre dos navios da empresa pombalinas, os quais precisavam passar por Cabo Verde e carregar-se de panos; de lá rumava para São José de Bissau onde intermediava o negócio e fazia o resgate, e dali partia para os portos amazônicos. ${ }^{112}$

Esse modelo de funcionamento para Bissau fica explícito em carta de 26 de fevereiro de 1760, ao capitão do navio São Sebastião José da Silva Costa. Nas instruções, os administradores da Companhia em Lisboa, dizem a Costa que se dirigisse primeiramente ao arquipélago de Cabo Verde, e que lá procurasse os administradores da empresa: o capitão-mor Pedro Cardozo e João Freire; estes já estavam orientados a fornecer os têxteis necessários para o comércio de escravos em Bissau. Neste porto - de Vila da Praia - a parada devia ser o mais breve possível, apenas para se carregar com os panos e mantimentos para a equipagem e a escravatura. ${ }^{113}$ Chegando a Bissau, o capitão estava incumbido pessoalmente de resgatar os escravos dos comerciantes ali estabelecidos, utilizando os panos que recebera dos administradores de Cabo Verde. ${ }^{114}$

Existia ainda uma hierarquia clara no que diz respeito ao negócio: a carta dizia que caso seja necessário mais panos, deveria solicitá-los ao administrador da Companhia em Cacheu, no caso Manoel Ferreira do Livramento, na sua ausência Duarte José Rodrigues (provavelmente funcionário da empresa) e em último caso ao capitãomor Manoel Pires. Sobrando panos, esses deveriam ser remetidos para Cacheu. O capitão, como principal responsável pelo negócio, deveria se assegurar que arqueação não excedesse o limite e nem estivesse abaixo dele, pois tal fato acarretaria em

\footnotetext{
${ }^{112}$ Arquivo Nacional Torre do Tombo. Fundo: CGGPM; Seção: Junta de Lisboa; Série: Copiadores; Unidade de Instalação: Cartas para Cacheu e Bissau; Referência: PT/TT/CGGPM/A/23/98; Cota: CGGPM, cartas para o Cacheu e Bissau, nº 98. Microfilme 7263.

${ }^{113}$ Esse fato demonstra que durante a atuação da Companhia, as embarcações não tornavam a passar em Cabo Verde, após carregar-se de escravos em Bissau e rumar para a Amazônia. A rota seria Lisboa $\rightarrow$ Cabo Verde $\rightarrow$ Bissau $\rightarrow$ Amazônia.

${ }^{114}$ Arquivo Nacional Torre do Tombo. Fundo: CGGPM; Seção: Junta de Lisboa; Série: Copiadores; Unidade de Instalação: Cartas para Cacheu e Bissau; Referência: PT/TT/CGGPM/A/23/98; Cota: CGGPM, cartas para o Cacheu e Bissau, nº 98. Microfilme 7263. Folhas 5 a 9.
} 
prejuízos, procurando sempre embarcar apenas escravos sadios, que eram os de mais fácil venda. ${ }^{115}$

Instruíam também que caso fosse oferecidos marfim e cera, enquanto se negociavam escravos, deveria comprar tudo o que achar, procurando sempre praticar bons preços. Ressaltavam, contudo, que o negócio principal era o de escravos. Tudo deveria ser realizado no menor tempo possível, procurando rumar logo aos portos amazônicos para evitar gastos e perdas desnecessários. Após desembarcar os escravos no Maranhão ou Pará, o capitão era instruído a carregar com o que for possível de gêneros, para ser transportados ao porto de Lisboa. Também deixava claro que o comércio de gêneros estava sob o regime de exclusivo e vedado a particulares no GrãoPará e Maranhão, e que vigiasse a tripulação com o intuito de não haver nenhum tipo de contrabando. ${ }^{116}$

Já em Cacheu o negócio se dava de maneira um pouco mais simples. Em instrução de 12 de fevereiro de 1760, ao capitão da corveta Nossa Senhora da Esperança, José dos Santos, os deputados da Companhia destacavam que o mesmo deveria observar as seguintes ordens: chegando ao porto de Cacheu, deveria ele próprio procurar o administrador da empresa pombalina Manoel Ferreira de Oliveira, entregando-lhe a carta enviada pela junta da Companhia e fazendo a descarga com a maior brevidade possível. Deveria o capitão ser responsável por carregar a embarcação com a lotação máxima de escravos fornecidos por Oliveira, transportando-os o para o Maranhão ou Grão-Pará, tendo atenção ao cuidado com a escravatura para que houvesse o mínimo de perdas possíveis. ${ }^{117}$

E a carta enviada à Oliveira pelos deputados da Companhia, que fora entregue por Santos, da mesma data, revela ainda mais: a instrução para o dito administrador é que atracando na costa da Guiné, o mesmo deveria tomar as devidas providências com a carregação, e expedir a embarcação com a maior brevidade possível para o Maranhão

\footnotetext{
${ }^{115}$ Arquivo Nacional Torre do Tombo. Fundo: CGGPM; Seção: Junta de Lisboa; Série: Copiadores; Unidade de Instalação: Cartas para Cacheu e Bissau; Referência: PT/TT/CGGPM/A/23/98; Cota: CGGPM, cartas para o Cacheu e Bissau, no 98. Microfilme 7263. Folhas 5 a 9.

${ }^{116}$ Idem.

${ }^{117}$ Arquivo Nacional Torre do Tombo. Fundo: CGGPM; Seção: Junta de Lisboa; Série: Copiadores; Unidade de Instalação: Cartas para Cacheu e Bissau; Referência: PT/TT/CGGPM/A/23/98; Cota: CGGPM, cartas para o Cacheu e Bissau, $n^{\circ}$ 98. Microfilme 7263. Folhas 2 e 3. Já em Cacheu, durante a atuação da Companhia, as embarcações faziam a rota direta da metrópole até a feitoria. A rota seria Lisboa $\rightarrow$ Cacheu $\rightarrow$ Amazônia.
} 
com lotação máxima de escravos. A escravatura ia consignada aos administradores da Cia em São Luís - Francisco Pereira e Vicente Ferreira da Costa. E na embarcação São Pedro, referida anteriormente e que fora traficar em Bissau, do capitão José da Silva Costa, mandou-se:

[...] transportar de Cabo Verde para Cacheu todos os panos que naquelas ilhas se achavam pertencentes a Cia, a fim de se não demorarem mais os navios que deviam seguir na inteligência de que a fim se terá praticado; ordenamos ao capitão desta corveta seja a sua viagem em direitura para esse porto, sem tocar o de Cabo Verde. ${ }^{118}$

Novamente a documentação aponta para a fundamental importância dos têxteis caboverdianos no negócio. Estes chegavam aos rios de Guiné sempre por intermédio das embarcações traficantes, oriundas de Lisboa. E em carta de sete de novembro de 1761, os deputados reforçam aos administradores estabelecidos em Cacheu a importância de manter o fluxo contínuo de panos, bem como para melhorias no processo de manufatura:

É indispensavelmente preciso em esta Companhia a extração dos panos de algodão das ilhas de Cabo Verde assim para a conservação do comércio que tem as mesmas ilhas e suas fábricas como para o pagamento das fazendas que para ali remete a mesma Cia; e ainda que temos feito as mais fortes recomendações para que os moradores dela aperfeiçoem a sua manufatura para os fabricarem da melhor qualidade até o presente senão pode conseguir os efeitos desejados, porém os esperamos pelas diligências que ali devem fazer os administradores em observância das ordens que para o dito exposto lhe continuamos. ${ }^{119}$

E essa importância é recorrente em toda a correspondência do período. Como dito anteriormente, em todas as instruções aos comandantes de embarcação, os panos

\footnotetext{
${ }^{118}$ Arquivo Nacional Torre do Tombo. Fundo: CGGPM; Seção: Junta de Lisboa; Série: Copiadores; Unidade de Instalação: Cartas para Cacheu e Bissau; Referência: PT/TT/CGGPM/A/23/98; Cota: CGGPM, cartas para o Cacheu e Bissau, no 98. Microfilme 7263. Folhas 1 e 2.

${ }^{119}$ Arquivo Nacional Torre do Tombo. Fundo: CGGPM; Seção: Junta de Lisboa; Série: Copiadores; Unidade de Instalação: Cartas para Cacheu e Bissau; Referência: PT/TT/CGGPM/A/23/98; Cota: CGGPM, cartas para o Cacheu e Bissau, nº 98. Microfilme 7263. Folhas 45 a 53.
} 
produzidos no arquipélago são referidos, seja para os navios que iam traficar em Cacheu, seja para os que iam a Bissau. Nas cartas trocadas entre os administradores, também é muito grande a quantidade de menções a importância desses tecidos e o zelo com que tinham que cuidar dos mesmos. O fato é que sem têxteis caboverdianos, é pouco provável que houvesse negócio de escravos, e quase certo que Portugal não garantiria sua presença nos rios da Guiné, já que detinham o controle - mesmo que frágil - do arquipélago de Cabo Verde.

$\mathrm{Na}$ teoria a Companhia também deveria ser responsável pela defesa dos territórios em que monopolizava o comércio, o pagamento dos filhos da folha, controlar os rendimentos das alfândegas e dar continuidade à construção da fortaleza na ilha de São José de Bissau. ${ }^{120}$ Em 1765, novamente a construção se vê entrevada pelo régulo local, como fora no período anterior à chegada da empresa pombalina. Para isso, os deputados da Companhia usam das experiências anteriores, e pede para que o Reverendo Frei Presidente do Hospital dos Religiosos Menores e Formados de Bissau interceda junto aos

régulos [...] de Bissau para que a não embaracem [a fortaleza]. Deseja dever a Vossa Real Majestade o favor de empregar o grande crédito que a suas virtudes se tem conciliado para com os mesmos régulos, persuadindo-os que os fins verdadeiros para que se faz a dita fortaleza não são outros mais, do que para defender e proteger o comércio que desejamos cultivar com eles régulos e seus vassalos; e de se estabelecerem na mesma fortaleza suficientes armamentos para nelas se recolherem as abundantes carruagens que se remeterem deste reino e dos panos que se transportam das ilhas de Cabo Verde, para com eles se fazer o comércio com aquelas recíprocas conveniências dos vassalos do rei nosso senhor e dos mesmos régulos. ${ }^{121}$

Contudo, no que diz respeito à construção da fortaleza, essa é a única vez que o assunto aparece na correspondência da Companhia. Ao analisar, contudo, a correspondência dos funcionários régios estabelecidos nas feitorias de Bissau e Cacheu,

\footnotetext{
${ }^{120}$ SARAIVA, José Mendes da Cunha. A Fortaleza de Bissau e a Companhia do Grão-Pará e Maranhão. Publicações do Arquivo Histórico do Ministério das Finanças: Lisboa, 1947. p. 6 e 9. ANTT: Série Vermelha 5047 (8)

${ }^{121}$ Arquivo Nacional Torre do Tombo. Fundo: CGGPM; Seção: Junta de Lisboa; Série: Copiadores; Unidade de Instalação: Cartas para Cacheu e Bissau; Referência: PT/TT/CGGPM/A/23/98; Cota: CGGPM, cartas para o Cacheu e Bissau, n 98. Microfilme 7263. Folha 161.
} 
o que se observa é uma quase inoperância da empresa relativa ao assunto, que vai perpassar toda a década de 1750 e 1760. Apesar do crescimento do comércio e de alguns avanços na construção da feitoria ocorridos a partir da segunda metade da década de 1760, a praça de Bissau ainda vivia com problemas recorrentes: os nativos faziam assaltos e ataques constantes à feitoria e arredores, em decorrência da falta de um efetivo militar. Sem contar a própria insalubridade do clima e a falta de víveres básicos, que incorriam em um elevado número de doentes e de mortes. ${ }^{122}$

Imbuída de fato no comércio, mas desajustada na defesa da região: é o que parece ser a administração da Companhia do Grão-Pará e Maranhão em África. As agressões dos povos africanos continuaram a ser constantes até o fim do monopólio em 1778. A ponto de a comunicação com Farim, uma praça importante de comércio, ficasse interrompida desde o final de $1775 .{ }^{123}$ Em finais de 1775 e início de 1776, a praça de Cacheu estava sendo atacada sistematicamente pelos gentios dos arredores. Além dessas agressões por parte dos povos locais, outro problema bastante recorrente foi a atuação de contrabandistas estrangeiros. Em carta de fevereiro de 1776, Ignácio Xavier Bayão, capitão-mor de Bissau, relatava que recebeu diversas representações dos negociantes estabelecidos na Ilha dos Bijagós, dizendo que embarcações estrangeiras vindas de Serra Leoa e outras partes da Guiné constantemente perturbavam os negócios “em que os deixava a perder, por serem as compras por preços exorbitantes, os quais preços excediam em ao dobro ao costume."124

Isso evidencia uma disputa acirrada entre os administradores da Companhia e os capitães-mores das praças de Bissau e Cacheu. São recorrentes as reclamações dos capitães em relação às ações dos administradores da empresa, que agiam como bem entendiam e passavam por cima da autoridade régia ali estabelecida; assim como também é recorrente aos administradores, por sua vez, reclamarem da falta de pulso firme dos funcionários régios na tentativa de coibir as sublevações ocorridas. Representavam ainda, dizendo que o negócio da empresa se via prejudicado pelos

\footnotetext{
${ }^{122}$ Arquivo Histórico Ultramarino. Avulsos da Guiné, Caixa 09, documentos 49 e 50 . Ofícios de autoria anônima, de 14 de janeiro de 1766.

${ }^{123}$ Arquivo Histórico Ultramarino. Avulsos da Guiné, Caixa 11, documento 01. Carta de António Vaz de Araújo, de 24 de janeiro de 1776. Caixa 11, documento 41. Do mesmo autor, de 03 de julho de 1777.

${ }^{124}$ Arquivo Histórico Ultramarino. Avulsos da Guiné, Caixa 11, documento 04. Carta do capitão-mor de Bissau, Ignácio Xavier Bayão, de 26 de janeiro de 1776.
} 
diversos assaltos e ataques que ocorriam na costa da Guiné, sobretudo em Geba, que era o principal mercado de escravos da região. ${ }^{125}$

O cenário nos Rios de Guiné, enquanto pólo exportador de mão de obra escrava se resumia em: uma fortaleza inacabada, a aparente pouca preocupação com as condições estruturais das feitorias, da falta de um efetivo de homens e armamentos suficientes para a defesa das possessões. Isso resultava na fragilidade do domínio português e ataques constantes de contrabandistas e de gentios dos arredores. Contudo existia uma preocupação recíproca - da Companhia e dos funcionários régios - em manter os rios que adentravam o sertão, até as feiras, navegáveis. São várias as ordens aos capitães-mores, para que esses removessem ou demolissem pedras e outros obstáculos ao longo dos rios, para que os mesmos fossem mais fáceis de navegar. O que importava, em um primeiro plano, era a manutenção do comércio de escravos e outros gêneros, garantido assim os principais rendimentos das alfândegas guineenses. A defesa de território ia se garantindo através do embaraço ao contrabando, o que não deixa de ser uma proteção a jurisdição portuguesa na Guiné. ${ }^{126}$

E dos fins do século XVIII até o início do século XIX, as correspondências oficiais, trocadas entre administradores régios e a metrópole, só refletem o que era remetido anteriormente. O que se pode perceber é que os portugueses, estabelecidos nas feitorias africanas, procuraram costurar alianças diplomáticas com determinados povos africanos, para a defesa dos estabelecimentos portugueses na Costa. Sempre que eram atacados ou assaltados por determinados grupos, pediam socorro aos "reis amigos", na tentativa de defesa e revide desses constantes ataques. $\mathrm{O}$ que se percebe, nesse sentido, é que o poder do Império Português nesta região da África era muito fluido e dependia dessas alianças para sobreviver.

Contudo, o que se percebe é que mesmo com tantas reclamações e requerimentos enviados pelos capitães estabelecidos nas feitorias, a situação pouco mudou em relação a meados do século XVIII. As praças se encontravam em estado de abandono, com gentios atacando sistematicamente as feitorias e contrabandistas estrangeiros atuando quase que livremente. Em várias correspondências enviadas ao

\footnotetext{
${ }^{125}$ Arquivo Histórico Ultramarino. Avulsos da Guiné, Caixa 11, documento 51. Carta do capitão-mor de Bissau, Ignácio Xavier Bayão, de 25 de dezembro de 1777.

${ }^{126}$ Arquivo Histórico Ultramarino. Avulsos da Guiné, Caixa 11, documento 16. Ofício do mesmo capitãomor, de 05 de julho de 1776.
} 
Reino no ano de 1802, o capitão-mor de Cacheu José Joaquim de Souza Trovão, apontava para o estado de ruína e do total abandono da Praça de Cacheu e que Igreja se encontrava parcialmente destruída. Dizia ainda que faltava dinheiro para pagamento dos filhos da folha, pois pouco se arrecadavam e muitos navios, aportavam nos portos vizinhos, como o de Farim, no intuito de não pagar os direitos em Cacheu. Além disso, não tinha condições de socorrer a praça de Ziguinchor, que se encontrava em guerra com dois reinos vizinhos, por falta de pólvora, armamento e homens. ${ }^{127}$

No ano seguinte, a falta de uma administração e defesa eficientes, permitiu novamente que os estrangeiros atuassem de maneira efetiva. Sobretudo ingleses, que atravessavam os negociantes portugueses ali estabelecidos, pois passaram a introduzir novos e mais variados manufaturados europeus no mercado africano, tais como tabaco, tecidos, armas entre outros. Nesse sentindo, conseguiam resgatar escravos, cera e marfim com maior facilidade e prejudicava no primeiro momento os comerciantes estabelecidos nas feitorias, tendo em vista que não tinham acesso aos mesmos produtos que os ingleses traziam; e em segundo momento, a própria Real Fazenda que deixava de recolher os devidos direitos de alfândega. ${ }^{128}$

Nesse sentido, percebe-se que o discurso no transcorrer da segunda metade do século XVIII nunca mudou. As correspondências oficiais demonstram como a zona de tráfico dos rios de Guiné, era completamente marginal e que recebera pouca atenção por parte da Coroa. Mesmo com alguns raros estímulos, como a Companhia, a região pouco se desenvolveu e a presença portuguesa sempre foi exígua. Mas de certa forma, através das alianças de cooperação política estabelecidas com poderes locais, e pela facilidade com que os portugueses se infiltravam e se misturavam com as sociedades africanas, conseguiu garantir certo controle - mesmo que frágil - desse mercado escravista.

Em alguns balanços de receitas e despesas das feitorias dos rios da Guiné, enviados à Corte, pode-se evidenciar melhor ainda, como se estruturou a ocupação dessas regiões: o fundamental não era a colonização do espaço e desenvolvimento de uma economia vigorosa, mas sim garantir a oferta do produto mais lucrativo e essencial

\footnotetext{
${ }^{127}$ Arquivo Histórico Ultramarino. Avulsos da Guiné, Caixa 16, documentos 38, 41 e 50. Cartas do capitão-mor de Cacheu, José Joaquim de Souza Trovão, de 03 de fevereiro de 1802, de 05 de fevereiro de 1802 e de 09 de junho de 1802.

${ }^{128}$ Arquivo Histórico Ultramarino. Avulsos da Guiné, Caixa 17, documento 06. Carta de autor não identificado, de 29 de julho de 1803.
} 
para manter a empresa colonizadora portuguesa na América: os escravos. Nos balanços vemos que as despesas se resumiam a três itens principais: o primeiro, o pagamento de filhos da folha, ou seja, soldos, côngruas e ordenados dos soldados, religiosos e funcionários civis respectivamente; em segundo lugar, despesas com o hospital, mantido pelos religiosos; e por fim, mantimentos em geral, sobretudo gado bovino e suíno vindos de Cabo Verde e de arroz. O fato de ter que comprar mantimentos, demonstra que não havia uma preocupação em desenvolver produção alguma na região. A manutenção das tropas e da própria comunidade comercial, bem como do tráfico de escravos, dependia quase que exclusivamente, das remessas caboverdianas, de alguma produção das próprias comunidades guineenses e um ou outro produto remetido da metrópole. $^{129}$

Até aqui, pode-se compreender como foi o estabelecimento das feitorias portuguesas nos Rios da Guiné, bem como funcionou sua administração, suas relações sociais e como se procurou estruturar os negócios referentes ao tráfico de escravos e outros gêneros ofertados pelo mercado africano. No tópico a seguir, serão demonstrados os resultados quantitativos obtidos pelo mercado guineense no tráfico de escravos português.

\subsection{O Tráfico de Escravos nos Rios da Guiné: um estudo quantitativo}

De fato, o recorte temporal deste trabalho circunscreve os anos de 1756 a 1807. No entanto, julgou-se necessário, ao analisar os dados referentes ao tráfico de escravos, a necessidade de retroceder desde o início das viagens negreiras com destino aos Rios da Guiné. Isso se fez preciso, para que se pudesse compreender como se adequou e se estruturou o negócio na região, bem como observar como se comportou a flutuação do comércio de almas na longa duração. Outro fator, esse mais preponderante ao trabalho, foi o de tentar avaliar o impacto quantitativo da criação da Companhia Geral do Comércio do Grão-Pará e Maranhão no trato negreiro, assim como seus desdobramentos.

\footnotetext{
${ }^{129}$ Arquivo Histórico Ultramarino. Avulsos da Guiné, Caixa 14, documento 56. Balanço das contas de Bissau e Cacheu entre julho de 1791 a maio de 1793, de 01 de outubro de 1793.
} 
A primeira viagem de que se tem registro, em que foram remetidos escravos oriundos do complexo escravista formado pelo arquipélago de Cabo Verde e das feitorias dos Rios da Guiné é datada de 1526. Foi uma embarcação espanhola, cujo proprietário era chamado de Esteban Carrega. Foram embarcados 101 escravos das ilhas de Cabo Verde, com destino à ilha de Cuba onde foram desembarcadas 75 peças sobreviventes da travessia atlântica. ${ }^{130}$ A partir dessa primeira viagem foram realizadas outras 721; e nesse sentido, temos que para o período compreendido entre 1526 e 1807, dividido em períodos de 25 anos, a seguinte quantidade de escravos foi embarcada de Cabo Verde e dos Rios da Guiné:

Tabela VIII. Escravos Embarcados em Cabo Verde e Rios da Guiné (1526-1807)

\begin{tabular}{|c|r|r|r|r|r|}
\hline Anos & Bissau & Cacheu & $\begin{array}{r}\text { Guiné } \\
\text { Portuguesa }\end{array}$ & $\begin{array}{r}\text { Cabo } \\
\text { Verde }\end{array}$ & Total \\
\hline $1526-1550$ & 0 & 0 & 0 & 11.157 & $\mathbf{1 1 . 1 5 7}$ \\
\hline $1551-1575$ & 0 & 0 & 268 & 1.087 & $\mathbf{1 . 3 5 5}$ \\
\hline $1576-1600$ & 0 & 0 & 11.833 & 8.548 & $\mathbf{2 0 . 3 8 1}$ \\
\hline $1601-1625$ & 0 & 920 & 12.436 & 6.669 & $\mathbf{2 0 . 0 2 5}$ \\
\hline $1626-1650$ & 0 & 4.007 & 3.760 & 1.807 & $\mathbf{9 . 5 7 4}$ \\
\hline $1651-1675$ & 0 & 2.251 & 395 & 2.584 & $\mathbf{5 . 2 3 0}$ \\
\hline $1676-1700$ & 948 & 945 & 0 & 2.974 & $\mathbf{4 . 8 6 7}$ \\
\hline $1701-1725$ & 456 & 2.364 & 0 & 438 & $\mathbf{3 . 2 5 8}$ \\
\hline $1726-1750$ & 1.243 & 4.227 & 0 & 876 & $\mathbf{6 . 3 4 6}$ \\
\hline $1751-1775$ & 12.055 & 10.240 & 0 & 1.410 & $\mathbf{2 3 . 7 0 5}$ \\
\hline $1776-1800$ & 19.196 & 10.306 & 649 & 370 & $\mathbf{3 0 . 5 2 1}$ \\
\hline $1801-1807$ & 8.746 & 3.163 & 882 & 1.590 & $\mathbf{1 4 . 3 8 1}$ \\
\hline Total & $\mathbf{4 2 . 6 4 4}$ & $\mathbf{3 8 . 4 2 3}$ & $\mathbf{3 0 . 2 2 3}$ & $\mathbf{3 9 . 5 1 0}$ & $\mathbf{1 5 0 . 8 0 0}$ \\
\hline
\end{tabular}

Fonte: The Trans-Atlantic Slave Trade Database. Disponível em www.slavevoyages.org. Filtros utilizados: Time frame > 1514 a 1807; Principal place of slave purchase > Bissau, Cacheu, Portuguese Guinea, Cape Verde Islands

\footnotetext{
${ }^{130}$ Fonte: The Trans-Atlantic Slave Trade Database. Disponível em www.slavevoyages.org. Filtros utilizados: Time frame > 1514 a 1807; Principal place of slave purchase > Bissau, Cacheu, Portuguese Guinea, Cape Verde Islands. Viagem de número 11.298.
} 
A partir da possível "viagem inaugural" de Carrega, a tabela demonstra que das já citadas 721 viagens realizadas a partir de Cabo Verde e Rios da Guiné, foram embarcados e transportados 150.800 escravos originários de São José de Bissau, Cacheu, Guiné Portuguesa e Cabo Verde. Também é possível perceber, que desde o início das viagens, apenas o arquipélago caboverdiano remeteu escravos em todos os períodos ilustrados. Contudo, cabe uma ressalva: pode-se assegurar tranquilamente que dessas 39.510 peças que têm origem de partida nas ilhas, não são de escravos nativos. Ressalta-se que Cabo Verde era desabitado antes da chegada portuguesa e sempre possuiu pequena população e como fora concebido como um entreposto do tráfico, nesse sentido a maior parte - para não falar na totalidade - dos escravos tinha origem na Senegâmbia. Contudo, as fontes não permitem aferir a origem exata desses africanos remetidos do arquipélago. Desse modo, o gráfico abaixo demonstra a participação de cada feitoria no trato:

\section{Gráfico II. Participação das Feitorias no Tráfico de Escravos (1526-1807)}

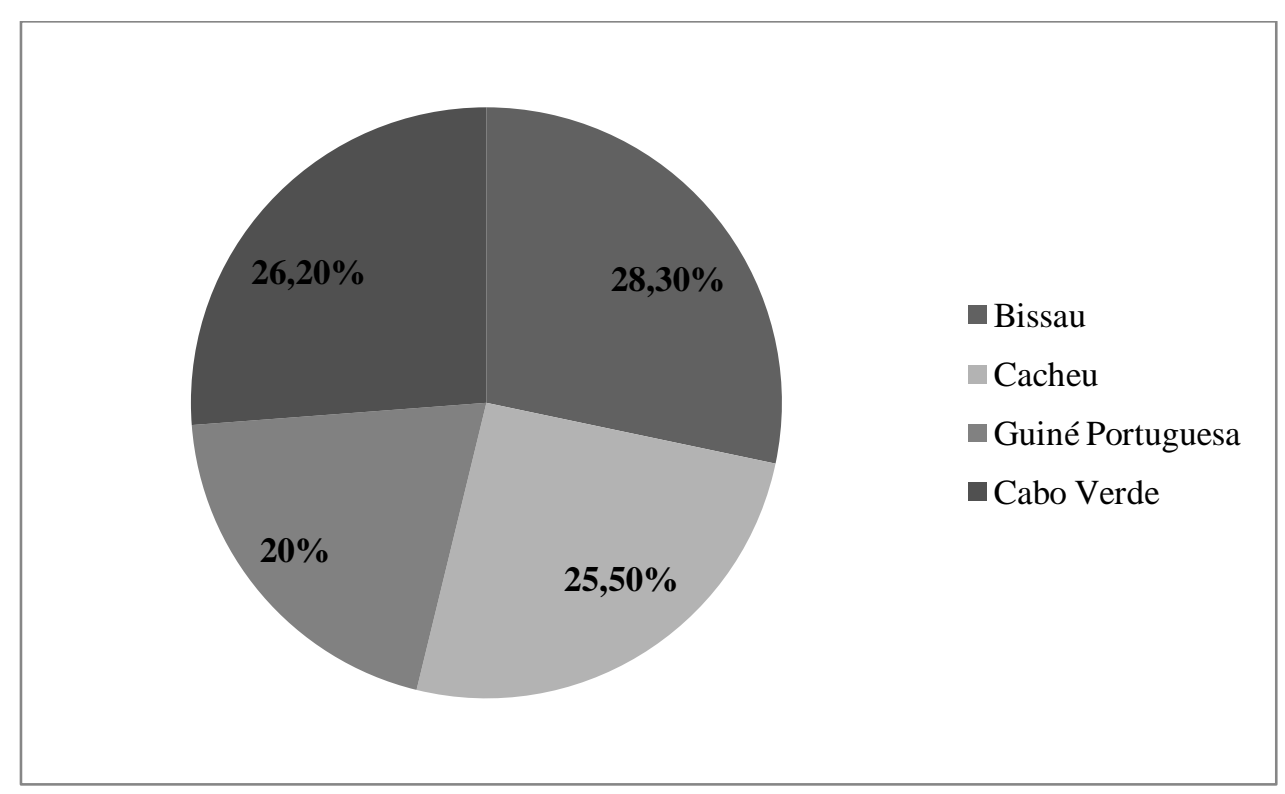

Assim sendo, temos que no período compreendido entre 1526 a 1807 foram remetidos da feitoria de Bissau 28,3\% dos escravos, ou 42.644 peças, o que a tornou a que mais exportou africanos oriundos de Cabo Verde e dos Rios da Guiné; na sequência vem o entreposto comercial de Cabo Verde, com 26,2\% das exportações, ou 39.510 escravos; a seguir vêm a feitoria de Cacheu, com 25,5\% dos escravos remetidos, ou 38.423 peças; e por fim vem a Guiné Portuguesa, que seriam outros portos menores que 
orbitavam os Rios da Guiné, com $20 \%$ das remessas, ou 30.233 escravos. Do ponto de vista dos escravos desembarcados nos portos coloniais e metropolitanos, temos que:

Tabela IX. Escravos Desembarcados nos Portos Coloniais da América e nos Portos Metropolitanos (1526-1807)

\begin{tabular}{|c|r|r|r|r|r|r|r|r|}
\hline Anos & Europa & $\begin{array}{r}\text { América } \\
\text { do Norte }\end{array}$ & Caribe & $\begin{array}{r}\text { América } \\
\text { Espanhol } \\
\mathbf{a}\end{array}$ & $\begin{array}{r}\text { América } \\
\text { Portugue } \\
\text { sa }\end{array}$ & $\begin{array}{r}\text { África } \\
\text { Outros }\end{array}$ & Total \\
\hline $1526-1550$ & 0 & 0 & 277 & 137 & 0 & 0 & 420 & 834 \\
\hline $1551-1575$ & 0 & 0 & 555 & 800 & 0 & 0 & 0 & $\mathbf{1 . 3 5 5}$ \\
\hline $1576-1600$ & 0 & 0 & 193 & 19.952 & 0 & 236 & 0 & $\mathbf{2 0 . 3 8 1}$ \\
\hline $1601-1625$ & 120 & 0 & 708 & 18.961 & 0 & 0 & 236 & $\mathbf{2 0 . 0 2 5}$ \\
\hline $1626-1650$ & 0 & 0 & 570 & 7.093 & 1.121 & 0 & 432 & $\mathbf{9 . 2 1 6}$ \\
\hline $1651-1675$ & 338 & 0 & 779 & 1.197 & 0 & 0 & 700 & $\mathbf{3 . 0 1 4}$ \\
\hline $1676-1700$ & 0 & 0 & 1.281 & 800 & 1.158 & 0 & 0 & $\mathbf{3 . 2 3 9}$ \\
\hline $1701-1725$ & 182 & 235 & 108 & 0 & 2.672 & 0 & 0 & $\mathbf{3 . 1 9 7}$ \\
\hline $1726-1750$ & 531 & 83 & 438 & 0 & 2.822 & 0 & 0 & $\mathbf{3 . 8 7 4}$ \\
\hline $1751-1775$ & 871 & 0 & 1.450 & 0 & 19.016 & 0 & 0 & $\mathbf{2 1 . 3 3 7}$ \\
\hline $1776-1800$ & 0 & 0 & 0 & 0 & 29.273 & 0 & 0 & $\mathbf{2 9 . 2 7 3}$ \\
\hline $1801-1807$ & 0 & 0 & 237 & 0 & 13.224 & 0 & 0 & $\mathbf{1 3 . 4 6 1}$ \\
\hline Total & $\mathbf{2 . 0 4 2}$ & $\mathbf{3 1 8}$ & $\mathbf{6 . 5 9 6}$ & $\mathbf{4 8 . 9 4 0}$ & $\mathbf{6 9 . 2 8 6}$ & $\mathbf{2 3 6}$ & $\mathbf{1 . 7 8 8}$ & $\mathbf{1 2 9 . 2 0 6}$ \\
\hline
\end{tabular}

Fonte: The Trans-Atlantic Slave Trade Database. Disponível em www.slavevoyages.org. Filtros utilizados: Time frame > 1514 a 1807; Principal place of slave purchase > Bissau, Cacheu, Portuguese Guinea, Cape Verde Islands.

Temos que dos 150.800 escravos que foram embarcados em África, 129.206 sobreviveram à viagem de travessia Atlântica, ou 21.594 peças não chegaram vivas aos seus portos de destino: um índice de mortalidade de cerca de $14,3 \%$, no período compreendido entre 1526 e 1807. Outro fato importante que a tabela demonstra, são os mercados importadores mais importantes: a América Portuguesa e a Espanhola. O gráfico abaixo ilustra melhor o fato: 


\section{Gráfico III. Participação dos Mercados nas Importações de Escravos (1526-1807)}

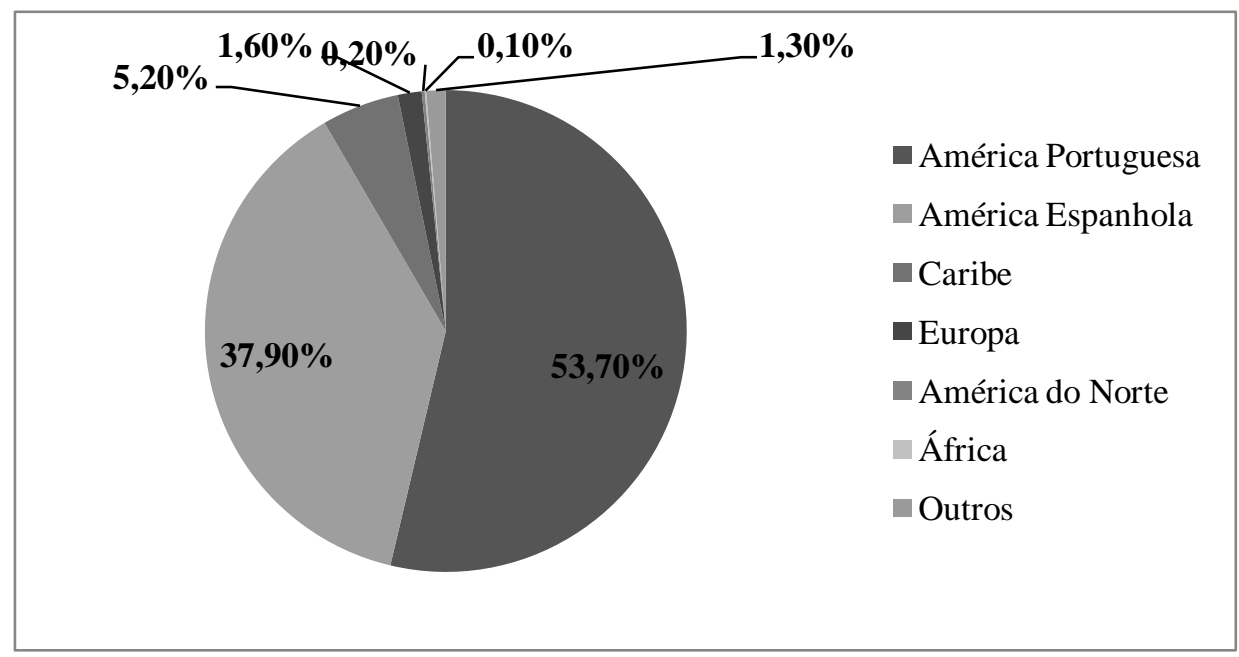

Temos que mais da metade dos escravos oriundos dos Rios da Guiné foram destinados à América Portuguesa: 53,7\%, ou 69.286 dos escravos; o segundo mercado que mais recebeu escravos da região foi a América Espanhola, com 37,9\% dos escravos desembarcados, ou 48.940 peças; a seguir, tem-se o Caribe com 5,2\% da escravaria importada, ou 5.596 escravos. Outros portos da América do Norte, Europa, África e não especificados somam $3,2 \%$ dos africanos remetidos e desembarcados, ou 4.384 peças importadas.

Contudo, apesar da grande quantidade de escravos recebidos nos portos da América Espanhola, a tabela nos mostra que só houve entradas até o fim do século XVII. Nesse sentido, temos que desde o Quinhentos o Império Espanhol passou a conceder uma série de asientos a comerciantes portugueses, e "não há dúvida que o súbito incremento do imenso mercado das Índias Ocidentais mudou o rumo da escravatura" para as possessões de Castela. ${ }^{131}$ No período compreendido entre 1580 e 1640, com a União das Coroas Ibéricas, seria natural que a Monarquia Espanhola procurasse enviar o maior número de escravos para suas colônias americanas. E no período pós-Restauração, como foi descrito no primeiro capítulo desta obra, a Coroa Portuguesa abriu o tráfico aos navios espanhóis desde que negociassem escravos com ouro, prata ou têxteis.

\footnotetext{
${ }^{131}$ LOPES, Edmundo Correia. A Escravatura: Subsídios para a sua História. Lisboa: Antígona, 1944. (p.28)
} 
Todavia, apesar dessa proeminência castelhana nos séculos XVI e XVII, a Tabela também revela uma viragem do tráfico no século XVIII: é a colônia portuguesa que passou a ter prioridade nas exportações de escravos; percentualmente falando, temos que $94 \%$ da escravaria oriunda dos Rios da Guiné, foram remetidos as possessões lusitanas na América no século XVII. Posto isso, sabendo da importância da América Espanhola para as exportações de escravos guineenses nos séculos XVI e XVII e da América Portuguesa para o tráfico de almas no XVIII, é relevante procurar dividir essas entradas por século:

Tabela X. Escravos Embarcados e Desembarcados divididos por Séculos

\begin{tabular}{|c|c|c|c|}
\hline Séculos & Embarcados & Desembarcados & Mortandade \\
\hline Século XVI & 32.893 & 22.570 & $31,4 \%$ \\
\hline Século XVII & 39.696 & 35.494 & $11,4 \%$ \\
\hline Século XVIII & 78.211 & 71.142 & $9,1 \%$ \\
\hline Total & $\mathbf{1 5 0 . 8 0 0}$ & $\mathbf{1 2 9 . 2 0 6}$ & - \\
\hline
\end{tabular}

Fonte: The Trans-Atlantic Slave Trade Database. Disponível em www.slavevoyages.org. Filtros utilizados: Time frame > 1514 a 1807; Principal place of slave purchase > Bissau, Cacheu, Portuguese Guinea, Cape Verde Islands.

O que se percebe é que o século XVIII foi o grande ápice do tráfico de escravos nos Rios da Guiné. De toda a escravaria embarcada, no período entre 1526 e 1807, só no Setecentos foram embarcados $51 \%$ de todos os africanos de Bissau, Cacheu e Cabo Verde; dos desembarcados a fatia é ainda maior: 55\%. Isso porque, como a própria tabela demonstra, o índice de mortalidade caiu de maneira expressiva. De gritantes $31,4 \%$ no século XVI, para $11,4 \%$ no XVII e por fim para 9,1\% no XVIII. Uma taxa de mortalidade um pouco abaixo, se comparado às outras rotas de tráfico português, que girava em torno de $10 \%$.

Sendo assim, essa análise do tráfico de escravos no complexo Cabo Verde e Rios da Guiné na longa duração, serviu para demonstrar alguns pontos importantes. Pode-se dividir o negócio negreiro na Costa da Guiné em dois momentos distintos: o primeiro dele, que perpassou os séculos XVI e XVII, em que o comércio de almas esteve voltado para a América Espanhola, através de asientos concedidos; e o segundo 
momento, durante o século XVIII, em que o negócio sofre uma viragem e os escravos, oriundos das feitorias dos Rios da Guiné, passaram a ser exportados quase que exclusivamente para América Portuguesa.

Outro ponto importante, para este trabalho, é justamente o fato do ápice desse tráfico de escravos ocorrer justamente no século XVIII, tendo a colônia lusitana na América como principal mercado recebedor de mão de obra africana. Isso porque o intuito aqui é tentar compreender o comércio escravista nos Rios da Guiné no âmbito da economia atlântica portuguesa na segunda metade da referida centúria. Nesse sentido, é importante analisar o movimento do tráfico durante todo o Setecentos, para melhor compreender a relevância que o negócio vai alcançar na segunda metade do século, com a criação da Companhia Geral do Comércio do Grão-Pará e Maranhão no ano de 1756.

Nesse sentido, a tabela abaixo demonstra o movimento do tráfico de escravos no período compreendido entre 1701 e 1807; dividiu-se em dois períodos: no antes e depois da criação da empresa monopolista, com o intuito de avaliar seu impacto no tráfico de escravos na região dos Rios da Guiné. Os dados referentes ao negócio negreiro foram distribuídos por qüinqüênios.

Como se pode verificar, foram embarcados em África 78.211 escravos entre 1701 e 1807. Neste período analisado, temos uma média geral de 730,9 escravos, que iam a bordo dos navios negreiros, por ano. Fato ainda mais relevante quando se analisa as exportações de escravaria antes e depois da criação da Companhia: no período entre 1756 e 1807, foram embarcados quatro vezes mais escravos do que na primeira metade do século XVIII. Dos mais de 78 mil escravos remetidos pelos Rios da Guiné, 64.371 foram embarcados após o ano de 1756, quando passou a vigorar o monopólio da empresa comercial: ou seja, $82,3 \%$ de toda a escravaria transportada no século XVIII, se deu apenas na segunda metade do Setecentos. O que se apreende desses dados é que em apenas 22 anos de funcionamento, a Companhia foi à ponta de lança por quadruplicar 0 comércio de almas na região, em relação a um período de 55 anos anteriores. 
Tabela XI. Escravos Embarcados (1701-1807)

\begin{tabular}{|c|c|c|c|c|c|}
\hline Anos & Bissau & Cacheu & $\begin{array}{c}\text { Guiné } \\
\text { Portuguesa }\end{array}$ & Cabo Verde & Total \\
\hline $1701-1705$ & 0 & 130 & 0 & 0 & 130 \\
\hline $1706-1710$ & 0 & 0 & 0 & 0 & 0 \\
\hline 1711-1715 & 0 & 714 & 0 & 81 & 795 \\
\hline $1716-1720$ & 61 & 593 & 0 & 330 & 984 \\
\hline $1721-1725$ & 395 & 927 & 0 & 27 & 1.349 \\
\hline 1726-1730 & 39 & 0 & 0 & 0 & 39 \\
\hline 1731-1735 & 0 & 584 & 0 & 11 & 595 \\
\hline $1736-1740$ & 766 & 1.204 & 0 & 100 & 2.070 \\
\hline 1741-1745 & 331 & 1.754 & 0 & 300 & 2.385 \\
\hline $1746-1750$ & 107 & 685 & 0 & 465 & 1.257 \\
\hline $1751-1755$ & 2.098 & 1.500 & 0 & 638 & 4.236 \\
\hline Subtotal & 3.797 & 8.091 & 0 & 1.952 & 13.840 \\
\hline $1756-1760$ & 1.121 & 1.787 & 0 & 212 & 3.120 \\
\hline $1761-1765$ & 2.238 & 2.370 & 0 & 0 & 4.608 \\
\hline $1766-1770$ & 3.705 & 2.421 & 0 & 2 & 6.128 \\
\hline $1771-1775$ & 2.893 & 2.162 & 0 & 558 & 5.613 \\
\hline $1776-1780$ & 3.882 & 1.962 & 0 & 7 & 5.851 \\
\hline $1781-1785$ & 3.473 & 1.516 & 0 & 0 & 4.989 \\
\hline $1786-1790$ & 3.495 & 3.070 & 353 & 363 & 7.281 \\
\hline 1791-1795 & 5.516 & 2.300 & 0 & 0 & 7.816 \\
\hline $1796-1800$ & 2.830 & 1.458 & 296 & 0 & 4.584 \\
\hline 1801-1805 & 4.523 & 2.103 & 882 & 530 & 8.038 \\
\hline 1806-1807 & 4.223 & 1.060 & 0 & 1.060 & 6.343 \\
\hline Subtotal & 37.899 & 22.209 & 1.531 & 2.732 & 64.371 \\
\hline Total & 41.696 & 30.300 & 1.531 & 4.684 & 78.211 \\
\hline
\end{tabular}

Fonte: The Trans-Atlantic Slave Trade Database. Disponível em www.slavevoyages.org. Filtros utilizados: Time frame > 1514 a 1807; Principal place of slave purchase > Bissau, Cacheu, Portuguese Guinea, Cape Verde Islands.

Importante também falar dos portos traficantes. A tabela mostra que não há uma viragem apenas no número de escravos traficados. Pode-se observar também que até o ano de 1756, Cacheu aparecia como a principal feitoria escravista na região dos Rios da Guiné, embarcando 58,4\% de todos os escravos remetidos entre 1701 e 1756. Já na segunda metade do século XVIII, tem-se que Bissau ganhou em importância e 
passou a exportar 58,8\% dos escravos no período compreendido entre 1756 e 1807. Para melhor visualização da importância dos portos traficantes, para todo o Setecentos e os sete primeiros anos do XIX, segue o gráfico abaixo:

\section{Gráfico IV. Participação dos Portos Traficantes (1701-1807)}

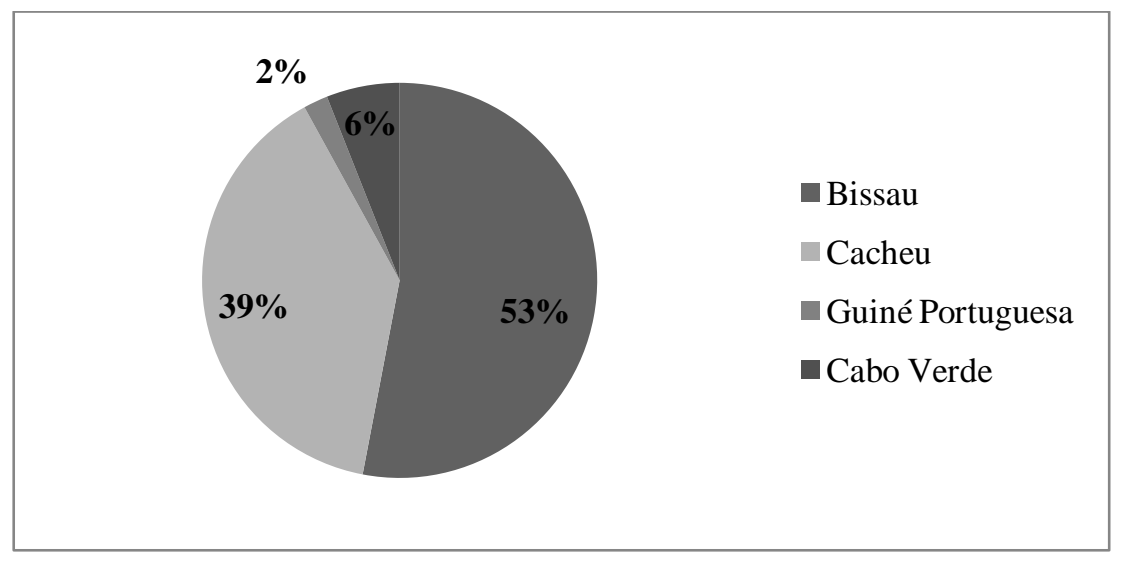

Como já apontado, Bissau liderou as exportações de escravos no período com 53\% das exportações, ou 41.696 peças como apontado pela Tabela (?); em seguida vem Cacheu com 39\% das remessas, ou 30.300 escravos; Cabo Verde e os outros portos da Guiné Portuguesa com 8\% dos escravos embarcados, ou 6.215 peças. Posto isso, outro fator importante e que merece ser analisado seria a flutuação dessas exportações, o que permitiria observar mais detalhadamente os altos e baixos do comércio de almas no decorrer do período. Sendo assim, o gráfico abaixo propiciará essa análise:

\section{Gráfico V. Flutuação dos Escravos Embarcados em África (1701-1807)}

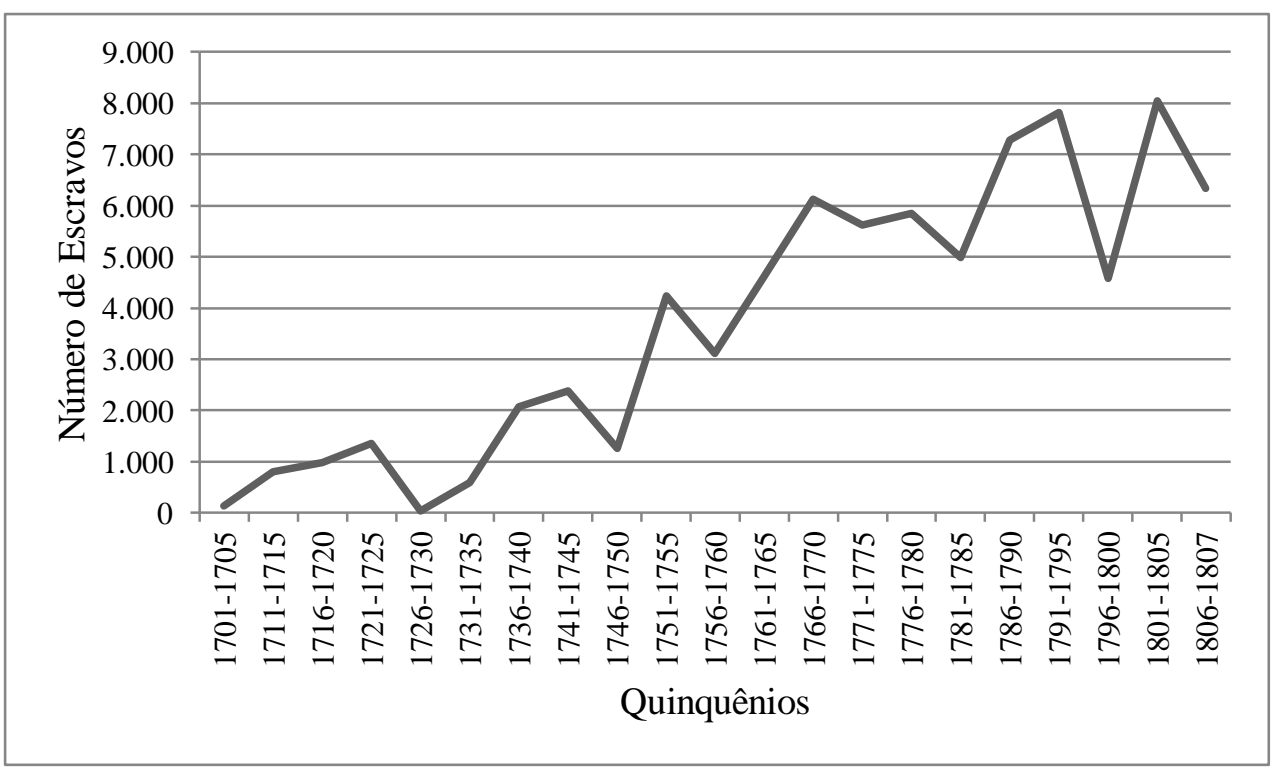


Entre as décadas de 1750 e 1770 o comércio de almas na região é notadamente crescente, encontrando justamente seu ápice em meados de 1770. A explicação está no fato da criação da Companhia de Comércio, em 1756. Corrobora a importância da empresa monopolista para a expansão da oferta de escravos para a América Portuguesa. A pequena retração do comércio de almas observado no início da década de 1780, após a extinção do monopólio, é devido - muito provavelmente - à tentativa de reorganização do negócio, que fora tocado de forma exclusiva pela Companhia até 1778. A quebra do exclusivo comercial, no entanto, foi benéfica, pois a partir de meados da década 1780, os embarques de escravos cresceram ainda mais, já que foi possível a entrada de embarcações de outros comerciantes.

No entanto, não se pode descartar a importância da Companhia. Foi instrumento importante da política econômica portuguesa. É inegável o impacto extremamente positivo da empresa monopolista para o tráfico de escravos nos Rios da Guiné. Mas não só. Além disso, o monopólio permitiu que Portugal conseguisse estabelecer sua presença na região, já que como dito, cerceando o contrabando estrangeiro a metrópole conseguia também defender suas feitorias. Outro fato fundamental a ser apresentado é que a maioria absoluta desses escravos, oriundos dos Rios da Guiné, teve como destino a América Portuguesa. A tabela XII abaixo ilustra a afirmação.

A tabela corrobora a afirmação da prevalência da América Portuguesa em receber esses escravos dos Rios da Guiné e Cabo Verde: nada menos, que 97,5\% da escravaria que chegou viva ao seu destino, no período entre 1701 e 1807, teve seu destino os portos coloniais portugueses. $\mathrm{O}$ aumento dos escravos desembarcados a partir de 1756 nas colônias lusitanas reforça a importância da Companhia, como ponto de partida para o aumento do comércio de almas na altura do Atlântico Equatorial.

Outro ponto importante, quando se compara a Tabela XI com a Tabela XII, é que no período após a criação da empresa pombalina é a redução ainda maior das taxas de mortalidade. Ao todo, dos 64.371 escravos embarcados nos Rios da Guiné, 61.420 chegaram aos seus portos de destino vivos: o que aponta para uma taxa de 4,5\%, menos da metade da média - que era por volta de $10 \%$ - no período para as outras rotas, como já foi mencionado anteriormente. Isso se deveu às melhorias nas condições de transporte propiciadas pela Companhia de Comércio, tendo em vista que a morte de parte dos 
escravos tomava parte considerável dos custos da empresa, e que refletia diretamente nos lucros do negócio.

Tabela XII. Escravos Desembarcados (1756-1807)

\begin{tabular}{|c|c|c|c|c|c|}
\hline Anos & Europa & $\begin{array}{c}\text { América } \\
\text { Norte }\end{array}$ & Caribe & $\begin{array}{c}\text { América } \\
\text { Portuguesa }\end{array}$ & Total \\
\hline 1701-1705 & 0 & 0 & 0 & 130 & 130 \\
\hline $1716-1701$ & 0 & 0 & 0 & 0 & $\mathbf{0}$ \\
\hline $1711-1715$ & 0 & 0 & 81 & 714 & 795 \\
\hline $1716-1720$ & 0 & 0 & 0 & 923 & 923 \\
\hline $1721-1725$ & 182 & 235 & 27 & 905 & 1.349 \\
\hline $1726-1730$ & 39 & 0 & 0 & 0 & 39 \\
\hline $1731-1735$ & 8 & 0 & 0 & 259 & 267 \\
\hline $1736-1740$ & 17 & 83 & 0 & 843 & 943 \\
\hline 1741-1745 & 467 & 0 & 331 & 908 & 1.706 \\
\hline $1746-1750$ & 0 & 0 & 107 & 812 & 919 \\
\hline $1751-1755$ & 362 & 0 & 663 & 1.626 & 2.651 \\
\hline Subtotal & 1.075 & 318 & 1.209 & 7.120 & 9.722 \\
\hline $1756-1760$ & 509 & 0 & 169 & 2.230 & 2.908 \\
\hline $1761-1765$ & 0 & 0 & 282 & 3.755 & 4.037 \\
\hline $1766-1770$ & 0 & 0 & 291 & 5.837 & 6.128 \\
\hline $1771-1775$ & 0 & 0 & 45 & 5.568 & 5.613 \\
\hline $1776-1780$ & 0 & 0 & 0 & 5.851 & 5.851 \\
\hline $1781-1785$ & 0 & 0 & 0 & 4.457 & 4.457 \\
\hline $1786-1790$ & 0 & 0 & 0 & 6.565 & 6.565 \\
\hline $1791-1795$ & 0 & 0 & 0 & 7.816 & 7.816 \\
\hline 1796-1800 & 0 & 0 & 0 & 4.584 & 4.584 \\
\hline 1801-1805 & 0 & 0 & 237 & 7.801 & 8.038 \\
\hline 1806-1807 & 0 & 0 & 0 & 5.423 & 5.423 \\
\hline Subtotal & 509 & 0 & 1.024 & 59.887 & 61.420 \\
\hline Total & 1.584 & 318 & 2.233 & 67.007 & 71.142 \\
\hline
\end{tabular}

Fonte: The Trans-Atlantic Slave Trade Database. Disponível em www.slavevoyages.org. Filtros utilizados: Time frame > 1514 a 1807; Principal place of slave purchase > Bissau, Cacheu, Portuguese Guinea, Cape Verde Islands.

Posto isso, foi observado que os escravos, originários dos Rios da Guiné, tiveram quase que exclusivamente como destino os portos coloniais da América 
Portuguesa. Os dados obtidos também revelam o destino dos 67.007 escravos que entraram na colônia portuguesa no Novo Mundo entre os anos de 1701 e 1807. A tabela abaixo ilustra tal fato:

Tabela XIII. Escravos Desembarcados divididos pelos portos coloniais portugueses (1701-1807)

\begin{tabular}{|c|c|c|c|c|c|c|}
\hline Anos & Amazônia & Bahia & Pernambuco & Sudeste & Outros & Total \\
\hline $1701-1705$ & 130 & 0 & 0 & 0 & 0 & 130 \\
\hline $1706-1710$ & 0 & 0 & 0 & 0 & 0 & $\mathbf{0}$ \\
\hline $1711-1715$ & 0 & 714 & 0 & 0 & 0 & 714 \\
\hline $1716-1720$ & 0 & 805 & 118 & 0 & 0 & 923 \\
\hline $1721-1725$ & 0 & 0 & 649 & 0 & 256 & 905 \\
\hline $1726-1730$ & 0 & 0 & 0 & 0 & 0 & $\mathbf{0}$ \\
\hline $1731-1735$ & 0 & 259 & 0 & 0 & 0 & 259 \\
\hline $1736-1740$ & 77 & 465 & 0 & 301 & 0 & 843 \\
\hline $1741-1745$ & 201 & 538 & 0 & 169 & 0 & 908 \\
\hline $1746-1750$ & 0 & 347 & 0 & 465 & 0 & 812 \\
\hline $1751-1755$ & 1.436 & 190 & 0 & 0 & 0 & 1.626 \\
\hline Subtotal & 1.844 & 3.318 & 767 & 935 & 256 & 7.120 \\
\hline $1756-1760$ & 2.230 & 0 & 0 & 0 & 0 & 2.230 \\
\hline $1761-1765$ & 3.755 & 0 & 0 & 0 & 0 & 3.755 \\
\hline $1766-1770$ & 5.837 & 0 & 0 & 0 & 0 & 5.837 \\
\hline $1771-1775$ & 5.568 & 0 & 0 & 0 & 0 & 5.568 \\
\hline $1776-1780$ & 5.498 & 0 & 353 & 0 & 0 & 5.851 \\
\hline $1781-1785$ & 4.457 & 0 & 0 & 0 & 0 & 4.457 \\
\hline $1786-1790$ & 6.540 & 0 & 25 & 0 & 0 & 6.565 \\
\hline $1791-1795$ & 7.592 & 0 & 224 & 0 & 0 & 7.816 \\
\hline $1796-1800$ & 4.519 & 0 & 65 & 0 & 0 & 4.584 \\
\hline $1801-1805$ & 7.801 & 0 & 0 & 0 & 0 & 7.801 \\
\hline 1806-1807 & 5.423 & 0 & 0 & 0 & 0 & 5.423 \\
\hline Subtotal & 59.220 & $\mathbf{0}$ & 667 & 0 & $\mathbf{0}$ & $\mathbf{5 9 . 8 8 7}$ \\
\hline Total & 61.064 & 3.318 & 1.434 & 935 & 256 & 67.007 \\
\hline
\end{tabular}

Fonte: The Trans-Atlantic Slave Trade Database. Disponível em www.slavevoyages.org. Filtros utilizados: Time frame > 1514 a 1807; Principal place of slave purchase > Bissau, Cacheu, Portuguese Guinea, Cape Verde Islands.

Temos que de toda a escravaria originária dos Rios da Guiné introduzida na América Portuguesa, 89,3\% foi movimentada após 1756. Os dados analisados mostram que a criação da Companhia marcou outra viragem. A tabela mostra que até o ano de 
1755, os escravos vindos de Bissau, Cacheu e Cabo Verde tinham a Bahia como prioridade recebendo $46,6 \%$ dos escravos remetidos. Com a criação da empresa pombalina, o fluxo da escravaria vinda da Guiné mudou para a Amazônia: 98,8\% dos africanos das feitorias portuguesas guineenses foram introduzidos no mercado amazônico entre 1756 e 1807. Os 61.064 escravos que desembarcaram na Amazônia entre 1701 e 1807, o fizeram por dois portos principais: São Luís, na capitania do Maranhão e Belém, na capitania do Grão-Pará. A tabela abaixo demonstra a quantidade de escravos introduzidos em cada um destes dois portos:

Tabela XIV. Escravos Introduzidos nos portos da Amazônia (1701-1807)

\begin{tabular}{|c|c|c|c|}
\hline Anos & Maranhão & Pará & Total \\
\hline $1701-1705$ & 130 & 0 & 130 \\
\hline $1706-1710$ & 0 & 0 & $\mathbf{0}$ \\
\hline $1711-1715$ & 0 & 0 & $\mathbf{0}$ \\
\hline 1716-1720 & 0 & 0 & $\mathbf{0}$ \\
\hline $1721-1725$ & 0 & 0 & $\mathbf{0}$ \\
\hline $1726-1730$ & 0 & 0 & 0 \\
\hline $1731-1735$ & 0 & 0 & $\mathbf{0}$ \\
\hline $1736-1740$ & 77 & 0 & 77 \\
\hline $1741-1745$ & 201 & 0 & 201 \\
\hline $1746-1750$ & 0 & 0 & $\mathbf{0}$ \\
\hline $1751-1755$ & 485 & 951 & 1.436 \\
\hline $1756-1760$ & 1.223 & 1.007 & 2.230 \\
\hline $1761-1765$ & 2.177 & 1.578 & 3.755 \\
\hline $1766-1770$ & 3.471 & 2.366 & 5.837 \\
\hline 1771-1775 & 1.872 & 3.696 & 5.568 \\
\hline $1776-1780$ & 3.038 & 2.460 & 5.498 \\
\hline 1781-1785 & 3.316 & 1.141 & 4.457 \\
\hline 1786-1790 & 5.480 & 1.060 & 6.540 \\
\hline $1791-1795$ & 6.575 & 1.017 & 7.592 \\
\hline 1796-1800 & 4.406 & 113 & 4.519 \\
\hline 1801-1805 & 6.210 & 1.591 & 7.801 \\
\hline 1806-1807 & 4.893 & 530 & 5.423 \\
\hline Total & 43.554 & 17.510 & 61.064 \\
\hline
\end{tabular}

Fonte: The Trans-Atlantic Slave Trade Database. Disponível em www.slavevoyages.org. Filtros utilizados: Time frame > 1514 a 1807; Principal place of slave purchase > Bissau, Cacheu, Portuguese Guinea, Cape Verde Islands. 
A tabela demonstra que o porto de São Luis recebeu mais escravos que o de Belém, em aproximadamente duas vezes e meia. São 71,3\% dos escravos vindos dos Rios da Guiné que desembarcaram no Maranhão, ou 43.554 peças; 28,7\% tiveram como destino o Grão-Pará, ou 17.510 peças: totalizando 61.064 escravos vindos de Bissau, Cacheu e Cabo Verde que tiveram como destino os portos amazônicos. Tal fato vai influenciar diretamente em como a economia amazônica se organizou no decorrer do século XVIII, sobretudo após a criação da Companhia de Comércio.

\subsection{Os têxteis de Cabo Verde e o Tráfico de Escravos nos Rios da Guiné (1758-} 1777)

No decorrer dos dois primeiros capítulos desse trabalho, foi reiterada diversas vezes a importância dos têxteis caboverdianos, para o negócio negreiro nas feitorias portuguesas da Guiné. Tem-se em mãos, nesse momento, os dados referentes às exportações dos tecidos do arquipélago para Bissau e Cacheu - entre os anos de 1758 e 1782 - apresentados no Capítulo I desta obra, bem como os dados referentes ao tráfico de escravos para todo o século XVIII, demonstrados e discutidos no presente capítulo. Assim sendo, pode-se avaliar a real importância da panaria produzida em Cabo Verde, para o comércio de escravos nos Rios da Guiné, tão comentada na documentação qualitativa, como pela pouca historiografia existente e que discute essa região.

Todos os dados, apresentados na Tabela XV, tem sua origem nos números da Companhia do Comércio do Grão-Pará e Maranhão. Apesar de conseguir discutir os números referentes aos têxteis até 1782 , optou-se por marco final o ano de 1777 , pois os dados que dizem respeito aos valores da escravaria nas feitorias portuguesas dos Rios da Guiné, só estavam disponíveis até o referido ano. Posto isso, a tabela abaixo mostra o valor dos têxteis nos Rios da Guiné - já que na Tabela VII, no primeiro capítulo já estão descritas as quantidades - a quantidade de escravos e seu valor em África, bem como a relação da porcentagem dos escravos que era paga com os tecidos remetidos: 
Tabela XV. Porcentagem dos Escravos que era paga com os Têxteis Caboverdianos (1759-1777)

\begin{tabular}{|c|c|c|c|c|}
\hline \multirow[t]{2}{*}{ Anos } & \multicolumn{2}{|c|}{ Escravos } & \multirow{2}{*}{$\begin{array}{l}\text { Têxteis } \\
\text { Valor }\end{array}$} & \multirow[t]{2}{*}{$\%$} \\
\hline & Quantidade & Valor & & \\
\hline 1758 & 758 & $55: 459 \$ 072$ & $5: 743 \$ 614$ & 10,36 \\
\hline 1759 & 517 & $35: 554 \$ 547$ & $3: 377 \$ 110$ & 9,50 \\
\hline 1760 & 701 & $49: 748 \$ 528$ & $11: 356 \$ 160$ & 22,83 \\
\hline 1761 & 930 & $66: 000 \$ 187$ & $8: 612 \$ 745$ & 13,05 \\
\hline 1762 & 2.682 & $190: 336 \$ 024$ & $9: 797 \$ 340$ & 5,15 \\
\hline 1763 & 735 & $52: 161 \$ 438$ & $7: 205 \$ 302$ & 13,81 \\
\hline 1764 & 1.737 & $123: 271 \$ 317$ & $8: 847 \$ 289$ & 7,18 \\
\hline 1765 & 1.802 & $127: 884 \$ 234$ & $9: 830 \$ 367$ & 7,69 \\
\hline 1766 & 1.049 & $74: 445 \$ 373$ & $20: 818 \$ 416$ & 27,96 \\
\hline 1767 & 1.518 & $107: 729 \$ 338$ & $14: 565 \$ 438$ & 13,52 \\
\hline 1768 & 1.324 & $93: 961 \$ 557$ & $23: 512 \$ 561$ & 25,02 \\
\hline 1769 & 812 & $57: 625 \$ 970$ & $28: 946 \$ 735$ & 50,23 \\
\hline 1770 & 1.250 & $88: 709 \$ 929$ & $30: 259 \$ 064$ & 34,11 \\
\hline 1771 & 1.078 & $76: 503 \$ 443$ & $14: 199 \$ 252$ & 18,56 \\
\hline 1772 & 1.243 & $88: 213 \$ 154$ & $34: 679 \$ 883$ & 39,31 \\
\hline 1773 & 1.016 & $72: 103 \$ 430$ & $18: 591 \$ 606$ & 25,78 \\
\hline 1774 & 975 & $69: 193 \$ 745$ & $11: 105 \$ 987$ & 16,05 \\
\hline 1775 & 1.256 & $89: 135 \$ 737$ & $43: 352 \$ 722$ & 48,64 \\
\hline 1776 & 2.207 & $156: 626 \$ 251$ & $31: 739 \$ 564$ & 20,26 \\
\hline 1777 & 1.215 & $86: 226 \$ 051$ & $13: 927 \$ 876$ & 16,15 \\
\hline Total & 24.805 & $1.760: 889 \$ 325$ & $350: 469 \$ 031$ & 19,90 \\
\hline
\end{tabular}

Fontes: Para os dados referentes aos escravos, foi utilizado Mapa do Comércio da Companhia do Grão-Pará e Maranhão, encontrado no Arquivo Histórico Ultramarino, Avulsos de Cabo Verde, Caixa 37, documento 48-B; o número de escravos foi cruzado com a base de dados montada através do Data Base. Já referente aos têxteis, os dados foram extraídos de: CARREIRA. Op.cit. 1988, (p.251-2). Ver Tabela VII.

A tabela aponta para várias coisas interessantes. A primeira delas é que a Companhia comprou 24.805 escravos nas feitorias de Bissau e Cacheu, entre os anos de 1758 e 1777 , que custaram um montante de $1.760 .889 \$ 325$ contos de réis: o que daria o 
valor médio de quase 71\$000 réis, por cada peça. A segunda delas, e mais importante do ponto de vista desse trabalho, é a variação na porcentagem que as remessas de têxteis de Cabo Verde pagariam do valor de compra dos escravos: variou de um mínimo de 5,1\% no ano de 1962, para um máximo de 50,2\% no ano de 1769 . No conjunto, tem-se que a panaria caboverdiana custeou quase $20 \%$ da escravaria adquirida no período, o que se não chega a ser muito significante, também não pode ser considerada desprezível.

Nesse sentido, como parâmetro comparativo com outros ramos do tráfico português, em relação aos produtos utilizados e que garantiam vantagem nas feitorias africanas, temos que em Angola a jeribita - produzida no Brasil - é tida pela historiografia como produto fundamental para o negócio; enquanto isso, na Costa da Mina, era o tabaco produzido no Nordeste. As estimativas mais generosas sugerem que entre $27 \%$ e $40,5 \%$ dos escravos remetidos de Angola, foram custeados pela aguardente. ${ }^{132}$ Contudo, estudos mais recentes têm procurado revisar essas estimativas, apontando para a proporção de $10 \%$ a $30 \%$ dos custos da escravaria oriunda de Luanda; ressaltam ainda, que na longa duração a média estava bem mais próxima dos $10 \%{ }^{133}$

Outros estudos apontam para uma estimativa de $48 \%$ dos custos dos escravos vindos da África, eram pagos pelas remessas de cachaça e de tabaco. ${ }^{134}$ Contudo, o mesmo estudo que revisou os números da jeribita para Angola, sugere que especialmente as remessas de tabaco, custearam cerca de $50 \%$ a $75 \%$ do valor dos escravos vindos da Costa da Mina. E a explicação para tal diferença nas estimativas de Angola e Costa da Mina, se deu pelas particularidades de cada uma das feitorias de tráfico: enquanto que em Angola, o exclusivo comercial exercido por Portugal, "afastava a concorrência de outras nações e garantia à economia metropolitana uma fração do comércio de importações" ${ }^{135}$; na Costa da Mina a concorrência com as outras metrópoles, diminuía a demanda por manufaturados europeus; no entanto, "o tabaco brasileiro não possuía rival, o que seguramente explica a importância do fumo na compra de escravos"

\footnotetext{
${ }^{132}$ Curto, José. Álcool e Escravos. Lisboa, Editora Vulgata, 2002. (p.352) Apud ACIOLI \& MENZ. Resgate e mercadorias. Op.cit.

${ }^{133}$ ACIOLI \& MENZ. Resgate e mercadorias. Op.cit. (p.20)

${ }^{134}$ ALENCASTRO. Op. Cit. (p.324)

${ }^{135}$ ACIOLI \& MENZ. Resgate e mercadorias. Op.cit. (p.21)

${ }^{136}$ ACIOLI \& MENZ. Resgate e mercadorias. Op.cit. (p.21)
} 
Nesse sentido, percebe-se que a maneira como o negócio se organizava nos Rios da Guiné, estava mais próximo do modelo angolano, do que o da Costa da Mina. Isso porque, nas feitorias de Bissau e Cacheu não havia concorrência de outras metrópoles, fruto da criação da Companhia de Comércio. Quando se observa as remessas da Companhia para as feitorias, e também do pequeno período entre 1796 e 1799, em que se têm os dados para a região nas Balanças de Comércio, percebe-se uma variedade de produtos metropolitanos como bebidas alcoólicas, pólvora, armamentos, ferramentas. Mesmo que os tecidos sejam superestimados pela historiografia, não se pode descartá-los totalmente: assim como a jeribita em Angola, muito provavelmente estes tecidos traziam uma vantagem ao comerciante que os possuía, tendo em vista que existe uma demanda considerável no que diz respeito às quantidades.

Afinal se em 1806 existiam na praça de Bissau, que era a principal feitoria de tráfico nos Rios da Guiné, 168 habitações de súditos portugueses e aproximadamente 638 habitantes, contando a escravaria, decerto as 5.250 peças/ano enviadas pela Companhia e as 2.000 peças/ano que Marcelino António Bastos referiu em seu plano econômico de 1798 eram destinadas ao tráfico de escravos: não havia tantos colonos e soldados assim para vestir em Bissau e Cacheu. Os panos bastante apreciados, não somente no entorno das feitorias, mas também nas feiras que margeavam os principais rios da região, além de custear 1/5 do valor dos escravos, muito provavelmente serviam como um diferencial no momento de fazer negócios. ${ }^{137}$

O tráfico de escravos nos Rios da Guiné era um negócio bastante complexo. Envolvia uma série de especificidades, que iam muito além da Companhia e dos panos caboverdianos para se realizar. De fato tanto uma, quanto outros são elementos importantes para entender o porquê Portugal conseguiu se estabelecer e possuir certo controle nas feitorias de Bissau e Cacheu. É importante lembrar, que grande parte dos escravos embarcados nas feitorias, tinha como origem as feiras do sertão como as mencionadas Geba e Zeguinchor: a empresa monopolista precisava muito mais do que os poucos agentes e um administrador estabelecidos em Cacheu, e dos capitães das embarcações para fazer o negócio por conta própria em Bissau.

137 Sobre a população, extraído de: Arquivo Histórico Ultramarino, Avulsos da Guiné, Caixa 18, documento 65. Mapa Demográfico de Bissau, de 21 de maio de 1806. 
O ponto para entender como Portugal foi conseguindo exercer, pouco a pouco, o controle do tráfico de escravos na região é uma amálgama de três elementos: a Companhia de Comércio, que com o monopólio acabava por limitar a atuação de comerciantes estrangeiros na região; a existência de Cabo Verde como colônia/entreposto comercial português, o que garantia uma localização estratégica no Atlântico, e também acesso - quase que exclusivo - dos têxteis manufaturados nas ilhas, que apesar de superestimados, eram demandados e necessários para realizar o negócio em África; por fim, mas não menos importante, a maneira como se estruturou a sociedade dos Rios da Guiné, através da crioulização.

O termo crioulo referia-se a assimilação dos valores portugueses e africanos, por parte dos naturais de Cabo Verde e Rios da Guine, como pressuposto fundamental de sua identidade. O termo tem sido usado para se referir as transformações culturais e identitárias dos agentes envolvidos pelo tráfico: escravos, escravocratas e trabalhadores do comércio de escravos. Tais indivíduos possuíam traços da cultura européia, africana e americana, contudo não faziam parte de nenhum destes três universos. Eram "familiarizados com o comércio atlântico, fluentes com suas novas linguagens, e íntimos com suas culturas e finanças."

A quantidade de afro-portugueses atuando diretamente ou como intermediários, nos negócios dos Rios da Guiné, era tão grande que chegaram a controlar praticamente todo o comércio. Esses comerciantes de grosso trato na região, muitas vezes possuíam um poderoso circuito comercial estabelecido com alguns povos que habitavam a costa, mas principalmente no sertão, como o Papel e o Banhun, "and probably others among whom shed welt and traded, because of the identity of interest on the question of free trade. This applied to thew hole Afro-Portuguese group." $" 139$ Importante dizer que alguns desses mestiços também eram encarregados de alguns cargos da administração portuguesa, como Francisco Rabelo que foi alferes da ordenança, por exemplo. ${ }^{140}$

\footnotetext{
${ }^{138}$ FERREIRA, Roquinaldo. "Ilhas Crioulas": o Significado Plural da Mestiçagem Cultural na África Atlântica. Revista de História 155 (2 - 2006), 17-41. (p.21).

${ }^{139}$ RODNEY, Walter. Op. Cit. (p.208-9 e 212)

${ }^{140}$ Arquivo Histórico Ultramarino, Avulsos de Cabo Verde, Caixa 34, documento 25. Carta do governador Saldanha Lobo, de 15 de março de 1775.
} 
Essas camadas da população local, que formava o grupo de comerciantes, que controlavam boa parte das relações mercantis, combinavam muitos elementos da cultura portuguesa em seu estilo de vida: roupas oriundas da metrópole, no uso do crucifixo apesar de não assumir totalmente o catolicismo como religião - e a adoção de nomes portugueses. Nesse sentido, esse movimento de aculturação que ocorreu em um processo de longa duração, pode ter aproximado esses comerciantes mestiços dos poucos portugueses que se estabeleciam nas praças de Bissau e Cacheu, ou que estavam apenas de passagem para negociar escravos. Sendo assim, temos o terceiro fator que proporcionava o acesso (quase que) exclusivo dos portugueses ao mercado dos Rios da Guiné, na segunda metade do século XVIII.

Quando se parte para a análise de todos os dados apresentados neste capítulo, ratifica-se que a Companhia - além de ser um fator, que garantia o acesso lusitano ao mercado de escravos guineense - agiu de maneira positiva para o tráfico de escravos nos Rios da Guiné, assim como proporcionou a introdução de mão de obra africana na Amazônia. Observou-se também que Bissau, no decorrer do século XVIII se tornou o principal entreposto do tráfico, responsável em abastecer os portos de Belém e de São Luís. O tráfico de escravos estabeleceu-se de vez na região dos Rios da Guiné, centralizando os fluxos de oferta para a colonização da região amazônica, em especial ao Estado do Grão-Pará e Maranhão. Analisando os números para o trato negreiro antes, durante e depois do funcionamento da empresa monopolista, o que se vê em um primeiro momento é um aumento substancial do número de africanos introduzidos no norte da colônia com o advento da companhia pombalina; após o seu fím a tendência foi de um crescimento gradual até pelo menos 1807.

Assim sendo, apesar das constantes reclamações dos mercadores locais, reclamando dos efeitos negativos ocasionados pelo estanco comercial e pela falta de liberdade de comerciar, acabou possibilitando um círculo virtuoso entre o comércio de escravos e a produção agrícola e pecuária na Amazônia. A Companhia teve, durante os anos de sua atividade, 42 embarcações. E dessas, 27 se ocupavam da navegação de longa distância, ou seja, imbuída no tráfico negreiro entre os Rios da Guiné e Amazônia. ${ }^{141}$ Assim, os impactos do tráfico de escravos na economia amazônica serão visto no próximo capítulo.

${ }^{141}$ CARREIRA. Op. Cit. 1988. (p.45) 


\section{CAPÍTULO III - A ECONOMIA AMAZÔNICA NA LONGA DURAÇÃO (c.1680 - 1807)}

A ocupação e colonização do espaço amazônico, pela Monarquia Ibérica, se deram após os esforços de expulsão dos franceses de São Luís em 1615, partindo de colonos originários da capitania de Pernambuco fundamentalmente. Nesse mesmo ano, alguns meses depois da tomada do que viria a ser a capital da capitania do Maranhão, Francisco Caldeira fundava na margem direita da foz do rio Amazonas a cidade de Santa Maria de Belém do Pará. Tal fato foi a pedra fundamental para o controle, por parte de Portugal, de uma zona estratégica e cobiçada por ingleses, franceses e holandeses: a bacia hidrográfica do Amazonas.

E por que era importante controlar uma região pouco ocupada por colonos, sem uma produção agropastoril minimamente desenvolvida e que resultava em uma economia extremamente frágil?Durante a primeira metade do século XVII, a Dinastia Filipina tinha a pretensão de unir o litoral da América Portuguesa ao da América Espanhola. Sua intenção, a partir da fundação de Belém do Pará em 1615, era de unir o único trecho de litoral que ainda faltava ocupar: aquele que se encontrava entre as fozes do rio Orenoco e do Amazonas. Contudo, as outras metrópoles européias já haviam começado um processo de ocupação da região, que daria origem as Guianas. Logo, controlar o principal ponto de entrada rumo ao interior do continente era uma maneira eficaz de evitar que ingleses, holandeses e franceses acessassem o interior do continente, bem como evitar o uso do caminho alternativo para as minas castelhanas nos Andes. $^{142}$

Ainda sob a égide de Madrid, diversas expedições foram organizadas no decorrer da década de 1630, com o intuito de alargar as fronteiras do Império, consolidar o domínio sobre o território e buscar novas vias de comunicação entre os Andes e o Atlântico. E mesmo com a Restauração Portuguesa em 1640, a foz do Amazonas continuava a ser estratégica para Lisboa, pois era o principal via de entrada

\footnotetext{
${ }^{142}$ Ressalta-se que em 1540, uma expedição encabeçada por Gonzalo Pizarro e Francisco Orellana, saiu de Quito e chegou ao Oceano Atlântico no ano seguinte, via bacia amazônica. Orellana seria o primeiro homem a percorrer todo o rio Amazonas - desde os Andes, até sua foz - criando uma via de comunicação alternativa entre as minas de prata de Castela no altiplano andino, e o Atlântico. Cf: PORRO, Antônio. As crônicas do Rio Amazonas. Petrópolis: Vozes, 1992.
} 
em território amazônico e o acesso ao "rico" interior do continente. ${ }^{143}$ E mesmo com todas as dificuldades impostas pela jornada rio acima, "o Amazonas passou a ser para o Estado do Maranhão, uma via real de expansão europeia, cuja exploração econômica se efetuou ao ritmo do avanço humano para o coração do continente sul-americano"144.

No decorrer deste capítulo, buscaremos apreender como se deu essa exploração econômica do espaço amazônico no período entre 1680 e 1807, que só se consolidara pelo controle lusitano da principal via de acesso ao interior de seu território. Contudo, deteremos nossa análise principalmente no período entre 1756 e 1807, quando se consolidou uma rota de tráfico regular de escravos africanos - que é o fio condutor desse trabalho - para os dois principais portos da região, através da instituição da Companhia Geral do Comércio do Grão-Pará e Maranhão.

\subsection{A Economia no Estado do Grão-Pará e Maranhão (c.1680 - 1755)}

Em ofício datado de 24 de setembro de 1616, do capitão-mor do Maranhão, Alexandre de Moura já demonstrava como se configuraria a ocupação e a organização social e da produção na Amazônia até meados do século XVIII. Moura relatava ao rei Filipe II que havia muito poucos colonos portugueses, com alguns escravos indígenas denominados tapuyas, responsáveis pela pequena produção de subsistência. Dizia Moura ainda da necessidade imediata do envio de colonos vindo de Pernambuco, Itamaracá e Paraíba para ocupação da terra, bem como de provimentos, dada a baixa produtividade das pequenas lavouras locais. ${ }^{145}$

\footnotetext{
${ }^{143}$ A idéia da riqueza, do interior do continente americano, extrapola a questão da diversidade de produtos que poderiam ser ofertados pela exploração dos "sertões" amazônicos. Além da possibilidade de acesso aos metais preciosos oriundos da região andina, nos papéis avulsos do Maranhão e do Pará existe uma quantidade razoável de correspondências sobre expedições - particulares ou não - sobre a procura de ouro, como por exemplo, uma carta remetida em 22 de fevereiro de 1644, pelo do provedor da Fazenda Real no Maranhão, Inácio do Rego Barreto ao rei D. João IV, em que informava sobre a existência de minas de metais preciosos nos sertões do rio Amazonas, em que também se oferecia para montar uma expedição para i-las descobrir. Cf: Arquivo Histórico Ultramarino: Avulsos do Maranhão, Cx. 02, Doc. 144.

${ }^{144}$ SERRÃO, Joel \& OLIVEIRA MARQUES, A. H. Nova História da Expansão Portuguesa: o Império Luso-Brasileiro. Estampa: Lisboa, 1991. Vol. 2. (p.123).

${ }^{145}$ Arquivo Histórico Ultramarino. Avulsos do Maranhão, Caixa 01, documento 08. Ofício do capitão-mor do Maranhão Alexandre de Moura, de 24 de setembro de 1616.
} 
Além disso, as décadas finais do Seiscentos e a primeira metade do Setecentos foram marcados pelo intenso conflito entre colonos e jesuítas, pelo controle da mão de obra indígena. Conflito esse fruto de uma legislação indígena colonial bastante volátil, pois ora proibia terminantemente o cativeiro indígena, ora o permitia. Em 1680, o alvará promulgado pelo príncipe regente, D. Pedro, no dia primeiro de abril, abolia todo e qualquer tipo de cativeiro indígena e dava aos padres jesuítas a responsabilidade sobre o gentio. De acordo com Márcia Eliane Alves de Souza e Melo, afora o Alvará de primeiro de abril de 1680, algumas Ordens Régias foram encaminhadas para o Estado do Grão-Pará e Maranhão e destacavam

[...] que o governo das aldeias de índios fosse exercido somente pelos párocos e chefes indígenas e não mais por um capitão ou administrador; e que aos jesuítas fossem entregues as aldeias do Rio Amazonas que se encontrassem sem pároco e que eles fossem exclusivos missionários para novas missões a serem feitas nos sertões. ${ }^{146}$

Houve forte reação dos moradores, que reclamavam a impossibilidade de resgatar ou utilizar índios cativos em suas lavouras ou na colheita das drogas do sertão. Some-se ao fato, o insucesso da Companhia do Estanco do Maranhão, fundada em 1682, em introduzir escravos africanos na Amazônia em quantidade suficiente e preços razoáveis, no intento de substituir a mão de obra indígena pela africana. $O$ descontentamento dos colonos com a falta de mão de obra, com a atuação da Companhia acabou resultando no levante popular conhecido como Revolta de Beckman em 1684. Estes estavam insatisfeitos com a desvalorização dos poucos gêneros produzidos, pelos altos preços cobrados pelos produtos europeus e pela ínfima introdução de africanos a custos elevados. ${ }^{147}$

Pode-se dizer então, que esses episódios foram os precursores do Regimento das Missões do Estado do Maranhão e do Grão-Pará, que se não liberava o uso do indígena como cativo, permitia que eles servissem em defesa do Estado e a trabalharem

\footnotetext{
${ }^{146}$ MELO, Márcia Eliane Alves de Souza e. O Regimento das Missões: Poder e Negociação na Amazônia Portuguesa. In: Clio - Série Revista de Pesquisa Histórica - N. 27-1, 2009. (p. 49).

${ }^{147}$ CHAMBOULEYRON, Rafael. Duplicados clamores: Queixas e Rebeliões na Amazônia Colonial (século XVII). Projeto História, São Paulo, n.33, p. 159-178, dez.2006. (p. 164-5).
} 
para os particulares; no entanto, como eram considerados livres, deveriam ser pagos pelo trabalho prestado. ${ }^{148}$ Contudo, os colonos continuavam a solicitar a liberdade para resgatar e cativar os indígenas. Tentavam de toda forma dissuadir D. Pedro II, como em uma carta enviada ao Reino pelos oficiais da Câmara da cidade de Belém do Pará em 15 de novembro de 1685, em que diziam ir ao Maranhão, para levar adiante a idéia de se organizar um contrato de repartição de índios, já que a falta de escravos poderia fragilizar ainda mais, a já frágil economia amazônica. ${ }^{149}$ De certa forma, isso acabou pressionando a Coroa, que em 1688 enviou Alvará que autorizava o cativeiro indígena, desde que o índio fosse prisioneiro de outros índios. ${ }^{150}$

Tal medida foi sendo reforçada pela Carta Régia de nove de janeiro de 1697 em que se mandava oprimir os indígenas rebeldes e transformá-los em cativos; pela Carta Régia de 20 de novembro de 1699 em que ordenava aumentar o número de escravos para substituir àqueles índios aldeados que haviam sido mortos; e por fim, na Carta Régia de 10 de abril de 1709 em que "se proverão as aldeias de maior número de índios, [...] terão estes moradores quem os sirva, e se aumentarão os defensores desse Estado, assim para acudirem as ocasiões em que se oferecem dos inimigos." ${ }^{151}$ Ao fim e ao cabo, o problema do cativeiro e mão de obra indígena na Amazônia, vai perpassar toda a primeira metade do século XVIII, refletindo a estrutura social do período em que o português procurava se impor através dos elementos de coerção física - no caso dos colonos - ou simbólicos - no caso dos religiosos.

Contudo, percebemos que mesmo relaxando a legislação contra o cativeiro indígena, não foi estimulada uma produção agropastoril que saltasse aos olhos. A introdução de escravos africanos também não era regular no período compreendido entre 1680 e 1755, o que ajuda a explicar a baixa produtividade. A tabela XVI a seguir,

\footnotetext{
${ }^{148}$ MELO, Márcia Eliane Alves de Souza e. Op. Cit. (p.50).

${ }^{149}$ Arquivo Histórico Ultramarino; Avulsos do Pará, Caixa 03, documento 252.Carta de 15 de novembro de 1685, dos oficiais da câmara de Belém ao Reino, dando conta do problema do cativeiro indígena e da falta de mão de obra na região.

${ }^{150}$ Arquivo Histórico Ultramarino; Avulsos do Maranhão, Caixa 07, documento 796. Alvará de 28 de abril de 1688, do rei D. Pedro II sobre o resgate dos índios.

${ }^{151}$ Carta Régia de 09 de janeiro de 1697, disponível digitalizada em https://www.dropbox.com/s/txwz7qkklpy12sd/1697-01-08-09.pdf, acesso em 12/11/2014; Carta Régia de 20 de novembro de 1699, disponível digitalizada em https://www.dropbox.com/s/42zthurp3x8yg2d/169911-20.jpg, acesso em 12/11/2014; Carta Régia de 10 de abril de 1709, disponível digitalizada em https://www.dropbox.com/s/txwz7qkklpy12sd/1709-04-10.pdf, acesso em 12/11/2014.
} 
ilustra quantitativamente os escravos africanos que foram introduzidos na região amazônica, no período supracitado: ${ }^{152}$

Tabela XVI. Escravos Introduzidos na Amazônia (1680 - 1755)

\begin{tabular}{|c|c|c|c|c|}
\hline \multirow{2}{*}{ Anos } & \multirow{2}{*}{ Porto de Origem } & \multicolumn{3}{|c|}{ Escravos Introduzidos } \\
\cline { 3 - 5 } & & Maranhão & Pará & Soma \\
\hline 1693 & Cacheu & 140 & 0 & 140 \\
\hline 1695 & Cacheu & 102 & 0 & 102 \\
\hline 1696 & Cabo Verde & 158 & 0 & 158 \\
\hline 1701 & Cacheu & 115 & 0 & 115 \\
\hline 1703 & Costa da Mina & 170 & 0 & 170 \\
\hline 1708 & Costa da Mina & 87 & 0 & 87 \\
\hline 1715 & Costa da Mina & 85 & 0 & 85 \\
\hline 1740 & Cacheu & 77 & 0 & 69 \\
\hline 1741 & Cacheu & 7 & 0 & 7 \\
\hline 1743 & Cacheu & 92 & 0 & 92 \\
\hline 1752 & Senegâmbia & 0 & 150 & 150 \\
\hline 1752 & Bissau & 282 & 0 & 282 \\
\hline 1753 & Senegâmbia & 0 & 277 & 277 \\
\hline 1753 & Bissau & 0 & 150 & 150 \\
\hline 1755 & Bissau & 150 & 284 & 434 \\
\hline & TOTAL & $\mathbf{1 . 4 6 5}$ & $\mathbf{8 6 1}$ & $\mathbf{2 . 3 1 8}$ \\
\hline & & & & \\
\hline
\end{tabular}

Fonte: The Trans-Atlantic Slave Trade Database. Disponível em http://www.slavevoyages.org/, acesso em 10/07/2012. Filtros utilizados: Time Frame > 1680 - 1755; Principal place of slave landing > Brazil > Amazonia > Maranhão > Pará.

Como se pode observar, ao todo, na Amazônia foram introduzidos 2.318 africanos, pouco mais de 30 peças ao ano em média. Em números absolutos, há uma diferença significativa entre os escravos introduzidos no Maranhão e no Pará. Divididos

\footnotetext{
${ }^{152}$ Fonte: The Trans-Atlantic Slave Trade Database. Disponível em http://www.slavevoyages.org/, acesso em 10/07/2012. Filtros utilizados: Time Frame > $1680-1755$; Principal place of slave landing > Brazil > Amazonia > Maranhão > Pará.
} 
percentualmente, temos que entre os dois principais portos amazônicos $63 \%$ da escravatura desembarcou no porto de São Luís do Maranhão, e 37\% no porto de Belém. Já no que diz respeito aos portos de origem, temos a maioria absoluta dos escravos eram oriundos do complexo formado pelos Rios de Guiné (Bissau, Cacheu e Senegâmbia) e pelo arquipélago de Cabo Verde, representando $85 \%$ dos escravos importados pela Amazônia; os outros 15\% eram originários da Costa da Mina. Outro fator a se destacar, é que até 1740 não houve importação de escravaria no Grão-Pará, o que vai refletir diretamente em como se organizou a economia paraense, como será discutido a seguir.

Não possuímos uma série quantitativa para analisar a produção amazônica seja cultivada, seja coletada - entre os anos de 1680 e 1730. Mas podemos afirmar, de acordo com a correspondência disponível nos papéis avulsos do Maranhão e do Pará, que o principal produto da economia maranhense era o tabaco e algodão, que já vinham sendo cultivados precariamente desde meados do século XVII; ${ }^{153}$ e da paraense seriam o cacau e algumas drogas do sertão, principalmente o cravo que começaram a ser extraídos em maior quantidade no quartel final do mesmo século. ${ }^{154}$ Tentou-se implementar, sem sucesso, alguns engenhos de açúcar. Mas o imbróglio envolvendo o uso do indígena como cativo e a irrelevante importação de escravos africanos impediram o desenvolvimento de uma produção açucareira aos moldes do Estado do Brasil. Nesse sentido, temos que a economia amazônica de exportação, passou a virada do século XVII para o XVIII em estado de pouco desenvolvimento.

A partir de 1730, conseguimos coletar os dados de exportação para a capitania do Grão-Pará, e a arrecadação dos dízimos da terra para a do Maranhão. Com isso, é possível caracterizar o tamanho e como se comportou a flutuação da economia de exportação amazônica no período entre 1730 e 1755. Para o Grão-Pará temos para esse recorte temporal o seguinte panorama, descrito pelo gráfico abaixo: ${ }^{155}$

\footnotetext{
153 A primeira menção à produção de tabaco aparece em requerimento de 16 de setembro de 1637 dos moradores do Maranhão ao rei Filipe III, sobre a produção do tabaco. Arquivo Histórico Ultramarino; Avulsos do Maranhão, Caixa 01, documento 115. Já sobre a produção de algodão, aparece em carta dos oficiais da câmara da cidade de São Luís do Maranhão ao rei D. Afonso VI, de 04 de agosto de 1661. Arquivo Histórico Ultramarino; Avulsos do Maranhão, Caixa 04, documento 237.

${ }^{154}$ A primeira menção ao cacau e às drogas do sertão aparece em uma consulta do Conselho Ultramarino à D. Pedro, de 22 de dezembro de 1679, sobre organizar um sistema de cobrança de impostos do cravo e cacau na capitania do Pará. Arquivo Histórico Ultramarino. Avulsos do Pará, Caixa 01, documento 181.

${ }^{155}$ Arquivo Histórico Ultramarino; Avulsos do Pará, Caixa 80, documento. 6627. Ofício de 31 de agosto de 1778, do governador do Estado do Grão-Pará e Rio Negro, para o secretário de Estado da Marinha e Ultramar, Martinho de Melo e Castro. Para o gráfico, utilizamos nossa base de dados montada através de
} 
Gráfico VI. Exportações do Grão-Pará, 1730-1755 (em réis)

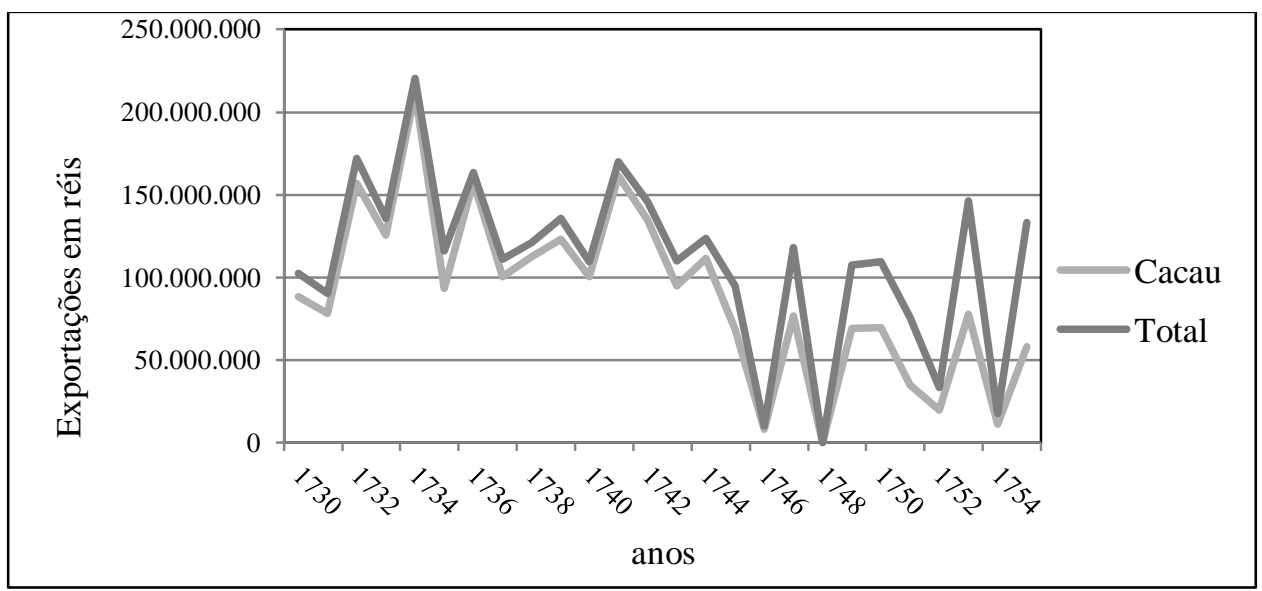

O gráfico demonstra a relevância do cacau, como principal produto de exportação da capitania do Grão-Pará no período entre 1730 e 1755. Observa-se que a tendência dos valores totais das exportações propende-se a acompanhar as remessas de cacau para a metrópole. O restante da composição, que integram as exportações paraenses do período, consiste basicamente em remessas pequenas de drogas do sertão salsa parrilha e cravo, fundamentalmente - e de uma ínfima quantidade de açúcar. A análise do gráfico também demonstra uma economia marcada por muita oscilação, com tendência a retração das exportações no âmbito da longa duração.

Além disso, remessas compostas basicamente pelo cacau e pelas drogas do sertão - produtos de origem extrativista - expõe como se organizou o sistema produtivo amazônico, pelos menos até 1755. A utilização do indígena era tida como fundamental, pois o a atividade extrativista "exigia penetração pela floresta e o seu profundo conhecimento, [...] [e] só o índio poderia suprir tais requisitos." ${ }^{156}$ Não é a toa todo o problema e disputa, envolvendo o controle e a utilização do trabalho indígena, que colocava frente a frente os interesses de colonos e clérigos: quem controlasse a única fonte de mão de obra, controlava ao mesmo tempo a principal fonte de riqueza da região amazônica.

vários documentos tabulados nos documentos avulsos do Pará e do Maranhão. Para consultar a documentação, ver Anexos. Agradeço a colega Michelle Carolina Brito, por ter cedido gentilmente os dados referente às exportações paraenses entre 1730 e 1808. Agradeço também ao Prof. Dr. Maximiliano Mac Menz pela grande ajuda na hora de construir a base de dados, com as exportações amazônicas.

${ }^{156}$ SOUZA, James O. A Mão de Obra Indígena na Amazônia Colonial. In: Em Tempos de Histórias. $\mathrm{n}^{\circ}$ 06, 2002. (p.01) 
Pelo menos até metade do século XVIII, os indígenas eram peças chaves para a colonização portuguesa na Amazônia. A partir da década de 1720 aumentou consideravelmente o número de solicitações para o descimento privado de indígenas. A partir de 1728 intensificaram-se ainda mais os descimentos, tendo em vista uma epidemia de varíola que dizimou boa parte dos índios aldeados. Nesse sentido,

Percebe-se que essa atividade se revestiu quase que em uma forma velada de se realizar resgates, utilizando-se dessa mão-de-obra como se ela fosse escrava, com a diferença de que esses índios não seriam passados aos descendentes dos moradores. Posteriormente a esse período, o número de alvarás reduziu consideravelmente. [...] as autorizações de descimentos somente deixaram de ser outorgadas no ano de $1747 .^{157}$

Tal fato demonstra que apesar dos clérigos possuírem o poder jurisdicional sobre o gentio, os colonos se apropriavam das determinações régias e das brechas na legislação para conseguir arregimentar mão de obra. A falta de acesso a mão de obra escrava, oriunda do mercado africano, tornou o indígena foco de uma disputa interminável. A questão da mão de obra indígena era o cerne das relações sociais na Amazônia Portuguesa, permeando não só os conflitos entre a comunidade secular e a religiosa, como desses dois setores da sociedade colonial com as próprias populações nativas. Ao mesmo tempo, essas relações determinavam o desenrolar de uma economia que era estruturalmente diferente do que havia no Estado do Brasil, que era baseada na mão de obra escrava, na produção agrícola monocultora em grandes porções de terra.

Quando se compara os dízimos da terra maranhenses, fica mais evidente o atraso da economia amazônica, em relação às outras capitanias do Estado do Brasil. A contratação dos dízimos foi um elemento do sistema fiscal utilizado pelo Império Português. Consistia em um contratador que arrematava o direito de cobrança do pagamento dos dízimos pelos produtores, sendo que o valor era estimado pelo conjunto da produção agropecuária da capitania; a partir daí detinha os direitos de cobrança sobre os impostos da produção colonial voltados para a exportação. O dízimo foi um dos

\footnotetext{
${ }^{157}$ CHAMBOULEYRON, Rafael \& BOMBARDI, Fernanda Aires. Descimentos privados de índios na Amazônia colonial (séculos XVII e XVIII). In: Varia História. Volume 27, $\mathrm{n}^{\circ} 46$ Belo Horizonte, Julho/Dezembro, 2011. (p.06)
} 
sustentáculos fundamentais do sistema fiscal português na colônia, que só perdeu um pouco em importância com o advento da mineração e os impostos alfandegários, que se tornaram os principais meios de arrecadação da Coroa. ${ }^{158}$ Posto isso, observemos o gráfico abaixo:

Gráfico VII. Dízimos da Terra, 1724-1755 (em réis)

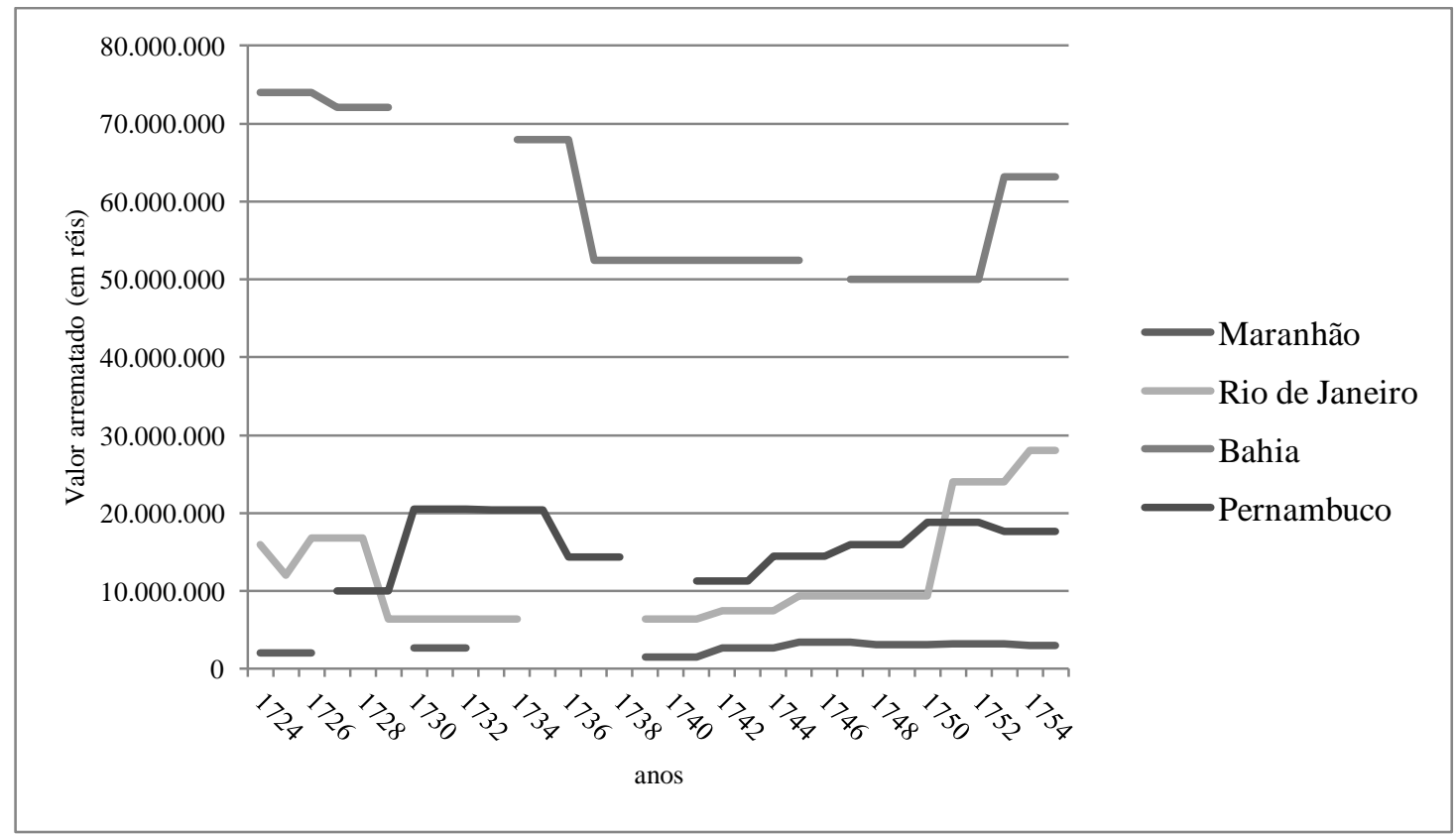

É clara a pouca produtividade da economia amazônica, comparada ao que se produzia no Estado do Brasil. Os dízimos maranhenses são muito baixos, inclusive quando comparamos com o Rio de Janeiro, que na primeira metade do século XVIII ainda não gozava do protagonismo que passaria a ter como sede do governo-geral em 1763. Fica ainda mais evidente a posição marginal do Maranhão, quando comparados com os dízimos arrematados no centro de produção açucareira do Estado do Brasil: as capitanias do Nordeste. Isso demonstra, ao fim e ao cabo, uma módica arrecadação refletida por uma exígua produção voltada a economia de exportação.

${ }^{158}$ CARRARA, Ângelo A. \& SANTIRÓ, Ernest S. Historiografia econômica do dízimo agrário na Ibero-América: os casos do Brasil e Nova Espanha, século XVIII. In: Estudos Econômicos. Vol.43; no.1 São Paulo Jan./Mar. 2013. O Gráfico VII foi construído através da base de dados dos dízimos da terra do Maranhão, constituído de vários documentos avulsos do Maranhão. Para ver a lista de documentação, consultar os Anexos. Para os dados dos dízimos do Rio de Janeiro, Bahia e Pernambuco, agradeço ao amigo historiador André Fillipe, por ter cedido os dados coletados em sua pesquisa de mestrado. 
Nesse sentido, pode-se afirmar que ambas as capitanias se encontravam em precária situação, na primeira metade do século XVIII. São inúmeras as correspondências nos avulsos dando conta da falta do básico para que os habitantes pudessem viver dignamente, além de uma melhor organização da produção para que não houvesse concorrência entre os colonos do Maranhão e do Grão-Pará. Isso fica evidente em uma representação feita a D. João V em 14 de agosto de 1741, assinada pelos colonos João Barbosa, João Mendes de Amorim, Simão Gonçalves e Norberto Pereira Veloso, em que relatavam as precárias condições em que viviam no Maranhão porque lhes faltavam meios para produzir, bem como escravos. Reclamavam também de que a inserção da cotonicultura no Grão-Pará derrubou os preços de um dos poucos produtos de exportação do Maranhão, e que isso corroborava para a situação de pouco desenvolvimento econômico da região. ${ }^{159}$

As relações entre os colonos eram atribuladas entre as duas localidades. Desde a criação do Estado do Maranhão, a capital fora São Luís. Em 1737, por questões estratégicas, os Governadores vinham com ordens expressas de se fixar em Belém que se transformou em capital do Estado. A cidade era mais bem estruturada do ponto de vista administrativo e populacional que São Luís, além de ser ponto-chave nos conflitos de fronteiras com os territórios franceses e espanhóis na América. Nesse sentido, houve certa rivalidade entre ambas as cidades, pois não queriam ser controladas pela administração uma da outra, com o argumento de "esquecimento" por parte do aparelho administrativo. No início do XVIII, são várias as solicitações da câmara de São Luís, pela separação do governo de ambas as capitanias. Contudo manteve-se uma administração centralizada, que respondia diretamente a Lisboa. ${ }^{160}$

Os colonos estabelecidos em São Luís reclamavam que o fato das cargas maranhenses terem de passar pelo porto de Belém, para serem completadas com cargas paraenses diminuía a fluidez do comércio da capitania, o que resultava na diminuição da circulação de mercadorias, de moedas - que ficava concentrada no Grão-Pará - bem como na arrecadação. Mas a centralização administrativa visava fortalecer a defesa da região de um inimigo comum a ambas as capitanias: os castelhanos. O Tratado de Madri

\footnotetext{
${ }^{159}$ Arquivo Histórico Ultramarino; Avulsos do Maranhão, Caixa 26, Documento 2697. Representação dos colonos de João Barbosa, João Mendes de Amorim, Simão Gonçalves e Norberto Pereira Veloso, ao rei D. João V de 14 de agosto de 1741.

${ }^{160}$ SANTOS, Fabiano Vilaça dos. O Governo das Conquistas do Norte: Trajetórias Administrativas no Estado do Grão-Pará e Maranhão (1751-1780). São Paulo: Annablume, 2011. (p.64-5).
} 
em 1750 definiu as fronteiras dos dois impérios ibéricos, mas na prática a região fronteiriça do amazonas sempre foi território de tensões. A manutenção da unidade do Império Português na América, nesse sentido, deveria ser uma prioridade e vinha antes do interesse dos colonos ali estabelecidos. ${ }^{161}$

Estabelecer-se em Belém significava uma opção logística, visando facilitar as incursões pelo sertão para tentar demarcar as fronteiras estabelecidas pelo Tratado de Madri, auxiliando com mais agilidade a proteção dessas fronteiras com o Império espanhol, bem como tomando posse de áreas disputadas com os franceses estabelecidos nas Guianas. Na Amazônia sempre se privilegiou os agentes da administração de formação militar, capazes de proteger as fronteiras. As capitanias do Norte eram antes de qualquer coisa, postos militares. ${ }^{162}$

Pensamos que tal fato, ajuda a explicar a estagnação da economia amazônica de 1680 a 1755. A Coroa e administração colonial portuguesa pouco fez em benefício do desenvolvimento econômico das capitanias do Norte, pois o foco inicial era em demarcar e proteger as fronteiras com o Império Espanhol. O que se pode afirmar, a partir dos dados coletados e da documentação analisada, é que para esse primeiro momento apresentado, o que caracteriza a economia da Amazônia Portuguesa é o extrativismo de cacau e de drogas do sertão, baseado na mão de obra indígena, fundamentalmente controlada pela Companhia de Jesus. Vêem-se também alguns esforços particulares para a produção de tabaco e de algodão, principalmente na capitania do Maranhão; contudo não foram bem sucedidas, sobretudo pela dificuldade do acesso ao indígena e pela falta de uma importação regular de escravos africanos.

A tentativa de desenvolver a economia da Amazônia, aliada a essa política de defesa e expansão do território já estabelecida, só começou a tomar forma com a ascensão de D. José I ao trono em 31 de julho de 1750. O Gabinete Josefino encabeçado por Sebastião José de Carvalho e Melo - implementou uma série de reformas do ponto de vista administrativo e econômico, dentre elas a criação da Companhia Geral do Comércio do Grão-Pará e Maranhão. A empresa monopolista vai propiciar a entrada regular de escravos africanos, o estabelecimento de uma produção agrícola um pouco mais relevante do ponto de vista do volume dos produtos e também

${ }^{161}$ SANTOS. Op. cit. (p.64); DIAS, Manuel Nunes. Fomento e Mercantilismo: a Companhia do GrãoPará e Maranhão (1755-1778). Belém: Ed. da UFPA, 1970. (p.34).

${ }^{162}$ SANTOS. Op. cit. (p.66) 
financeiro, bem como da diversificação; somado tudo isso, será observada uma viragem do centro econômico de Belém para São Luís. Tais aspectos serão discutidos no tópico a seguir.

\subsection{A Economia no Estado do Grão-Pará e Maranhão (1756 - 1807)}

\subsubsection{As Políticas Pombalinas e o Comércio de Escravos no Estado do Grão-Pará e Maranhão na Segunda Metade do Setecentos}

O Estado do Grão-Pará e Maranhão foi instituído em 1751, para ser desmembrado em duas unidades administrativas distintas entre 1772 e 1774: o Estado do Grão-Pará e Rio Negro e o Estado do Maranhão e Piauí. É importante compreender que todo esse processo de inserir a Amazônia no sistema colonial português é fruto da implantação e consolidação das políticas pombalinas. ${ }^{163}$ Dentre as medidas pombalinas que foram implementadas na Amazônia, podemos destacar dentre as principais, a extinção da escravidão indígena, com o Diretório dos Índios, transformando-os em vassalos do Rei de Portugal; a restrição do poder clerical, que resultou na expulsão dos jesuítas em 1759; e o desenvolvimento e expansão da produção colonial, com base nas práticas monopolistas, tendo como exemplo cabal a Companhia Geral do Comércio do Grão-Pará e Maranhão.

Para isso, Carvalho e Melo imbuiu alguém de sua extrema confiança, para tocar o desenvolvimento das novas diretrizes políticas e econômicas para a região amazônica. Seu irmão Francisco Xavier de Mendonça Furtado foi o grande responsável por introduzir nas capitanias do norte os projetos de recolonização propostas pelo Gabinete Josefino, encabeçado pelo futuro Marquês de Pombal. Sua missão enquanto governador foi de reconstruir econômica, e administrativamente, a Amazônia portuguesa. Mendonça Furtado assumiu a administração do Estado do Grão-Pará e Maranhão em 24 de setembro de 1751, e era visto com certa ambigüidade por seus contemporâneos: alguns o enxergavam como grande administrador colonial, que

${ }^{163}$ SANTOS. Op. cit. (p.30-31). 
estabeleceu o domínio português nas capitanias do norte e desenvolveu o comércio e a produção de gêneros. Outros já o vêm como um arremedo de seu irmão. ${ }^{164}$

Contudo, a pouca produção historiográfica contemporânea sobre a região, tem salientado a importância do papel reformador de Mendonça Furtado. Fora a ponta de lança das políticas pombalinas para o Império Português, o que proporcionou a retomada do projeto colonizador na Amazônia. Sua experiência como militar atuante nos conflitos da Colônia do Sacramento, foi fator importante e valorizado para que assumisse como administrador das capitanias do norte, pois já estava familiarizado com os problemas de fronteiras. Observa-se então, que Mendonça Furtado possuía predicados mais relevantes do que apenas ser irmão de Carvalho e Melo.A ação colonizadora de Mendonça Furtado era naquele momento, fortificar, delimitar, povoar e desenvolver as capitanias do Norte. ${ }^{165}$

A política josefina para a colonização da Amazônia era de expandir e ocupar a região, tendo em vista as novas resoluções demarcatórias das fronteiras propostos pelo Tratado de Madri, firmado em 13 de janeiro de 1750. A preocupação, com uma possível ocupação espanhola na região amazônica, forçou a Coroa a tomar a atitude de desenvolver e ocupar a região. O centro administrativo sempre esteve no Maranhão e uma das primeiras medidas de Mendonça Furtado foi transferir a administração para Belém, de onde era possível monitorar a foz do Amazonas, principal via de acesso ao interior do continente, além de estar em uma posição de centralização geográfica, com a criação da capitania de São José do Rio Negro e da proximidade com as minas de Goiás e Mato Grosso. ${ }^{166}$

Além disso, o tratamento dado ao indígena pelos colonos e pelos religiosos na região amazônica era uma preocupação axiomática do Gabinete Josefino. Nas instruções régias para Mendonça Furtado, de maio de 1751, D. José I dedicou dezessete de trinta e oito tópicos - do $2^{\circ}$ ao $18^{\circ}$ - para tratar da questão do cativeiro e da exploração da mão de obra indígena. Demonstrou insatisfação com o não cumprimento da Lei de primeiro de abril de 1680 que proibia a escravização do nativo, graças a algumas lacunas propiciadas pelo alvará régio, com força de Lei, de 28 de abril de 1688

\footnotetext{
${ }^{164}$ SANTOS. Op. Cit. (p.32).

${ }^{165}$ Idem. (p.62).

${ }^{166}$ MAGALHÃES Joaquim Romero. Labirintos Brasileiros. São Paulo: Alameda, 2011. (p.203)
} 
que permitia em alguns casos - como índios capturados em confrontos e guerras justas - sua escravização.

No item $6^{\circ}$, D. José I explicita que

Para conter estes desordenados procedimentos e evitar tão considerável dano, sou servido a declarar que nenhum destes índios possa ser escravo, por nenhum princípio ou pretexto, para o que hei por revogadas todas as leis, resoluções e provisões que até agora subsistiram e quero que só valha esta minha resolução que fui servido tomar no decreto de 28 do corrente [maio de 1751], que baixou ao Conselho Ultramarino para que todos os moradores do Estado [GrãoPará e Maranhão] cuidem em fábrica as suas terras como se usa no [Estado do] Brasil, ou pelo serviço dos mesmos índios, pagando estes os seus jornais e tratando-os com humanidade, sem ser, como até agora se praticou, com injusto, violento e bárbaro rigor. ${ }^{167}$

As instruções são claras: o indígena não pode ser mais tratado como escravo e deve ser regularmente pago pelos serviços prestados aos colonos. Contudo, o Rei, no sétimo item das instruções, apontou para o que seria a solução para resolver dois problemas: a proibição do cativeiro ao nativo e a falta de mão de obra evidente na região: os colonos deveriam servir-se de escravos africanos. Nesse sentido,

A questão da mão de obra tinha de ser resolvida de outro modo que não por meio da escravização de índios. Tornava-se evidente, também para o Pará, o que em Pernambuco cedo se constatara: era indispensável trazer escravos da África. ${ }^{168}$

Destarte, a ideia da Coroa era que os jesuítas organizassem o tráfico de escravos na região, ao mesmo tempo em que seriam responsáveis pela libertação dos indígenas do cativeiro. Mas as relações sociais existentes na região amazônica, dificultaria a execução de tal ordem. Os jesuítas, que controlavam principalmente a região do Pará, impunham dificuldades ao governador e tornou-se uma barreira que

\footnotetext{
${ }^{167}$ MENDONÇA, Marcos Carneiro de. A Amazônia na era pombalina. Brasília: Edições do Senado Federal, 2005. Vol. 1. (p.69)

${ }^{168}$ MAGALHÃES. Op. Cit. (p. 216-9).
} 
impedia a implantação das novas diretrizes propostas pelo Gabinete Josefino. ${ }^{169}$ E nesse sentido, Mendonça Furtado

[...] estava imbuído da necessidade de impor o reconhecimento da autoridade régia no Estado do Pará e Maranhão sem qualquer restrição ou limite à autoridade do monarca. Fora nomeado para "o estabelecimento de um novo método de governo". ${ }^{170}$

Paralelo ao conflito com os jesuítas, ainda era necessário resolver o problema da inserção da mão de obra africana na região. Nesse sentido, o sucesso do empreendimento escravista no Estado do Brasil passou a ser utilizado como argumento para fomentar o tráfico para o Estado do Grão-Pará e Maranhão. Como visto anteriormente, observamos que em ambas as capitanias existiam uma economia exportadora frágil, baseada numa pequena produção de tabaco no que diz respeito ao Maranhão, e no Grão-Pará uma produção baseada no extrativismo de cacau e outras drogas do sertão (em menor escala), ambas bastante dependentes da mão de obra do nativo. E no intuito de desenvolver a região, a Coroa delegou a Mendonça Furtado, no item décimo primeiro das instruções ao Governador, que fizesse um estudo sobre a viabilidade da introdução de africanos no Estado, como por exemplo, a quantidade necessária de mão de obra africana para desenvolver as lavouras, a quantidade que seria possível importar, formas de como pagar pelos escravos, entre outras coisas.

A alternativa encontrada por Mendonça Furtado foi unir os poucos colonos e comerciantes estabelecidos no Pará e no Maranhão e assim criar uma companhia monopolista - que contou com apoio de seu irmão, Ministro de Estado. Entretanto, devido ao fato de ser uma região de economia pouco relevante, não foi possível juntar recursos financeiros necessários para a formação de uma empresa que pudesse fomentar o tráfico de africanos para as ditas capitanias. Assim, com o fracasso desse primeiro empreendimento, Pombal articulou os homens de negócio estabelecidos em Lisboa, e em 1755 foi enviada petição a D. José I, para que fosse fundada a empresa de caráter monopolista, que teria por objetivo fomentar o tráfico de escravos africanos para as

\footnotetext{
${ }^{169}$ MENDONÇA. Op. Cit. (p. 281-298).

${ }^{170}$ MAGALHẪES. Op. Cit. (p. 202).
} 
capitanias do Pará e do Maranhão, bem com estimular a produção de gêneros coloniais e a coleta de drogas do sertão na região. ${ }^{171}$

Sendo assim, em seis de junho de 1755, estava instituída a Companhia Geral do Comércio do Grão-Pará e Maranhão. O primeiro signatário, identificando-se como homem de negócio da praça de Lisboa, era o próprio Carvalho e Melo. Tinham o interesse pelo "bem comum, e conservação daquele Estado [Grão-Pará e Maranhão]: tem convindo em formarem para ele uma nova Companhia, que cultivando o seu comércio, fertilize ao mesmo tempo por este próprio meio a agricultura, e a povoação que nele se acham em tanta decadência." ${ }^{172}$ Para que a agricultura e o comércio expandisse, o colonos estabelecidos na Amazônia compreendiam a necessidade de "escravos negros, de cujo serviço se tem seguido tantas utilidades aos outros domínios de V. Majestade na América Portuguesa.",173

Nesse sentido, no Artigo $30^{\circ}$ da Instituição da Companhia, era solicitado que

[...] só ela [a Companhia] possa exclusivamente introduzir os escravos negros nas sobreditas duas Capitanias [Grão-Pará e Maranhão] e vendê-los nelas no preço em que se ajustar, pagando os costumados direitos à Real Fazenda de V. Majestade. ${ }^{174}$

O que se observou, é que diferente de sua congênere do final do século XVII, a Companhia pombalina conseguiu estabelecer um trato regular de escravos para a Amazônia, que continuou a existir mesmo com o fim de seu monopólio comercial em 1778. A tabela XVII abaixo ilustra o movimento do tráfico de escravos africanos para Amazônia, no período entre 1756 e 1807, dividido em qüinqüênios:

${ }^{171}$ CARREIRA. Op. Cit. (p.52); MAGALHÃES. Op. cit. (p.217)

${ }^{172}$ Instituição da Companhia do Grão-Pará e Maranhão. Apud. CARREIRA. Op. Cit. 1988. (p.09)

173 Idem. (p.18)

${ }^{174}$ Idem. 
Tabela XVII. Escravos Introduzidos na Amazônia (1756-1807)

\begin{tabular}{|c|c|}
\hline Qüinqüiênios & Escravos \\
\hline $1756-60$ & 4.182 \\
\hline $1761-65$ & 6.787 \\
\hline $1766-70$ & 5.281 \\
\hline $1771-75$ & 5.224 \\
\hline $1776-80$ & 8.213 \\
\hline $1781-85$ & 6.400 \\
\hline $1786-90$ & 10.090 \\
\hline $1791-95$ & 9.859 \\
\hline $1796-1800$ & 8.044 \\
\hline $1801-1807$ & 25.056 \\
\hline TOTAL & $\mathbf{8 9 . 1 3 6}$ \\
\hline
\end{tabular}

Fonte: The Trans-Atlantic Slave Trade Database. Disponível em http://www.slavevoyages.org/, acesso em 10/07/2012. Filtros utilizados: Time Frame > 1756 - 1807; Principal place of slave landing > Brazil > Amazonia > Maranhão > Pará.

Os dados coletados demonstram que foram introduzidos nos portos amazônicos 89.136 escravos no período analisado, quase 39 vezes mais do que no período abordando anteriormente, entre 1680 e 1755. Enquanto que nestes setenta e cinco anos anteriores a criação da Companhia Pombalina, eram introduzidos pouco mais de trinta escravos por ano, temos que após a criação da empresa monopolista essa média saltou para cerca de pouco mais de 1.747 escravos por ano. Outro ponto a ser observado é que existe uma tendência de crescimento no volume de escravos na longa duração, como podemos observar no gráfico abaixo: 
Gráfico VIII. Escravos Introduzidos na Amazônia (1756-1807)

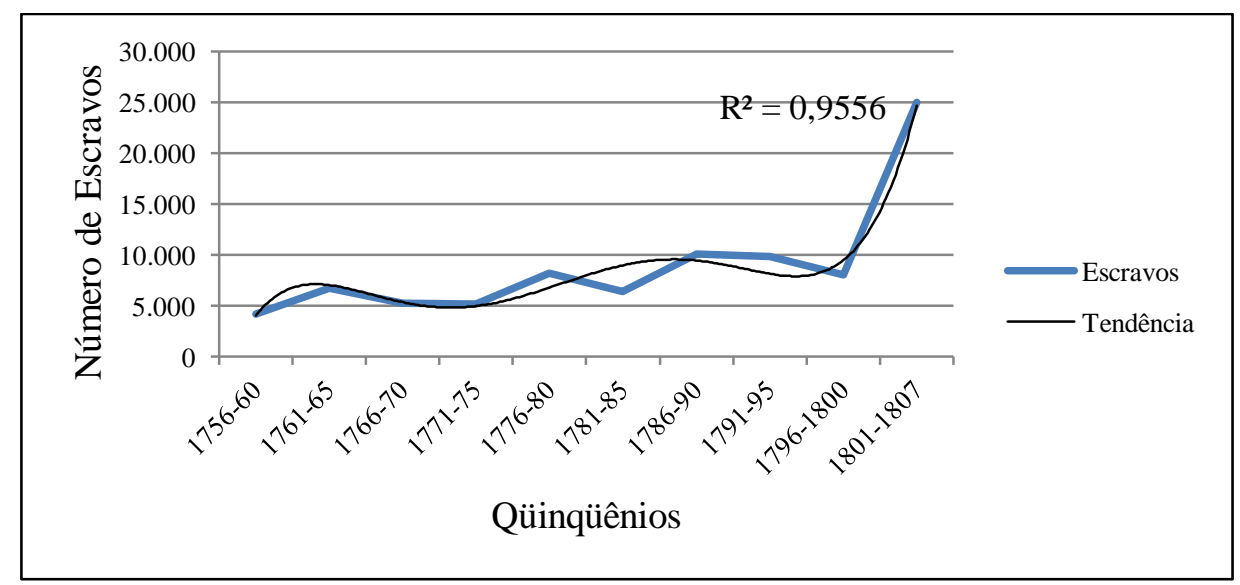

O gráfico sugere flutuação. Mas a linha de tendência demonstra um período compreendido entre 1766 e 1780 de uma pequena baixa, e um crescimento substancial a partir do qüinqüênio entre 1781 e $1785 .^{175}$ Mas o que mais chama a atenção e o crescimento vertiginoso, na virada para o século XIX, no período compreendido entre 1801 e 1807, quando foram introduzidos por volta de $28 \%$ dos escravos para todo o recorte analisado. O fato é explicado pela volta do tráfico de escravo nos portos de Angola e outras regiões negreiras na costa ocidental da África, como Costa da Mina e Benin.

Os Extratos de Carregações da Companhia revelam um baixo custo dos escravos de Angola em relação aos resgatados na área da Guiné. O que causa estranhamento em um primeiro momento é que com preços mais baixos em Angola, a Companhia poderia ter uma maior lucratividade, pois os escravos seriam vendidos ao mesmo preço dos de Guiné. No entanto, o comércio com Angola é deixado de lado, preterido por Bissau. E a pergunta que fica é: por quê? Sabe-se que até 1759 a Companhia atuava principalmente em duas regiões africanas de comércio negreiro: rios da Guiné e Angola. A partir do ano acima citado a Companhia abandonou intencionalmente o mercado angolano, deixando-o livre para a sua associada - a Companhia Geral do Comércio de Pernambuco e da Paraíba - que os vendia a preços

\footnotetext{
${ }^{175}$ Foi escolhida uma linha de tendência polinomial, pois os dados analisados flutuam consideravelmente, sendo muito útil para analisar as entradas dos escravos nos portos amazônicos, tendo em vista que é em um conjunto de dados relativamente grande. A opção foi por uma tendência polinomial de ordem 5 , tendo em vista que o gráfico apresenta cinco picos. Além disso, o $\mathrm{R}^{2}$ é de 0,955 , o que revela um bom ajuste da linha dos dados.
} 
maiores no Recife, já que muitos desses escravos eram repassados para a região das minas. A compensação, para ambas, seria mais vantajosa.

Contudo, com o fim das Companhias o que se percebe é a retomada do mercado angolano, por parte dos comerciantes que introduziam escravos no Grão-Pará e Maranhão. Sem o monopólio do tráfico de escravos, os mercadores que assumem o negócio estão livres para buscar escravos, onde estes são mais baratos e podem render maiores lucros. ${ }^{176}$ Ao analisar os dados, pode-se observar como se deu o tráfico de escravos para a Amazônia durante e após a extinção do monopólio da Companhia:

\section{Gráfico IX: Comparação entre a origem dos escravos introduzidos na Amazônia no período de monopólio da CGGPM (1756-1778) e após a sua extinção (1779-}

1807)

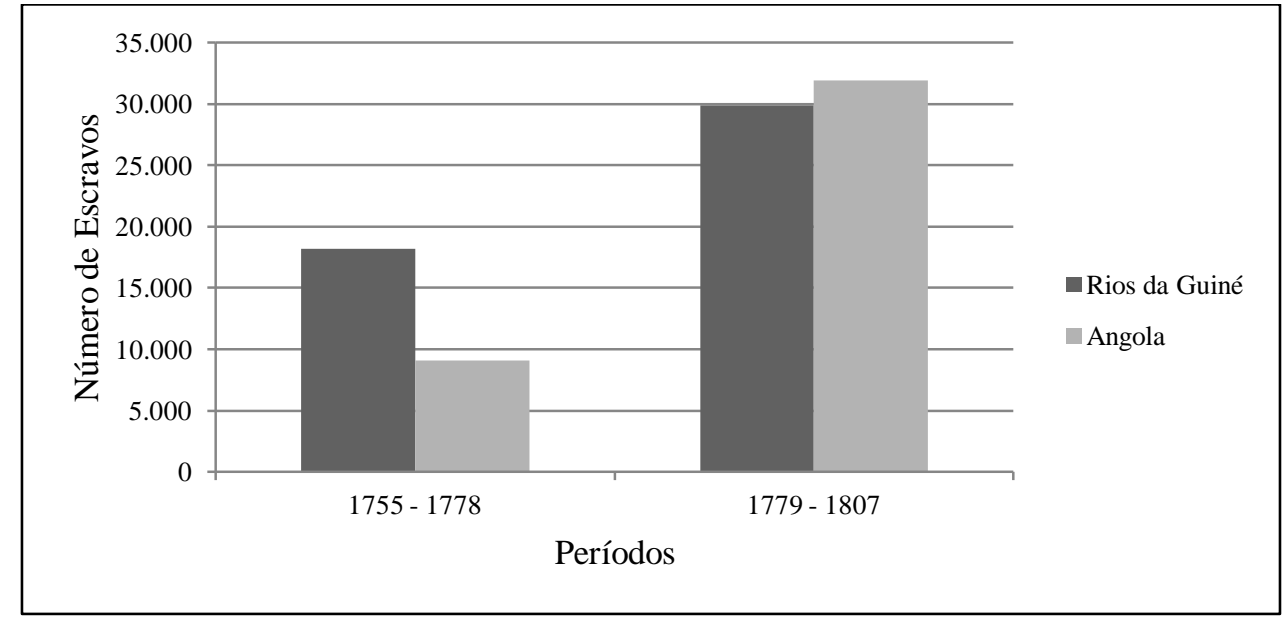

O que o gráfico ilustra é que no período em que a Companhia exerceu o monopólio no tráfico de escravos, os portos dos Rios da Guiné foram preponderantes nas remessas de peças para a Amazônia: 66,8\% dos escravos. Contudo, o fato que melhor demonstra como a empresa pombalina "abandonou" o comércio em Angola e outros portos da África Ocidental é que a última remessa vinda de Luanda data de 1765, na embarcação São Luís Rei da França, de propriedade da própria Companhia. ${ }^{177}$ Já com o fim do monopólio, os portos da Guiné Portuguesa passam a dividir a remessa com outros portos da costa oeste africana, que passam a enviar maior número de escravos para os portos de Belém e São Luís, sobretudo Luanda e Benguela: no caso,

\footnotetext{
${ }^{176}$ CARREIRA. Op. Cit. 1988. passim

${ }^{177}$ Fonte: Base de dados montada através do Database Slave Trade, disponível em: www.slavevoyages.org. Número de identificação da viagem 8949.
} 
temos que no período entre 1779 e $1807,51,66 \%$ dos escravos introduzidos nos portos amazônicos eram oriundos de Angola e outros portos da África, e 48,34\% vieram dos Rios da Guiné. ${ }^{178}$

Entretanto, quando se separa o período após o fim do monopólio em dois, percebe-se que os anos iniciais do século XIX (1801-1807), são fundamentais para entender a mudança de importância entre os portos africanos de tráfico que introduziam escravos na Amazônia, dos Rios da Guiné para Angola. O gráfico abaixo ilustra a afirmação:

\section{Gráfico X: Comparação entre a origem dos escravos introduzidos na Amazônia após o fim do monopólio da CGGPM, dividido em dois períodos: de 1779 a 1800 e de 1801 a 1807}

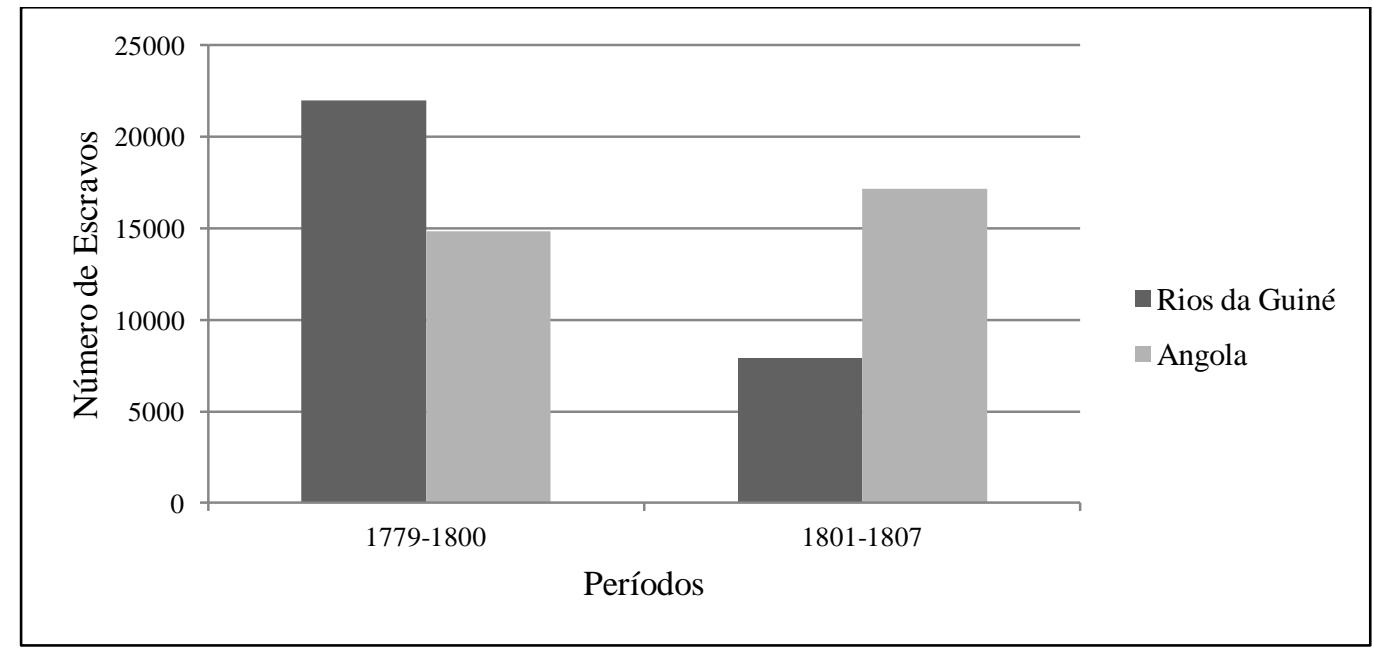

O importante, ao observar os dados acima, é que Bissau continuava sendo o principal entreposto de tráfico de escravos para São Luís e Belém, até pelo menos a viragem para o século XIX. No período inteiro, Angola superava por uma pequena margem os Rios da Guiné em escravos introduzidos na Amazônia - cerca de 3,3\%. Nesse período, temos que apenas 7.916 peças tiveram origem nas feitorias de tráfico dos Rios da Guiné: ou seja, 17.140 africanos - ou quase 69\% - tiveram sua origem fundamentalmente de Luanda. Não há na documentação, nada que possa assegurar essa viragem; mas José Joaquim de Souza Trovão, em carta de fevereiro de 1802, falava do

\footnotetext{
${ }^{178}$ Há algumas poucas remessas vindas do Porto da Ajuda, Benin, Costa da Mina, Gabão e outros portos menores da Costa da África Ocidental.
} 
total abandono da Praça de Cacheu e da falta de dinheiro para pagamento dos filhos da folha, pois há quase um ano e meio não aportavam navios. ${ }^{179}$

Em Bissau, informações passadas pelo capitão-mor Manoel Pinto da Gouveia dizia que a presença portuguesa era bem exígua em São José de Bissau, o que proporcionava facilidades aos comerciantes de outras nações que contrabandeavam escravos, cera e marfim por essas localidades com pouca fiscalização. Solicitava o envio de pessoas para povoamento dessas regiões, mas em 1806, por exemplo, existiam na praça nos arredores da feitoria, aproximadamente 638 habitantes, contando a escravaria. Havia 168 habitações de súditos portugueses, o que demonstrava a diminuta ocupação por parte de colonos portugueses. Nesse sentido, os apontamentos de ambos os capitãesmores demonstram que no início do Oitocentos, as feitorias da Guiné estavam em estado de abandono e que poucos comerciantes portugueses se interessavam em comerciar escravos na região. ${ }^{180}$

Sendo assim, o que pode ser observado é que com as políticas pombalinas de extinção do cativeiro indígena e a criação da Companhia Geral do Comércio do GrãoPará e Maranhão, se assistiu ao aumento significativo do tráfico de escravos para a Amazônia. A introdução do negro africano e da escravidão, nas capitanias do norte da América Portuguesa, vai modificar sobremaneira as relações sociais e principalmente a produção para exportação da região. É o que será tratado no tópico a seguir.

\subsubsection{O Tráfico de Escravos nos Rios da Guiné e a Produção Amazônica na Segunda Metade do Setecentos}

Neste item discutiremos como a introdução do escravo africano, utilizando como base os dados do tráfico de escravos nos Rios da Guiné - que é o foco dessa pesquisa - proporcionou uma mudança estrutural no sistema produtivo. De uma economia, quase que exclusivamente, extrativa baseada na mão de obra nativa, a Amazônia passava agora a receber um contingente significativo de negros africanos, reestruturando a economia: na segunda metade do século XVIII, além das atividades

\footnotetext{
${ }^{179}$ Arquivo Histórico Ultramarino. Avulsos da Guiné, Caixa16, documento 38. Carta do capitão-mor da Praça de Cacheu José Joaquim de Souza Trovão, de 03 de fevereiro de 1802.

${ }^{180}$ Arquivo Histórico Ultramarino. Avulsos da Guiné, Caixa 18, documentos 43 e 65. Ofícios do capitãomor da Praça de São José de Bissau Manoel Pinto da Gouveia, de 20 de novembro de 1805 e de 21 de maio de 1806.
} 
extrativas - que não foram deixadas de lado - o foco era implementar a produção agrícola e pastoril na região. Entre 1756 e 1807, foram introduzidos 47.877 escravos com origem nos portos de Bissau, Cacheu e Cabo Verde. Divididos em qüinqüênios, temos que:

Tabela XVIII. Escravos com origem nos Rios da Guiné, introduzidos na Amazônia (1756-1807

\begin{tabular}{|c|c|}
\hline Qüinqüiênios & Escravos \\
\hline $1756-59$ & 1.111 \\
\hline $1760-64$ & 3.434 \\
\hline $1765-69$ & 4.632 \\
\hline $1770-74$ & 5.107 \\
\hline $1775-79$ & 4.702 \\
\hline $1780-84$ & 3.899 \\
\hline $1785-89$ & 4.962 \\
\hline $1790-94$ & 7.005 \\
\hline $1795-99$ & 5.109 \\
\hline $1800-04$ & 3.043 \\
\hline $1805-07$ & 4.873 \\
\hline TOTAL & $\mathbf{4 7 . 8 7 7}$ \\
\hline
\end{tabular}

Fonte: The Trans-Atlantic Slave Trade Database. Disponível em http://www.slavevoyages.org/, acesso em 10/07/2012. Filtros utilizados: Time Frame > 1756 - 1807; Principal place of slave landing > Brazil > Amazonia > Maranhão > Pará.

Mesmo com a flutuação dos números, percebe-se que a entrada de escravos foi bastante regular no período, com exceção do qüinquiênio 1790 a 1794, que teve um salto considerável de 4.962 para 7.005 africanos. Contudo, é apenas dez anos após a criação da Companhia de Comércio, é que vai se observar o resultado da inserção da mão de obra africana nas lavouras. A Amazônia passou a exportar, após meados da década de 1760, cada vez mais produtos agrícolas dentre os quais se destacam em volume e valores o arroz e o algodão; isso sem contar o estímulo dado à pecuária para a produção de peles, pois também eram exportadas grandes quantidades de couro em cabelo, 
vaquetas e solas. Contudo, pretende-se analisar nesse primeiro momento, o impacto da escravidão na mudança do sistema produtivo amazônico. Sendo assim, o gráfico abaixo ilustra como se deu o estímulo a produção no Estado do Grão-Pará e Maranhão: ${ }^{181}$

\section{Gráfico XI. Flutuação entre os principais produtos amazônicos exportados e a} introdução de escravos (1760-1807) (em toneladas)

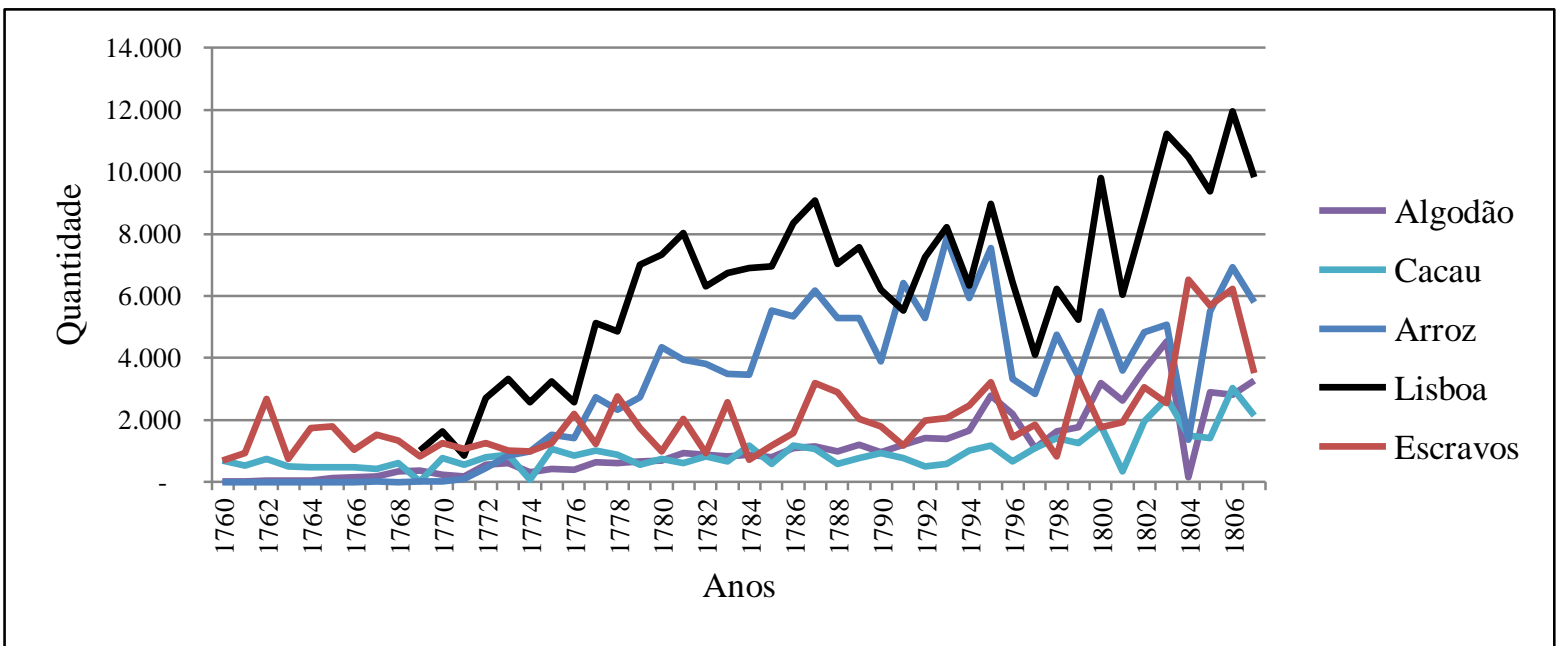

O que se observa é que mesmo com uma economia instável e com muita flutuação, o tráfico de escravos regular permitiu a expansão da produção agrícola dos principais produtos de exportação: o arroz e o algodão. Note-se também que as exportações no geral para Lisboa, também tende a acompanhar os movimentos de alta e baixa da introdução de escravos africanos. Outro fato importante a ser observado é que a produção cacaueira se mantém estável durante quase todo o período, tendo uma pequena alta a partir dos primeiro anos do século XIX.

Tais constatações corroboram o fato de que o tráfico de escravos africanos, e conseqüentemente a escravidão, são fundamentais para o desenvolvimento da produção agrícola nas capitanias do norte da América Portuguesa. De uma economia pouco relevante até a primeira metade do século XVIII, começa-se a produzir gêneros importantes, pois no contexto da Revolução Industrial o algodão passa a possuir um protagonismo no mercado europeu; e como Portugal sempre fora deficitário na produção de cereais, cargas regulares de arroz tinham sua relevância para o Reino.

${ }^{181}$ Para o gráfico, utilizamos nossa base de dados montada através de vários documentos tabulados nos documentos avulsos do Pará e do Maranhão. Para consultar a documentação, ver Anexos. Foi adotado toneladas, ao invés de arrobas, para permitir a comparação com o número de escravos no mesmo gráfico. Nesse sentido, 1 tonelada equivale a 68,08 arrobas. 
Contudo, esse efeito positivo do tráfico na cotonicultura e na rizicultura não foi observado nas exportações de cacau e a explicação é simples: a extração do cacau e das demais drogas do sertão continuava organizada da mesma forma, que era através da mão de obra indígena remunerada. Do ponto de vista financeiro, também se observa um crescimento dos valores exportados a partir de 1760. Vejamos o gráfico abaixo: ${ }^{182}$

Gráfico XII: Relação entre a entrada de escravos africanos e os valores das exportações totais da Amazônia (1760-1807)

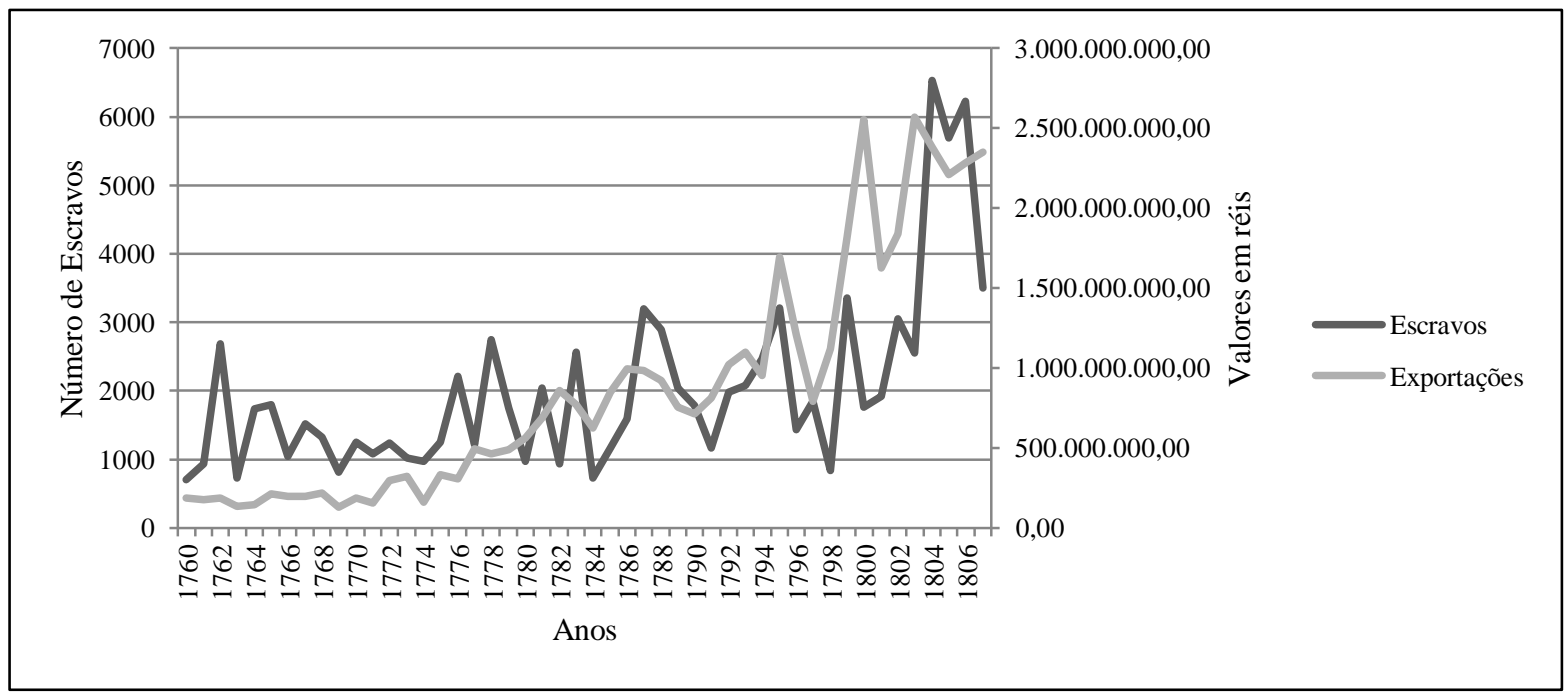

O gráfico acima demonstra um crescimento considerável no volume financeiro, referente às exportações amazônicas, principalmente a partir de meados da década de 1770. Contudo, é só na década de 1790 que comparativamente as exportações superaram as entradas de escravos. A explicação para esses fatos é que, como visto, antes da chegada do africano, a economia amazônica era baseada fundamentalmente no extrativismo. A produção de algodão e tabaco existente no final do século XVII e na primeira metade do XVIII era exígua. Até que o processo de remodelação da produção agrícola começasse a dar frutos, levaria algum tempo: como dito anteriormente, pelo menos dez anos separaram o estímulo dado pela política pombalina e a consolidação de uma cultura agrícola na região.

Percebe-se que, mesmo a Amazônia ainda sendo uma zona econômica marginal em comparação ao Estado do Brasil, as políticas de estímulos à produção que foram propostas pelo Gabinete Josefino, propiciou resultados positivos para a região. É

\footnotetext{
${ }^{182}$ Para o gráfico, utilizamos nossa base de dados montada através de vários documentos tabulados nos documentos avulsos do Pará e do Maranhão. Para consultar a documentação, ver Anexos.
} 
nítido através dos dados apresentados, que a entrada regular de mão de obra oriunda dos Rios da Guiné - e também de outros portos africanos - proporcionou uma mudança no sistema produtivo amazônico. De uma economia quase que exclusivamente extrativa, baseada na mão de obra indígena até meados do século XVIII, temos na segunda metade desse mesmo século a organização e a expansão da produção aos moldes do Estado do Brasil: plantéis de escravos africanos, cultivando a terra e produzindo gêneros que eram interessantes a economia metropolitana e européia no período.

Fator fundamental para tal expansão da produção se deu, sem dúvidas com formação da Companhia Geral do Comércio do Grão-Pará e Maranhão, "fenômeno fundamental para a compreensão da economia atlântica luso-brasileira na segunda metade do século XVIII" ${ }^{\prime 183}$. Com o objetivo de fomentar o tráfico de escravos africanos para as capitanias do Pará e do Maranhão, estimulou a produção de gêneros coloniais e a coleta de drogas do sertão, da qual também se beneficiara. Além disso, ainda atendia o intuito da Coroa descolonizar e proteger uma área de fronteira com o Império Espanhol e cobiçado pelas outras potências européias. E mesmo com a extinção do monopólio em 1778, observamos que a organização mercantil continua a existir de maneira parecida, apenas com a entrada dos antigos entrepostos do tráfico de escravos, anteriormente preteridos.

Mas, a introdução de escravos africanos e a mudança no sistema de produção na Amazônia, se deram de maneira distinta nas capitanias do Grão-Pará e do Maranhão. Essas especificidades serão demonstradas e discutidas nos dois tópicos que se seguem.

\subsection{A Economia Maranhense (1760-1807)}

O Maranhão era uma das quatro capitanias que formavam a Amazônia Portuguesa e procurava dividir a hegemonia política e econômica da região, com a capitania do Grão-Pará. Sua variação climática e vegetal permitiu uma diversificação na produção agrícola: grande parte do território maranhense, próximo ao litoral, é coberto por floresta amazônica, campos e cerrado. Tal fato permitia a coleta de drogas do sertão na porção amazônica e a atividade agropastoril nos campos e cerrado. As altas temperaturas anuais, com duas estações do ano bem definidas - uma seca, que coincide

${ }^{183}$ DIAS. Op. cit. (p.19) 
com o inverno e outra bastante úmida, com cerca de 1.500 a $2.000 \mathrm{~mm}$ de chuva, durante o verão. ${ }^{184}$

Os dados referentes aos produtos exportados pelo porto de São Luís, entre os anos de 1760 e 1807, demonstram bem a variedade da produção agropecuária da capitania. Havia remessas de mantimentos, courama, drogas do sertão, madeira e algodão. Esse último, sem dúvidas, o mais importante dos produtos maranhenses. A fibra têxtil já era bem conhecida dos indígenas, antes da chegada do colonizador europeu na Amazônia. Destarte, sua produção foi relegada a produção de tecidos de pouca qualidade, para a vestimenta dos próprios indígenas, dos poucos escravos africanos que chegaram à região e a população livre e pobre. ${ }^{185}$

Até a criação da Companhia do Comércio, não havia produção expressiva. Contudo, com as novas demandas pela fibra têxtil, em decorrência da Revolução Industrial na Inglaterra, o algodão passou a figurar como matéria-prima estratégica e "as condições de cultivo na colônia e a situação favorável do algodão no mercado consumidor mundial eram razões suficientes para explicar a política fomentista da Coroa". ${ }^{186}$ Aqui, deve-se ter em conta o período de instabilidade vivido pela Inglaterra e dois pontos são fundamentais, para que o algodão alcançasse por volta de $24 \%$ das exportações totais da América Portuguesa na década de 1780, perdendo apenas para as exportações de açúcar: a Guerra de Independência dos Estados Unidos, que começara em 1775, estimulou a produção em outras regiões, haja vista a melhoria dos preços com a diminuição da produção norte-americana da matéria-prima, devido aos conflitos; outro ponto importante foi os conflitos com a França de Napoleão Bonaparte, que prejudicou o fornecimento vindo das Índias Ocidentais e abriu ainda mais espaço para o algodão maranhense na economia atlântica. ${ }^{187} \mathrm{O}$ gráfico abaixo ilustra o fato:

\footnotetext{
${ }^{184}$ Manual Compacto de Geografia do Brasil. São Paulo: Ridel, 2010.

${ }^{185}$ SERRÃO, Joel \& MARQUES, A. H. de Oliveira. Op. Cit. (p. 102). DOURADO, José Ribamar \& BOCLIN, Roberto Guimarães. A Indústria do Maranhão: um Novo Ciclo. Brasília: IEL, 2008. (p.34). A opção pelo recorte entre os anos de 1760 a 1807 , se explica pelo fato de que a série relativa às quantidades e valores dos produtos maranhenses só tem início e está completa a partir de 1760. Os valores para o período entre 1756 e 1759 - quando passa a valer o monopólio da Companhia de Comércio - são desconhecidos. Não os encontrei nos Livros Contábeis da Companhia, disponíveis no Arquivo Nacional da Torre do Tombo, assim como não estão disponíveis nas obras de António Carreira e Manuel Nunes Dias. Cf. CARREIRA. Op cit. 1988. Passim; DIAS. Op. Cit. Passim.

${ }^{186}$ DIAS. Op. Cit. (p.370).

${ }^{187}$ Idem. SERRÃO \& MARQUES. Op. Cit. (p. 102). Para o gráfico, utilizamos nossa base de dados montada através de vários documentos tabulados nos documentos avulsos do Pará e do Maranhão. Para consultar a documentação, ver Anexos.
} 
Gráfico XIII. Exportação do Algodão Maranhense (1760-1807) (em arrobas)

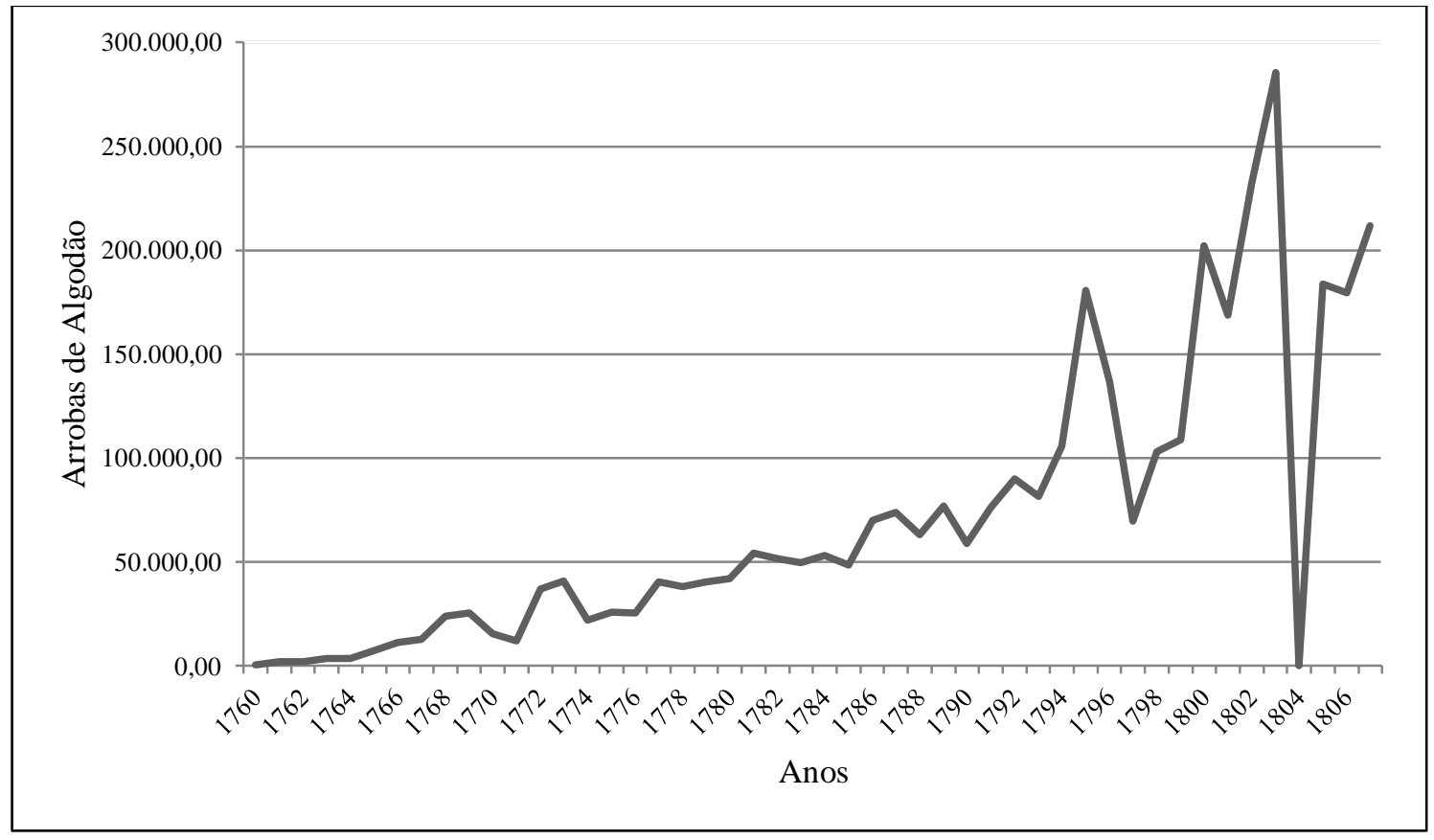

O gráfico mostra grande expansão das exportações de algodão a partir da década de 1780, justamente no auge dos conflitos de Independência nos Estados Unidos. Observe também que na virada para o século XIX, as remessas crescem ainda mais, exatamente no período de acirramento dos conflitos iniciados por Bonaparte, apenas com exceção de 1804 quando não houve frota do Maranhão para Lisboa. Nesse sentido, entende-se porque aos poucos o algodão vai assumindo o protagonismo da economia maranhense. Protagonismo esse, que vai durar até pelo menos a terceira década do Oitocentos.

No que diz respeito ao cultivo do algodão a erva se adaptava melhor às regiões de clima mais seco e com precipitação de chuvas periódicas. Isso acabava afastando a cotonicultura das terras e climas mais favoráveis a cana de açúcar, por exemplo, ocupando áreas até então marginais da América Portuguesa. No Maranhão as lavouras se organizavam de modo bastante semelhante ao das lavouras de cana: grandes porções de terra e mão de obra escrava. Durante a fase de crescimento e amadurecimento não despendia muitos esforços: cerca de três limpezas ao ano. Contudo na fase de colheita, exigia-se grande mobilização de mão de obra, ou seja, a necessidade de um plantel de 
escravos considerável: algo pouco comum na Amazônia, o que acabava restringindo a produção. $^{188}$

A lavoura maranhense era organizada com cerca de 50 escravos, pouco suficiente para os períodos de colheita. ${ }^{189}$ Não havia beneficiamento do produto, como descaroçar e fiar. O algodão era colhido e exportado em forma de rama e cabia aos fabricantes europeus a tarefa do descaroçamento, pois

[...] um escravo descaroçava 1 libra (435 gramas)por dia de trabalho, enquanto que nos Estados Unidos, o descaroçador mecânico de Eli Whitney, inventado em 1793, descaroçava $160 \mathrm{~kg}$ de algodão por dia. $^{190}$

Isso vem demonstrar a pouca especialização da produção, já que o produto era vendido em estado bruto. Até 1807 não se encontra nenhuma menção na documentação sobre melhorias na produção, ou envio de máquinas de descaroçar. Tudo se resumia a cultivo, colheita e envio da fibra para o Reino. O contrário, no entanto, serve à produção de arroz. A introdução da rizicultura na região se deu a partir do ano de 1766 e foi de iniciativa da Companhia de Comércio, na tentativa de competir com importação de mercados estrangeiros, sobretudo da Carolina. Dias ainda aponta para uma produção próspera e que o arroz branco produzido na região era de melhor qualidade do que os importados.No entanto, foi a partir de 1770 que a produção de arroz alcançou o status de um dos principais produtos agrícolas de exportação, graças às inovações no cultivo em larga escala e também ao desenvolvimento da própria região que passou a contar com maior número de escravos e de moinhos para o beneficiamento: ou seja, especializou-se a produção, para a exportação do produto já pronto para o consumo. ${ }^{191}$

O arroz, assim como o algodão, também já era um produto conhecido dos indígenas bem antes da chegada do colonizador. A variação nativa era chamada de arroz Vermelho ou Veneza, considerado de pouca qualidade pelos administradores e capitãesmores. Tentou-se introduzir sem sucesso o arroz branco, também chamado de Carolina:

${ }^{188}$ GAIOSO, Raimundo José de Sousa. Compêndio Histórico Político dos Princípios da Lavoura do Maranhão. Rio de Janeiro: LMI, 1970. Passim.

${ }^{189}$ Idem.

${ }^{190}$ SERRÃO \& MARQUES. Op. Cit. (p. 104).

${ }^{191}$ DIAS. Op. Cit. (p.380). VIVEIROS, Jerônimo. História do Comércio do Maranhão. São Luís: AML, 1954. (p.68) 
devido a existência de uma cultura de subsistência do tipo Veneza, os produtores maranhenses tiveram pouco interesse em desenvolver nova lavoura de um produto que já tinha similar na região. ${ }^{192}$

A produção para a exportação começou a ganhar força na década de 1770. Mas é só a partir de meados da mesma década - mais especificamente 1776 - que a produção vai expandir de fato. Neste ano, o Governador Joaquim Melo e Póvoas baixou medida punitiva contra lavradores, escravos e indígenas que produzissem o arroz Vermelho, ao invés do arroz Carolina. Um esforço conjunto entre Governador, Companhia (pouco antes do fim do monopólio) e um colono irlandês chamado Lourenço Belfort estabelecido no Maranhão e possuidor de um moinho para beneficiamento de arroz fez com que, ao menos em quantidade o arroz assumisse como principal carga nas frotas maranhenses para Lisboa ${ }^{193}$. O gráfico abaixo demonstra a evolução da rizicultura na região:

192 BARROSO JÚNIOR, Reinaldo dos Santos. Nas Rotas do Atlântico Equatorial: Tráfico de Escravos Rizicultores da Alta-Guiné para o Maranhão (1770-1800). Dissertação de Mestrado. UFBA, 2009. (p. 80-3). VIVEIROS, Jerônimo. Op. Cit. (p. 76).

${ }^{193}$ BARROSO JÚNIOR, Reinaldo dos Santos. Nas Rotas do Atlântico Equatorial: Tráfico de Escravos Rizicultores da Alta-Guiné para o Maranhão (1770-1800). Dissertação de Mestrado. UFBA, 2009. (p.834). Para o gráfico, utilizamos nossa base de dados montada através de vários documentos tabulados nos documentos avulsos do Pará e do Maranhão. Para consultar a documentação, ver Anexos. 


\section{Gráfico XIV: Exportação de Arroz Carolina (1760-1807) (em arrobas)}

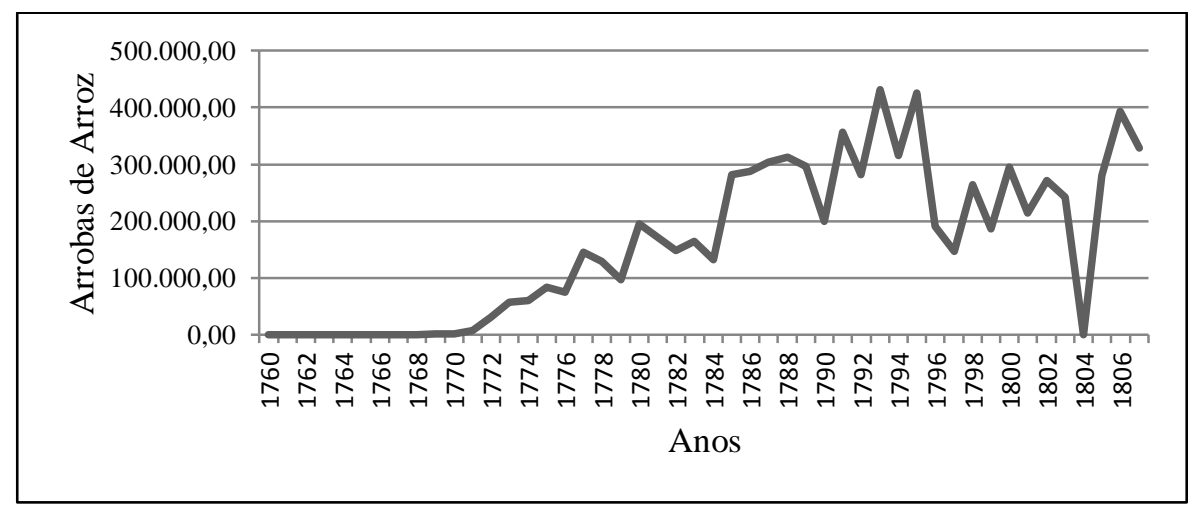

Temos que até o ano de 1766 não houve nenhuma remessa de arroz maranhense para o Reino, ou seja, quase dez anos após a criação da empresa pombalina. Observa-se também que a produção foi muito baixa até pelo menos 1771, com pouco mais sete mil arrobas remetidas. A partir de 1772 a produção começou a expandir, mas só vai ser realmente relevante a partir do ano 1777 quando se remeteu mais de 140 mil arrobas para Lisboa. E tendeu a crescer tendo uma leve queda na segunda metade da década de 1790, recuperando-se parcialmente na viragem para o Oitocentos. Ressalta-se que assim como no caso do algodão, em 1804 não houve exportação de arroz, porque não houve frota para Lisboa.

Pouco sabemos sobre como se organizava a produção, uma vez que não há informações específicas sobre plantéis de escravos ou sistemas de produção. O fato é que existiam na década de 1770 três fábricas de soques bastante modernas para época, que foram fomentadas pela Companhia, bem como algumas centenas de piladores movidos a força eólica e hidráulica. No mais, novos estudos têm apontado para a utilização de escravos africanos especializados na produção de arroz, trazidos dos Rios da Guiné. Esses estudos sugerem que a rizicultura era bastante antiga na Guiné e de bastante importância no tráfico transaariano. ${ }^{194}$

Tal fato leva a ressaltar algo que já foi discutido nos itens anteriores deste capítulo: a fundamental importância do tráfico de escravos atlântico, para a mudança do sistema produtivo da Amazônia, mais especificamente do Maranhão. Como visto anteriormente não houve entrada regular de escravos nas capitanias do Norte da América Portuguesa, até a primeira metade do século XVIII. Com a criação da

\footnotetext{
${ }^{194}$ BARROSO JÚNIOR. Op. Cit. (p. 88-9). VIVEIROS, Jerônimo. Op. Cit. (p. 76).
} 
Companhia de Comércio, já foi observado neste trabalho como se criou uma rota de tráfico regular entre o Estado do Grão-Pará e Maranhão e os portos traficantes dos Rios da Guiné. Já foi sugerida, também neste trabalho, a entrada de 47.877 escravos oriundos de Bissau, Cacheu, Cabo Verde e outros portos menores da Guiné Portuguesa na Amazônia, no período entre 1756 e 1807. Quando observamos os dados apenas para o Maranhão, temos que 35.722 escravos foram introduzidos apenas no porto de São Luís, ou seja, 76,4\% dos escravos guineenses destinados para a Amazônia foram remetidos para as lavouras maranhenses, o que representou $60 \%$ de toda mercadoria viva enviada para o Maranhão no período ${ }^{195}$. A tabela abaixo demonstra a evolução da entrada da escravaria, dividida em qüinqüênios:

Tabela XIX. Escravos Introduzidos no Maranhão, oriundos dos Rios da Guiné (1756-1807)

\begin{tabular}{|c|c|}
\hline Qüinqüênios & Escravos \\
\hline $1756-60$ & 1.107 \\
\hline $1761-65$ & 1.915 \\
\hline $1766-70$ & 3.092 \\
\hline $1771-75$ & 1.308 \\
\hline $1776-80$ & 2.860 \\
\hline $1781-85$ & 2.941 \\
\hline $1786-90$ & 4.742 \\
\hline $1791-95$ & 6.559 \\
\hline $1796-1800$ & 3.635 \\
\hline $1801-07$ & 7.563 \\
\hline TOTAL & $\mathbf{3 5 . 4 7 4}$ \\
\hline
\end{tabular}

Fonte: The Trans-Atlantic Slave Trade Database. Disponível em http://www.slavevoyages.org/, acesso em 10/07/2012. Filtros utilizados: Time Frame > 1756 - 1807; Principal place of slave landing > Brazil > Amazonia > Maranhão.

${ }^{195}$ The Trans-Atlantic Slave Trade Database. Disponível em http://www.slavevoyages.org/, acesso em 10/07/2012. Filtros utilizados: Time Frame > 1756 - 1807; Principal place of slave landing > Brazil > Amazonia > Maranhão. Ressalta-se que entre 1756 e 1807 foram introduzidos no Maranhão cerca de 59.064 africanos oriundos não apenas dos Rios da Guiné, como também de Angola e Costa da Mina. Os 35.722 referentes dos Rios da Guiné correspondem a 60\% desse total. 
A tabela demonstra que a entrada de escravos, dos Rios da Guiné, tende a crescer principalmente a partir de meados da década de 1770, com queda razoável no final do século XVIII, principalmente com a volta dos navios negreiros que transportavam de Angola. Como visto é a partir dessa década que a produção de arroz e algodão passa a expandir no Maranhão e a economia de exportação ganha fôlego. Nesse sentido, o gráfico abaixo serve como base para analisar o movimento da produção maranhense em relação com os escravos introduzidos no porto de São Luís, que eram oriundos dos portos da Guiné Portuguesa: ${ }^{196}$

\section{Gráfico XV. Relação entre a produção de arroz e algodão e a entrada de escravos} dos Rios da Guiné no Maranhão (1760-1807)

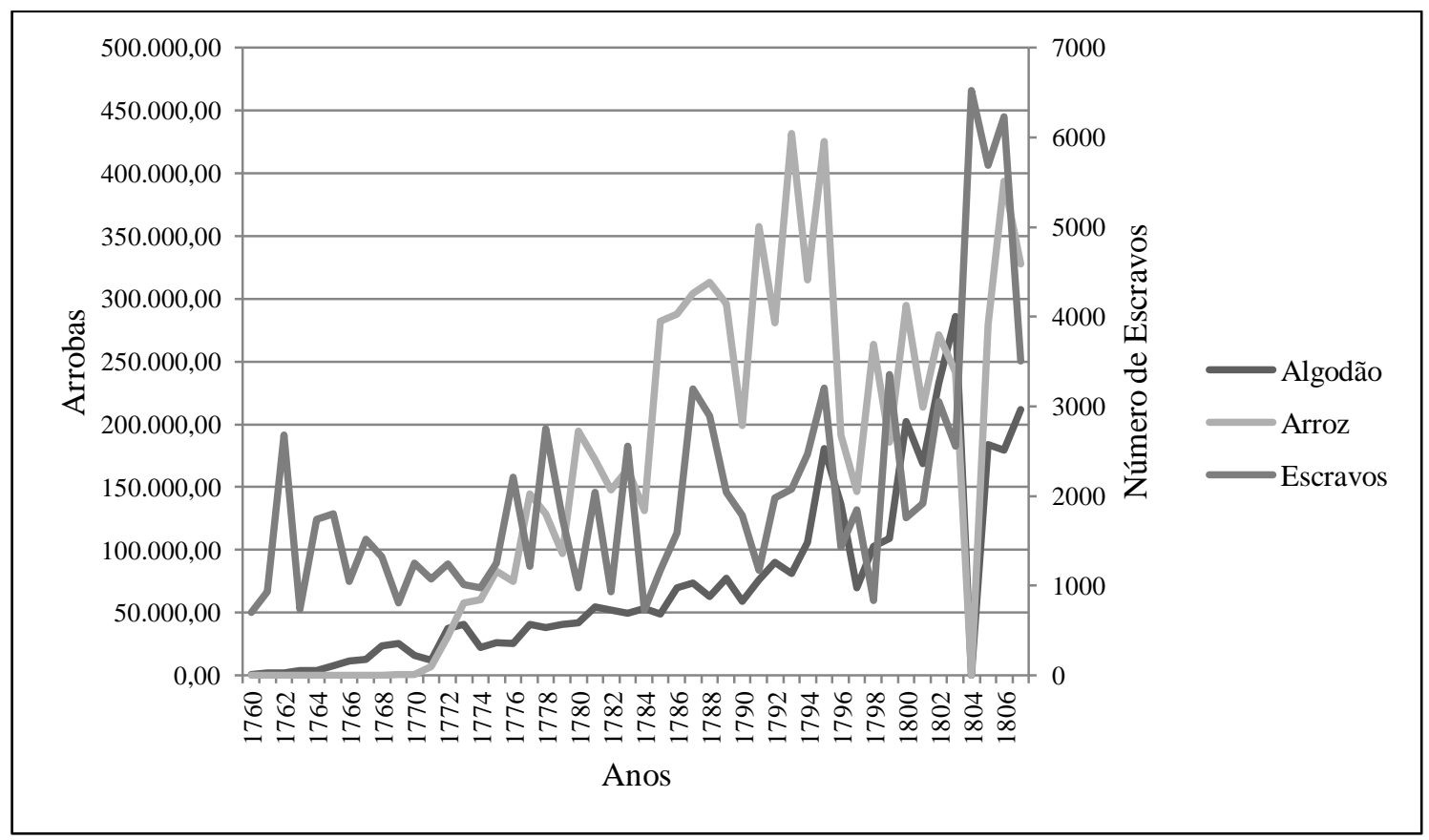

O fato é que existiu uma mudança estrutural na economia maranhense durante a década de 1770. Durante a segunda metade da década de 1750 e toda a década de 1760, o Maranhão assistiu a uma transição: de uma economia estagnada, baseada em uma produção rudimentar de algodão, arroz e tabaco e na extração de algumas drogas na porção em que seu território é coberto pela floresta amazônica utilizando fundamentalmente a mão de obra nativa, para uma economia de exportação de gêneros agrícolas aos moldes da plantation do Estado do Brasil. Um ciclo virtuoso em que o

\footnotetext{
${ }^{196}$ Para o gráfico, utilizamos nossa base de dados montada através de vários documentos tabulados nos documentos avulsos do Pará e do Maranhão. Para consultar a documentação, ver Anexos.
} 
tráfico de escravos estimulava a produção, e ao mesmo tempo em que essa se expandia, aumentava a demanda por mão de obra africana.

Nesse sentido, segundo censo publicado por Dauryl Alden, temos que em 1770, 40\% da população do Maranhão eram de escravos. E essa circunstância de comporem pouco menos da metade da população maranhense na década de 1770 , também vai influenciar diretamente na questão das relações sociais. São Luís do Maranhão até a primeira metade do século era composto basicamente de indígenas, colonos e muito poucos africanos. A mudança no paradigma da colonização na região, proposta pelas políticas pombalinas, modificaram enormemente a sociedade maranhense: de uma sociedade amazônica, para uma sociedade cada vez mais parecida com àquelas encontradas no Estado do Brasil. ${ }^{197}$

Mas não só de atividades agrícolas exportadoras, em que o tráfico de escravos africanos era imprescindível, vivia a economia do Maranhão. Pode-se destacar também a pecuária para a produção de couros e em menor escala a extração de produtos tropicais, sendo as mais importantes o cacau e o gengibre. A pecuária necessitava de pouca mão de obra e os escravos não eram tão necessários: diferente dos campos do sul da colônia, onde os escravos compunham quase $40 \%$ dos vaqueiros, no Maranhão o trabalho era realizado por brancos livres, mas principalmente os indígenas. Bem como, na economia extrativa do cacau e das drogas do sertão. ${ }^{198}$

Não há remessas de carne para metrópole, o que caracterizaria a produção voltada para o abastecimento interno da colônia. Contudo os couros faziam parte significativa das exportações maranhenses do século XVIII, sendo o terceiro mais importante atrás do algodão e o arroz. Já as remessas de cacau sempre foram fundamentais para a economia amazonense; entretanto, no Maranhão não tinham a mesma relevância que possuíam no Pará. No que diz respeito às drogas do sertão, podese dizer que havia uma grande variedade de produtos extrativos, mas o único que pode atribuir certa importância no grosso das exportações maranhenses era o gengibre. $\mathrm{Na}$ tabela abaixo, procurou-se atribuir um preço médio dos produtos mais relevantes das remessas do Maranhão, para título de comparação: ${ }^{199}$

\footnotetext{
${ }^{198}$ SERRÃO, Joel \& MARQUES, A. H. de Oliveira. Op. Cit. (p. 111-3).

${ }^{199}$ A quantidade dos produtos da Tabela XX está em arrobas, menos a courama que está em unidades. Os preços médios foram calculados com base nos dados da Companhia do Comércio do Grão-Pará e do
} 
Tabela XX. Quantidade e Valores Médios dos Gêneros Maranhenses de Exportação (1760-1807)

\begin{tabular}{|c|c|c|}
\hline Gêneros & Quantidade & Valores \\
\hline Algodão & $3.450 .757,60$ & $18.979: 166 \$ 800,00$ \\
\hline Arroz & $7.798 .535,45$ & $6.238: 828 \$ 360,00$ \\
\hline Courama & 1.357 .197 & $2.130: 022 \$ 200,00$ \\
\hline Gengibre & $65.106,09$ & $55: 340 \$ 176,50$ \\
\hline Cacau & $10.981,01$ & $17: 427 \$ 216,00$ \\
\hline
\end{tabular}

O fato, corroborado pelos números da tabela acima, seria o algodão como o principal produto de exportação da economia maranhense. Os outros principais somados, não chegam à metade das receitas geradas pela fibra herbácea. Outro fator a ser levado em consideração é que juntando os dois principais produtos agrícolas, em que a mão de obra africana se fazia imprescindível - o algodão e o arroz - estes representam $92 \%$ dos valores exportados dos portos de São Luís. O que mais uma vez reforça a mudança da estrutura produtiva maranhense na segunda metade do século XVIII: a entrada de escravos africanos fez com que a economia da capitania tendesse ao crescimento, com a consolidação e expansão das lavouras ao modelo das plantations. $\mathrm{O}$ objetivo agora é verificar se o mesmo caso ocorreu na capitania do Grão-Pará.

\subsection{A Economia Paraense (1756-1807)}

A capitania do Grão-Pará abrigou entre os anos de 1751 e 1772 a capital do Estado do Grão-Pará e Maranhão, situada na cidade de Belém. Foi a cabeça

Maranhão, disponibilizados por António Carreira, para o período entre 1760 e 1778; para o período posterior foram utilizados os dados dos mapas de carga de embarcação, coletados nos Documentos Avulsos do Conselho Ultramarino, digitalizados pelo Projeto Resgate. Para o algodão, foi atribuído o valor médio de $5 \$ 500$ por arroba; para o arroz, o valor de $\$ 800$ por arroba; para o cacau, o valor de $1 \$ 600$ por arroba; para o gengibre, o valor de $\$ 850$ por arroba. Já para a courama foi atribuída os seguintes valores: atanados, $1 \$ 800$ a unidade, sendo exportadas no período 851.032 unidades; vaquetas, $1 \$ 800$ a unidade, sendo exportadas no período 221.681 unidades; por fim, os couros em cabelo, $\$ 700$ a unidade, sendo exportados no período 284.484 unidades. Cf: CARREIRA. Op. Cit. 1988. Passim. 
administrativa da Amazônia, como também onde a Companhia de Comércio mantinha seus principais administradores. Como visto anteriormente, a escolha de Belém como capital do Estado teve muito mais a ver com questões de defesa de fronteiras e da foz do Amazonas, do que logística ou econômica. Quase toda a capitania era coberta por florestas tropicais, com alta taxa de umidade do ar e altos índices pluviométricos durante boa parte do ano. O que, de certa forma, inviabilizou o desenvolvimento de grandes lavouras; junte-se a isso, a falta de uma rota de tráfico de escravos regular e com isso a baixíssima entrada de escravos africanos. ${ }^{200}$

A economia paraense era o carro-chefe da economia amazônica, até pelo menos a primeira metade do século XVIII. Com a falta de lavouras no Maranhão, a economia de exportação amazônica era dependente, quase que exclusivamente, das carregações de cacau, como já apontado no Gráfico X. Este produto extrativo sempre esteve na lista dos principais produtos de exportação. Tanto é que "o valor da exportação paraense viveu dependência das frotas do cacau. ${ }^{, 201}$ E essa predominância se deveu ao fato de que o cacau era o produto mais procurado nos leilões de Lisboa; tinha maior procura do que o arroz, produto considerado de primeira necessidade pela metrópole.

A cultura de cacau já era bem difundida pelas civilizações pré-colombianas, no que hoje conhecemos como México e Peru, e fora introduzido na Europa pelos espanhóis. Nos primórdios da colonização portuguesa na Amazônia, foram encontradas as primeiras árvores de cacau silvestre nas margens e nos afluentes do Rio Amazonas. Como todas as atividades extrativas, a preferência para a mão de obra sempre fora dada aos indígenas; tal fato permitiu que a exploração cacaueira ficasse restringida aos jesuítas até finais da década de 1750 , tendo em vista que os indígenas deveriam ser tutelados pelo poder clerical em aldeamentos, o que resultou em diversos conflitos com os colonos e administradores como visto anteriormente. No gráfico abaixo, relaciona-se o valores das exportações de cacau diante dos valores das exportações totais remetidas do porto de Belém: ${ }^{202}$

\footnotetext{
${ }^{200}$ No caso, a opção pelo recorte entre 1756 e 1807 - diferente do caso do Maranhão - é que as séries de exportação para o Grão-Pará estão completas desde 1730, o que possibilita analisar o período desde o início do monopólio da Companhia de Comércio.

${ }^{201}$ DIAS, Manuel Nunes. Op. cit. (p. 287)

${ }^{202}$ Para o gráfico, utilizamos nossa base de dados montada através de vários documentos tabulados nos documentos avulsos do Pará e do Maranhão. Para consultar a documentação, ver Anexos.
} 
Gráfico XVI. Relação entre as Exportações Totais do Grão-Pará e de Cacau (17561807)

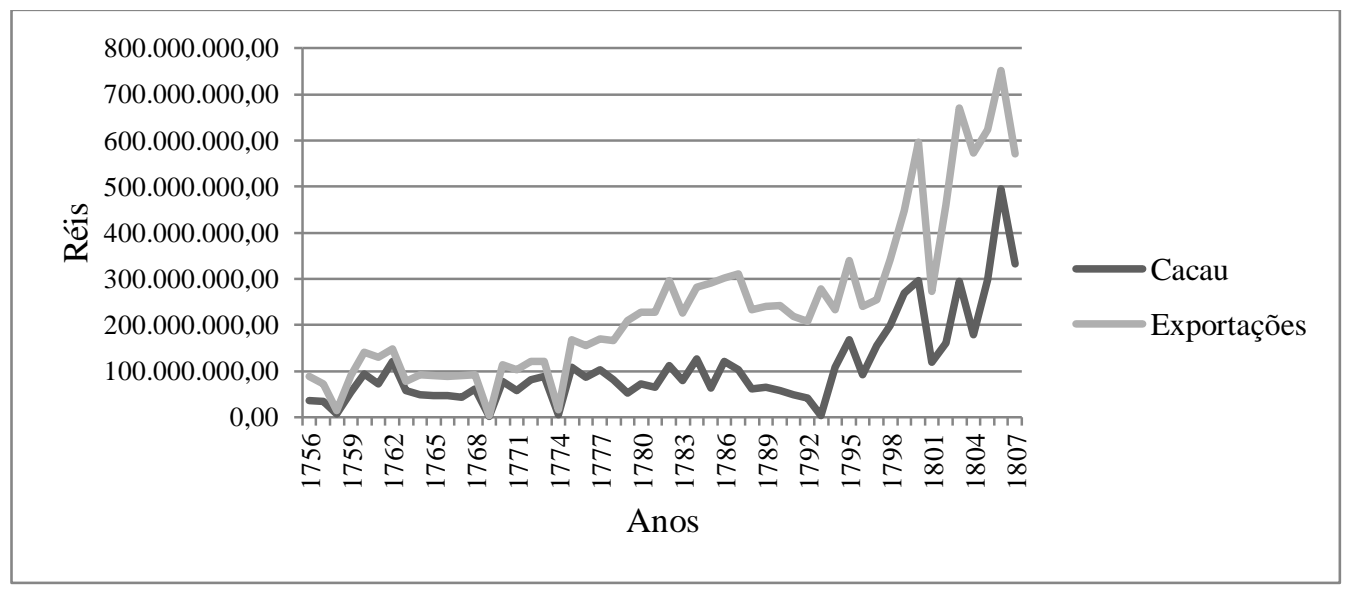

O gráfico aponta que até meados da década de 1770, o cacau representava uma enorme parte nas exportações paraenses. Apesar do descolamento ocorrido percebe-se, contudo, que a linha das remessas totais tende a acompanhar a flutuação das carregações do cacau. Nesse sentido, mesmo que outros produtos comecem a possuir um pouco mais de relevância no conjunto das exportações totais, estas estavam sempre intrinsecamente ligadas as carregações de cacau. Sendo assim, pode-se sugerir que existe uma relação de simbiose entre a economia do Pará e a extração de cacau, o que de certa forma já diferencia a produção em relação ao Maranhão, tanto do ponto de vista produtivo, quanto do social: uma sociedade baseada, mesmo depois da chegada da empresa pombalina, no extrativismo e na coleta, atividades que não necessitavam obrigatoriamente de mão de obra escrava africana.

Quando se analisa o conjunto das exportações paraenses, percebemos outros segmentos com alguma importância na economia de exportação além do cacau: as drogas do sertão (cravo fino, cravo grosso e salsa parrilha) e os couros e seus derivados sempre estiveram na pauta das exportações do Grão-Pará, atividades essas, que assim como o cacau, também não necessitava exclusivamente de escravos africanos; e já nos finais dos anos 1770, a rizicultura e a cotonicultura que passaram por um processo de expansão. Todavia essa produção não deslanchou como no Maranhão, tendo períodos bastante instáveis nos fins das décadas de 1780 e 1790. Também se pode apontar o café como um produto que sempre fez parte das exportações paraenses, mas sem tanta 
importância como os outros gêneros. Para entender a composição das remessas paraenses, segue tabela abaixo: ${ }^{203}$

Tabela XXI. Quantidade e Valores dos Gêneros Paraenses Exportados (1756-1807)

\begin{tabular}{|c|c|c|}
\hline Gêneros & Quantidade & Valores \\
\hline Cacau & $3.144 .623,61$ & $5.722: 989 \$ 475,50$ \\
\hline Arroz & $2.380 .600,12$ & $1.776: 326 \$ 702,70$ \\
\hline Drogas & $4.995 .836,87$ & $1.741: 324 \$ 715,40$ \\
\hline Algodão & $256.313,60$ & $1.516: 240 \$ 162,00$ \\
\hline Couro & $4.150 .309,00$ & $620: 206 \$ 975,00$ \\
\hline Café & $184.050,30$ & $502: 278 \$ 980,80$ \\
\hline
\end{tabular}

O que se percebe com a Tabela XXI, é novamente a proeminência do cacau no conjunto das exportações. No aspecto da quantidade, até são remetidas mais drogas do sertão. Mas ao analisar os valores, temos que o cacau rende quase cinco vezes mais que o arroz, o algodão e as drogas, enquanto equivale em quase dez vezes a courama e mais do que dez as exportações de café. Mais uma vez se corrobora a idéia de simbiose da economia paraense e a extração de cacau. O gráfico abaixo reforça ainda mais a importância o fruto do cacaueiro na composição das exportações remetidas do porto de Belém para Lisboa:

\section{Gráfico XVII. Porcentagem dos Produtos Paraenses Exportados (1756-1807)}

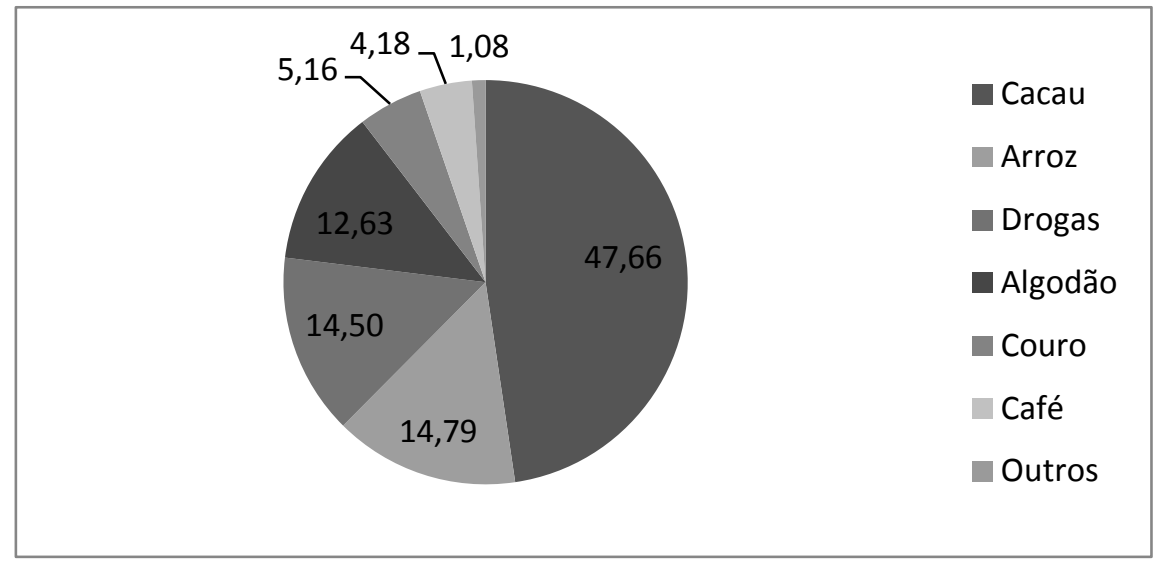

${ }^{203}$ Os valores atribuídos aos produtos contidos na Tabela X, não são valores médios. Como a série de exportações do Grão-Pará está bem completa, os gêneros remetidos já vinham nos mapas de exportação e de carga das embarcações com os valores de cada um dos produtos exportados. Nesse sentido, não foi necessário o cálculo do valor médio, como no caso do Maranhão cuja série estava um pouco comprometida em relação aos valores das mercadorias. 
As remessas de cacau correspondem a cerca de $47 \%$ do valor total das exportações paraenses compreendidas entre os anos de 1756 e 1807. Em outros, que compõe pouco mais de $1 \%$ das exportações, representam as ínfimas remessas de açúcar, aguardente e madeira que também eram despachadas do porto da cidade de Belém. Os dados falam por si só. Contudo, é interessante indagar que mesmo com a Companhia de Comércio monopolizando o tráfico de escravos e o comércio dos produtos amazônicos, o porquê de não haver uma expansão da lavoura no Pará, aos mesmos moldes do que ocorrera no Maranhão.

A explicação pode ser encontrada no próprio tráfico de escravos. A entrada de africanos no Grão-Pará foi bem inferior se comparada ao do Maranhão. Temos que dos já citados 47.877 escravos introduzidos na Amazônia, oriundos dos Rios da Guiné, apenas 12.403 foram destinados ao porto de Belém, no período compreendido entre 1756 e 1807: ou seja, 25,9\% de toda a escravaria vindas de Bissau, Cacheu, Cabo Verde e de outros portos menores da Guiné Portuguesa. Tal fato é corroborado quando se faz a relação entre os escravos introduzidos na Amazônia, e a flutuação da produção agrícola e extrativa da capitania paraense: ${ }^{204}$

\section{Gráfico XVIII- Relação entre Produção Paraense e Entrada de Escravos (1756-}

1807)

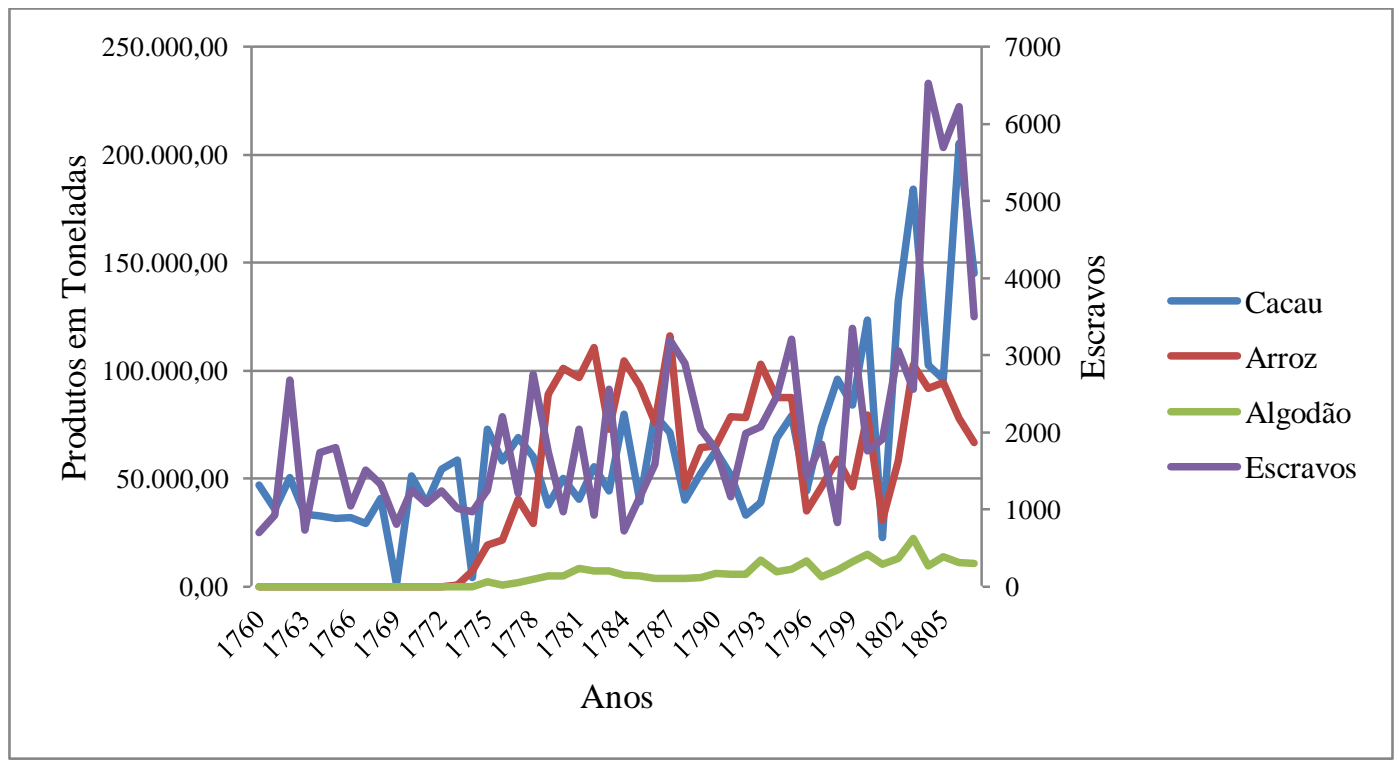

${ }^{204}$ Para o gráfico, utilizamos nossa base de dados montada através de vários documentos tabulados nos documentos avulsos do Pará e do Maranhão do Projeto Resgate. 
O gráfico demonstra que a entrada de escravos não influi diretamente na produção paraense. Apesar de haver alguns picos na produção do arroz e do cacau, esses não demonstram ter uma relação tão intrínseca com a entrada de escravos, como ocorre no caso maranhense. No que diz respeito ao algodão, apesar de suas remessas no quesito financeiro estarem muito próxima das de arroz, sua produção em relação à entrada de mão de obra é ínfima. Quando se observa os dados numéricos referentes à entrada de escravos apenas para o Grão-Pará, o caso da relação menos propínqua existente entre produção e escravaria se evidencia ainda mais e a tabela abaixo exemplifica isso:

Tabela XXII. Escravos Introduzidos no Grão-Pará, oriundos dos Rios da Guiné (1756-1807)

\begin{tabular}{|c|c|}
\hline Qüinqüiênios & Escravos \\
\hline $1756-60$ & 901 \\
\hline $1761-65$ & 1.478 \\
\hline $1766-70$ & 2.109 \\
\hline $1771-75$ & 3.353 \\
\hline $1776-80$ & 1.985 \\
\hline $1781-85$ & 520 \\
\hline $1786-90$ & 972 \\
\hline $1791-95$ & 732 \\
\hline $1796-1800$ & 0 \\
\hline $1801-07$ & 353 \\
\hline TOTAL & $\mathbf{1 2 . 4 0 3}$ \\
\hline
\end{tabular}

Fonte: The Trans-Atlantic Slave Trade Database. Disponível em http://www.slavevoyages.org/, acesso em 10/07/2012. Filtros utilizados: Time Frame > 1756 - 1807; Principal place of slave landing > Brazil > Amazonia > Pará

É nítida e evidente a diferença entre as entradas do Maranhão e do Grão-Pará: comparando a Tabela XIX com a Tabela XXII observa-se que o porto de São Luís recebeu quase o triplo de escravos que recebeu o de Belém. A entrada de africanos na capitania foi tão baixa, que no qüinqüênio compreendido entre os anos de 1796 e 1800 nenhum escravo vindo das feitorias dos Rios da Guiné foi introduzido no porto paraense. É fato que no cômputo geral, levando em conta os escravos de Angola e 
outros portos menos importantes da África, houve peças remetidas. Mas os dados apresentados são sintomáticos em corroborar a diferenciação nos modelos de exploração das duas principais capitanias amazônicas. Fato ainda reforçado, quando se analisa o mesmo censo publicado por Alden: na mesma década de 1770, 26\% da população da capitania do Grão-Pará era de escravos.

A baixa entrada de escravos na capitania do Grão-Pará refletiu na continuidade da organização da produção paraense, nos mesmos moldes do que existia antes da criação da Companhia. Como no extrativismo e na coleta a necessidade de mão de obra africana não se fazia primordial, a demanda por grandes plantéis de escravos oriundos do mercado atlântico era baixa. A produção poderia muito bem se organizar como já o era, antes da Companhia de Comércio: com a utilização de mão de obra indígena, já ambientada e especializada na extração das drogas do sertão e na coleta do cacau nas margens do Amazonas e seus afluentes, desde o final do século XVII. Apesar de algumas remessas relevantes de arroz, essas nunca chegaram ao mesmo patamar visto no Maranhão.

Sendo assim pode-se questionar o porquê dessa situação descrita nos últimos dois tópicos desse capítulo: sendo duas áreas exploradas pela mesma Companhia Geral do Grão-Pará e Maranhão, muito próximas geograficamente e com potenciais produtivos semelhantes, por que a empresa pombalina atuou de maneira diferente em cada uma delas, refletindo diretamente em como ambas as capitanias se estruturaram econômica e socialmente até pelo menos meados do século XIX?

A documentação e a historiografia não respondem a essa pergunta. Nas correspondências da Companhia Geral do Grão-Pará e Maranhão, existentes no Arquivo Nacional da Torre do Tombo e nos documentos avulsos do Conselho Ultramarino digitalizados pelo Projeto Resgate - referentes às capitanias do Grão-Pará e a do Maranhão - não há nenhum menção sobre o porquê dessas escolhas. A pouca bibliografia existente sobre a própria Companhia e a História da Amazônia colonial também não responde essa questão. 
Uma hipótese plausível, nesse sentido, é de que a empresa pombalina simplesmente manteve a estrutura produtiva do cacau já existente desde pelo menos o final do Seiscentos, que já se mostrava de certa forma eficiente para os padrões do período, até porque - como dito anteriormente - o cacau era bastante demandado nas praças mercantis européias. Já no Maranhão, onde não havia se estruturado nenhuma produção que fosse significativa até meados do XVIII, houve a necessidade de se implementar um novo sistema produtivo, baseado nas experiências anteriores das pequenas lavouras de algodão e arroz, já conhecidas pelos nativos. Mas, no momento, essa discussão fica apenas no campo da especulação.

Contudo, para uma exploração em larga escala, esta somente se daria através da introdução regular e em número satisfatório de escravos africanos. Fato que se deu apenas na capitania maranhense, como mostrado no decorrer do capítulo. Nesse sentido, observa-se que a mudança na estrutura da produção ocorrida no Maranhão não ocorreu no Grão-Pará. Enquanto que no Maranhão os dados apontam, sobretudo a partir da década de 1770, para uma mudança expressiva na estrutura produtiva da capitania, o mesmo não é observado no Grão-Pará. Das capitanias amazônicas, o Maranhão foi o que mais se aproximou do sistema produtivo de plantations, se descolando do que sempre caracterizou a economia amazônica até meados do Setecentos, enquanto o GrãoPará continuou a subsistir economicamente da mesma maneira: extrativismo e coleta, baseados na mão de obra nativa.

Sendo assim, no decorrer do capítulo observamos como as diretrizes políticas e econômicas do Gabinete Josefino para Amazônia permitiu uma entrada regular de escravos e uma expansão da produção, que permitiu a integração definitiva da economia Amazônica na dinâmica da economia atlântica portuguesa. Mesmo sendo uma economia ainda marginal em comparação com o Estado do Brasil, possibilitou a diversificação dos gêneros americanos introduzidos em Lisboa. E mesmo atuando de maneira distinta na organização da produção das capitanias do Grão Pará e do Maranhão ficou evidente que o ponto de viragem da economia Amazônica, foi a criação da Companhia Geral do Comércio do Grão-Pará e Maranhão. 


\section{CONSIDERAÇÕES FINAIS}

Diante do que expomos em nosso trabalho, podemos apontar para uma relação de interdependência política e econômica entre Cabo Verde e dos Rios da Guiné. A presença portuguesa na Costa da Guiné - mais especificamente nas praças de Bissau e Cacheu - só foi possível porque Portugal empreendeu a colonização, mesmo que frágil, no arquipélago. O surgimento das feitorias de Bissau e Cacheu teve início, com colonos caboverdianos no século XVI, que passaram a se engajar no comércio com a Costa, sobretudo no que diz respeito ao tráfico de escravos. Essa experiência resultou em um processo de miscigenação: um "novo homem" surge desse processo, em que assimilou características de ambas às culturas: portuguesa e africana. O mestiço - chamado pela historiografia de crioulos ou afro-portugueses - era peça fundamental para o negócio negreiro, a partir do momento que se imbuiu no comércio realizado nas feiras do sertão africano.

Apesar de demonstramos a frágil economia de Cabo Verde, assolada de tempos em tempos por longos períodos de seca que dizimava boa parte da população das ilhas e punha em risco a ocupação por parte de Portugal, podemos afirmar que a colonização do arquipélago assegurou aos traficantes portugueses o acesso, quase que exclusivo, da produção dos têxteis caboverdianos. Mostramos, contudo, que a importância dos têxteis para a realização do tráfico, sugerida pela historiografia e documentação, deve ser relativizada; entretanto, apesar de custear apenas $20 \%$ dos escravos comprados em Bissau e Cacheu, não devemos ignorar sua importância na composição do banzo: os panos do arquipélago garantiam vantagem aos comerciantes lusitanos, a partir do momento que possuía boa aceitação do mercado nos Rios da Guiné.

Nesse sentido, podemos argumentar que Portugal garantiu o mercado de Bissau e Cacheu pela soma de várias circunstâncias que lhe foram favoráveis: a primeira delas foi à colonização do arquipélago de Cabo Verde, que fora a ponta de lança para a criação das feitorias nos Rios da Guiné; em segundo lugar, a comunidade mestiça identificada com a cultura portuguesa, e que tinha certo controle do comércio de escravos nas feiras do sertão; em terceiro lugar, o acesso aos têxteis caboverdianos, que apesar de relativizada sua importância, ainda assim era importante para a manutenção do negócio. Outro ponto, que merece ser destacado, são as relações e alianças 
estabelecidas com régulos africanos, que diminuía - mas não extinguia - o acesso de comerciantes estrangeiros nas feitorias portuguesas na Guiné.

Nesse sentido, podemos sugerir que Cabo Verde e os Rios da Guiné formavam um complexo escravista. Este trabalho mostrou a existência de uma relação de interdependência entre ambas as regiões. Sendo assim, podemos assegurar que o arquipélago era o vértice desse complexo. De suas ilhas saíam, além dos têxteis, mantimentos e até mesmo homens para a defesa das feitorias. Era o centro administrativo onde ficavam governadores e provedores, que tinham por objetivo tentar gerir esse complicado espaço lusitano em África. Os rios de Guiné, mais especificamente as feitorias de Bissau e Cacheu, eram as bases: era o que sustentava o complexo, pois eram de seus portos que saíam o produto mais importante que os portugueses buscavam em África: a escravatura.

Sem uma oferta de escravos regular, não haveria interesse em despender esforços - mesmo que limitado - para manter a presença portuguesa na região. Com isso, Portugal resolveria um dos pontos centrais da política pombalina: a introdução de escravos na Amazônia, para o desenvolvimento de uma produção agropecuária, bem como na sua (re)ocupação e (re)colonização. Nesse sentido o tráfico foi fundamental, pois além dele próprio garantir lucro, resultava no aumento da produção de gêneros, no crescimento dos dízimos e no incremento do comércio.Sendo assim, a política do Gabinete Josefino foi de conectar a Amazônia com os Rios da Guiné: ao mesmo tempo em que estimulava a economia amazônica, reafirmava a possessão portuguesa do território africano, que interessava a Inglaterra e também a França e Holanda. Estabeleceu-se então o que Rafael Chambouleyron chama de uma conexão no Atlântico Equatorial $^{205}$.

Esta conexão garantiu a entrada regular de mão-de-obra nas capitanias amazônicas, estimulando o cultivo de arroz e algodão, bem como a coleta/extração de cacau e outras drogas do sertão. Isso, sem esquecer, do incremento na pecuária tendo em vista as grandes remessas de courama. Portugal, ao mesmo tempo em que procurava garantir a posse de duas áreas periféricas de seus domínios ultramarinos, conseguiu

${ }^{205}$ CHAMBOULEYRON, Rafael. Escravos do Atlântico equatorial: tráfico negreiro para o Estado do Maranhão e Pará (século XVII e início do século XVIII). in: Revista Brasileira de História. vol. 26, nº 52. ANPUH: São Paulo, 2006. (p. 95) 
integrara Amazônia ao Reino por intermédio do mercado africano de escravos ${ }^{206}$. A Coroa Portuguesa tinha o intuito de consolidar a ocupação do território amazônico, visto como estratégico desde a União Ibérica e, o estabelecimento das relações entre os Rios da Guiné com a Amazônia, foi crucial: demonstramos que sim, a entrada regular de escravos oriundos de Bissau e Cacheu nos portos amazônicos, que se consolidou apenas com a criação da Companhia de Comércio, expandiu a economia amazônica.

De fato, essa expansão precisa ser entendida em um contexto periférico. A entrada de escravos e as remessas de gêneros amazônicos, jamais alcançariam os mesmos números do Estado do Brasil. No entanto, ao conectar as duas margens do Atlântico Equatorial, Portugal garantiu sua posse nos territórios amazônicos ao mesmo tempo em que garantia a diversificação de gêneros oriundos dessa nova configuração: além dos já referidos arroz, algodão e cacau produzidos no Maranhão e Grão-Pará, ainda contava com remessas de erva urzela, que tinha bastante demanda no mercado europeu, e que se configurou como principal produto de exportação de Cabo Verde; além das remessas de milho, identificadas por nós na virada para o século XIX.

Pensamos que, nesse sentido, conseguimos responder nosso questionamento inicial de como se organizou o tráfico adotado nos Rios da Guiné no período estudado. Entendemos que, além disso, o mérito do trabalho esteve em dialogar com os novos estudos sobre o tráfico de escravos. Acreditamos que nossa pesquisa conseguiu demonstrar que o comércio negreiro se adequava e se organizava mediante as especificidades de cada região: além das demandas econômicas, vimos que as relações sociais - e a maneira como a sociedade dos Rios da Guiné se estruturou - são pontos fundamentais para entender como o negócio funcionava. Nesse sentido, consideramos que não podemos falar de modelo de tráfico, mas sim de vários modelos de tráfico, que se estruturavam conforme as características específicas das regiões em que funcionavam.

\footnotetext{
${ }^{206}$ CHAMBOULEYRON. Op. Cit. (p.101)
} 
FONTES E BIBLIOGRAFIA

1. FONTES

\subsection{Fontes Manuscritas}

\section{Arquivo Histórico Ultramarino - Lisboa}

- DOCUMENTOS AVULSOS

- Documentos Avulsos de Cabo Verde (1701-1808)

Caixas 9 a 58-A, com aproximadamente 3.400 documentos.

Cota: AHU_CU_024

- Documentos Avulsos de Guiné (1696-1809)

Caixas 4 a 19, com aproximadamente 1.300 documentos.

Cota: AHU_CU_049

Arquivo Nacional da Torre do Tombo - Lisboa

- JUNTA DE LISBOA

Série: Copiadores

Cartas para Cacheu e Bissau

Microfilme 7263

\section{- CONDE DE LINHARES}

Maço 45, Documento 6

Informações sobre o estabelecimento de Bissau e Cacheu

- JUNTA DO COMÉRCIO

Série: Balança Geral do Comércio de Portugal (1796-1807)

- JUNTA DO COMÉRCIO

Maço 10, Caixa 38

Maço 62, Caixa 202

Maço 62, Caixa 203

Arquivo do Tribunal de Contas - Lisboa

\section{- ERÁRIO RÉGIO}

- Livros 4154 e 4155 (1762-1816). Livros Mestre da Contadoria Geral da África Ocidental, do Maranhão e das Comarcas do Território da Relação da Baía e Governos que nele se compreendem.

- Livro 4205 (1792-1803). Livro de contas correntes do Real Contrato da Urzela. 
- Livros 4207 e 4208 (1778-1833). Livro de registro de cartas e provisões expedidas para Cabo Verde e Guiné.

- Livro 4209 (1782-1803). Livro de lembranças dos pagamentos feitos no Real Erário pertencente às ilhas de Cabo Verde e Bissau.

- Livro 4210 (1781-1807). Livro de registro de letras sacadas em Cabo Verde, Bissau e Cacheu sobre p Tesoureiro Mór do Real Erário.

- Livro 4253 (1749-1807). Livro de Registro das condições dos contratos reais da repartição da África Ocidental.

\section{Biblioteca Nacional de Lisboa}

- MANUSCRITOS 224.

- Microfilme FR 128. Rolo 1. Documentos 1 a 210.

- Microfilme FR 128. Rolo 2. Documentos 211 a 446.

- Microfilme FR 128. Rolo 3. Documentos 447 a 475.

\section{Projeto Resgate Barão de Rio Branco}

\section{- DOCUMENTOS AVULSOS}

- Documentos Avulsos da capitania do Grão-Pará (Cópia Digital)

- Documentos Avulsos da capitania do Maranhão (Cópia Digital)

\subsection{Fontes Digitais}

- The Trans Atlantic Slave Trade Database

Registro de entrada e saída das embarcações dos portos metropolitanos e coloniais

Disponível em slavevoyages.org

\subsection{Fontes Impressas}

ALMADA, André Álvares d'. Tratado Breve dos Rios de Guiné. Lisboa: Ed. Luís Silveira, 1946.

ANDRADE, Bernardino António Álvares. Planta da Praça de Bissau e suas Adjacentes. Academia Portuguesa de História: Lisboa, 1952.

ARAÚJO, Antônio José da Costa. Relação da Viagem da Fragata "Nossa Senhora da Estrela" à Bissau em 1753. Lisboa: Academia Portuguesa de História, 1995.

BARRETO, João. História da Guiné. Lisboa: Editado pelo autor, 1938.

BERRÊDO, António Pereira. Anais históricos do Maranhão. Florença: Tipografia Barbéra, 1905.

DUARTE, Fausto. Os capitães-mores das praças da Guiné. In: Boletim cultural da Guiné Portuguesa. - Vol. VI, n²1, 1951.

GAIOSO, Raimundo José de Sousa. Compêndio Histórico Político dos Princípios da Lavoura do Maranhão. Rio de Janeiro: LMI, 1970.

MENDONÇA, Marcos Carneiro. A Amazônia na Era Pombalina. Brasília: Ed. Senado Federal, 2005. 3 Volumes. 
SARAIVA, José Mendes da Cunha. A Fortaleza de Bissau e a Companhia do Grão-Pará e Maranhão. Publicações do Arquivo Histórico do Ministério das Finanças: Lisboa, 1947.

VIVEIROS, Jerônimo. História do Comércio do Maranhão. São Luís: AML, 1954.

\section{BIBLIOGRAFIA}

LOPES, Gustavo Acioli. Negócio da Costa Mina e Comércio Atlântico - tabaco, açúcar, ouro e tráfico de escravo: Pernambuco (1654-1760). São Paulo: USP, 2008 - tese de doutoramento.

LOPES, Gustavo Acioli \& MENZ, Maximiliano M. Resgate e Mercadorias: uma análise comparadado Tráfico Luso-Brasileiro de Escravos em Angola e na Costa da Mina (Século XVIII). In: Afro-Ásia, núm. 37, 2008.

LOPES, Gustavo Acioli \& MENZ, Maximiliano M. Tráfico e Historiografia: notas e propostas para o estudo do comércio luso-brasileiro de escravos (sec. XVII-XVIII). 2008 (working paper).

ALENCASTRO, Luiz Felipe de. O Trato dos Viventes: formação do Brasil no Atlântico Sul. São Paulo: Companhia das Letras, 2000.

ANDRADE, Maria Carlota das Neves Barbosa. A Ocupação Portuguesa dos Rios da Guiné e a Concorrência Francesa no Período de 1680 a 1750. Dissertação em Licenciatura em História - Universidade de Lisboa: Lisboa, 1967.

ARRUDA, José Jobson de Andrade. O Brasil no Comércio Colonial. São Paulo: Ática, 1980.

AZEVEDO, José Lúcio. Os Jesuítas no Grão-Pará: suas missões e a colonização. Belém: SECULT, 1999.

AZEVEDO, João Lúcio de. O Marquês de Pombal e a sua época. São Paulo: Alameda, 2004.

BARROSO JÚNIOR, Reinaldo dos Santos. Nas Rotas do Atlântico Equatorial: Tráfico de Escravos Rizicultores da Alta-Guiné para o Maranhão (1770-1800). Dissertação de Mestrado. UFBA: Salvador, 2009.

BETHENCOURT, Francisco \& CURTO, Diogo Ramada. A Expansão Marítima Portuguesa (1400-1800). Edições 70: Lisboa, 2010.

BLACKBURN, Robin. A Construção do Escravismo no Novo Mundo. Rio de Janeiro: Record, 2003.

BOXER, Charles. Império Marítimo Português. São Paulo: Companhia das Letras, 2002.

CARRARA, Ângelo A. \& SANTIRÓ, Ernest S. Historiografia econômica do dízimo agrário na Ibero-América: os casos do Brasil e Nova Espanha, século XVIII. In: Estudos Econômicos. Vol.43; no.1 São Paulo Jan./Mar. 2013.

CARREIRA, Antônio. Panaria Cabo-Verdiana-Guineense: aspectos históricos e sócioeconômicos. Lisboa: Junta de Investigação do Ultramar, 1968.

CARREIRA, Antônio. As Companhias Pombalinas: de Grão Pará e Maranhão e Pernambuco e Paraíba. Lisboa: Presença, 1983. 
CARREIRA, António. Cabo Verde: Formação e Extinção de uma Sociedade Escravocrata (1460-1878). Lisboa: Mem Martins, 1983.

CARREIRA, António. O Tráfico de Escravos nos Rios de Guiné e Ilhas de Cabo Verde (18101850). Junta de Investigações Científicas do Ultramar: Lisboa, 1981.

CARREIRA, Antônio. A Companhia Geral do Grão-Pará e Maranhão. Lisboa: Nacional, 1988. 2 Volumes.

CHAMBOULEYRON, Rafael. Escravos do Atlântico Equatorial: tráfico negreiro para o Estado do Maranhão e Pará (século XVII e início do século XVIII). In: Revista Brasileira de História. São Paulo, v.26, nº 52, 2006. (p. 79-114).

CHAMBOULEYRON, Rafael. Duplicados clamores: Queixas e Rebeliões na Amazônia Colonial (século XVII). Projeto História, São Paulo, n.33, p. 159-178, dez.2006.

CHAMBOUlEYRON, Rafael \& BOMBARDI, Fernanda Aires. Descimentos privados de índios na Amazônia colonial (séculos XVII e XVIII). In: Varia História. Volume 27, $\mathrm{n}^{\circ}$ 46 Belo Horizonte, Julho/Dezembro, 2011.

CURTO, José. Álcool e Escravos. Lisboa, Editora Vulgata, 2002.

DIAS, Manuel Nunes. Fomento e Mercantilismo: a Companhia do Grão-Pará e Maranhão (1755-1778). Belém: Ed. da UFPA, 1970.

DJALÓ, Tcherno. O Mestiço e o Poder: Identidades, Dominações e Resistências na Guiné. Veja: Lisboa, 2012.

DOURADO, José Ribamar \& BOCLIN, Roberto Guimarães. A Indústria do Maranhão: um Novo Ciclo. Brasília: IEL, 2008.

FALCON, Francisco C. \& NOVAIS, Fernando. A Extinção da Escravatura Africana em Portugal no Quadro da Política Econômica Pombalina. In: VI Simpósio Nacional dos Professores Universitários de História. Goiânia, 1971.

FALCON, Francisco José Calazans. A Época Pombalina. São Paulo: Ática, 1982.

FERREIRA, Roquinaldo. "Ilhas Crioulas": o Significado Plural da Mestiçagem Cultural na África Atlântica. Revista de História 155 (2 - 2006), 17-41.

FISCHER, H. E. S. De Methuen a Pombal: o comércio anglo-português de 1700 a 1770. Lisboa: Gradiva, 1971.

FINLEY, Moses. A Economia Antiga. Porto: Afrontamento, 1980.

FLORENTINO Manolo. Em Costas Negras: uma história do tráfico de escravos entre a África e o Rio de Janeiro (séculos XVIII e XIX). Rio de Janeiro: Arquivo Nacional, 1995.

FLORENTINO, Manolo (org.). Tráfico, cativeiro e liberdade: (Rio de Janeiro, séculos XVII$X I X)$. Rio de Janeiro: Civilização brasileira, 2005.

FRANÇA, Eduardo D’Oliveira. Portugal na Época da Restauração. São Paulo: Hucitec, 1997.

GENOVESE, Eugene. A Economia Política da Escravidão. Rio de Janeiro: Pallas, 1976.

GODINHO, Vitorino Magalhães. Ensaios: Sobre a História de Portugal. Lisboa: Sá da Costa, 1968.

GORENDER, Jacob. O Escravismo Colonial. São Paulo: Ática, 1980 
KLEIN, Herbert S. Novas Interpretações do Tráfico de Escravos do Atlântico. In: Revista de História. São Paulo, no 120, 1989. (p. 3-25)

LOBBAN JR, Richard A. \& MENDY, Peter Karibe. Historical Dictionary of the Republic of Guinea Bissau. The Rowman \& Littlefield Publishing: Plymouth, 2013.

LOPES, Edmundo Correia. A Escravatura: Subsídios para a sua História. Lisboa: Antígona, 1944.

LOVEJOY, Paul. A Escravidão na África: uma história de suas transformações: Rio de Janeiro: Civilização Brasileira: 2002.

MAGALHÃES, Joaquim Romero. O açúcar nas ilhas portuguesas do Atlântico - séculos XV e $X V I$.

MAGALHÃES, Joaquim Romero. Labirintos Brasileiros. São Paulo: Alameda, 2011.

MATTOSO, José. (org.). História de Portugal: no alvorecer da Modernidade. Lisboa: Estampa, 1993.

MATTOSO, José. (org.) História de Portugal: o Antigo Regime (1620-1807). Lisboa: Estampa, 1992.

MAXWELL, Kenneth. Marques de Pombal: paradoxo do iluminismo. Rio de Janeiro: Paz e Terra, 1997.

MAXWELL, Kenneth. Chocolate, Piratas e outros Malandros. São Paulo: Paz e Terra, 1999.

MELO, Márcia Eliane Alves de Souza e. O Regimento das Missões: Poder e Negociação na Amazônia Portuguesa. In: Clio - Série Revista de Pesquisa Histórica - N. 27-1, 2009.

MENZ, Maximiliano M. As Geometrias do Tráfico: o Comércio Metropolitano e o Tráfico de Escravos em Angola (1796-1807). Revista de História (USP), v. 166, p. 185-222, 2012.

MOTA, Thiago Henrique. A Outra Cor de Mafamede: aspectos do islamismo da Guiné em três narrativas Luso-Africanas (1594-1625). Rio de Janeiro: Universidade Federal Fluminense, 2014.

NIANE, Djibril T. (org). História Geral da África - Vol. IV. Brasília: UNESCO, 2010.

NOVAIS, Fernando. Portugal e o Brasil na Crise do Antigo Sistema Colonial. São Paulo: Hucitec, 1995.

NOYA PINTO, Virgílio. O ouro brasileiro e o comércio anglo-português. São Paulo: Ed. Nacional, 1979.

OGOT, Bethwell A. (org). História Geral da África - Vol. V. Brasília: UNESCO, 2010.

PRADO Jr., Caio. Formação do Brasil Contemporâneo. São Paulo: Brasiliense, 1986.

PORRO, Antônio. As crônicas do Rio Amazonas. Petrópolis: Vozes, 1992

RODNEY, Walter. A History of the Guinea Coast (1545-1800). Oxford University Press: London, 1970.

SANTOS, Maria Emília Madeira. História Geral de Cabo Verde. Lisboa: IICT/INCCV, 1995. 3 Volumes. 
SANTOS, Fabiano Vilaça dos. O Governo das Conquistas do Norte: Trajetórias Administrativas no Estado do Grão-Pará e Maranhão (1751-1780). São Paulo: Annablume, 2011.

SERRÃO, Joel \& MARQUES, Oliveira. O Império Luso-brasileiro (1762-1750). Lisboa: Estampa, 1986.

SERRÃO, Joel \& MARQUES, Oliveira. O Império Luso-brasileiro (1750-1808). Lisboa: Estampa, 1986.

SOARES, Fernandes. Dicionário Moderno Ilustrado. Cograe: São Paulo, 1959.

SOUZA, James O. A Mão de Obra Indígena na Amazônia Colonial. In: Em Tempos de Histórias. $\mathrm{n}^{\circ}$ 06, 2002.

TENGARRINHA, José. História de Portugal. São Paulo: EDUSC / Ed. UNESP, 2001.

VERGER, Pierre. Fluxo e refluxo: do tráfico de escravos entre o Golfo do Benin e a Bahia de Todos os Santos. Salvador: Corrupio, 2002.

WALLERSTEIN, Immanuel. El Moderno Sistema Mundial. Buenos Aires: Siglo Veintiuno, 2003.

WILIAMS, Eric. Capitalismo e Escravidão. Rio de Janeiro: Editora Americana, 1975.

s/a. Manual Compacto de Geografia do Brasil. São Paulo: Ridel, 2010. 